U.S. Department of the Interior

U.S. Geological Survey

\title{
Potential Effects of Structural Controls and Street Sweeping on Stormwater Loads to the Lower Charles River, Massachusetts
}

Water-Resources Investigations Report 02-4220

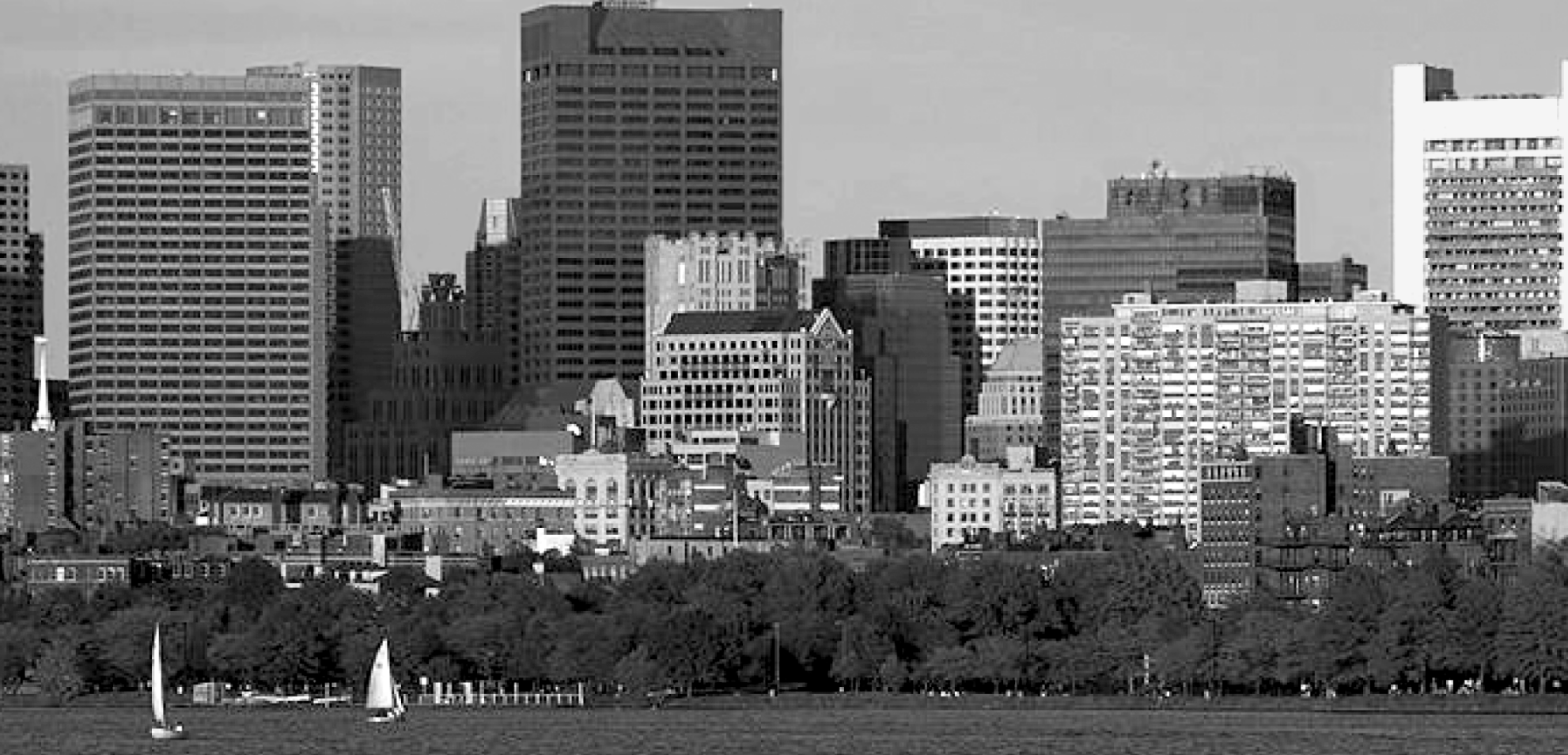

In cooperation with the

U.S. ENVIRONMENTAL PROTECTION AGENCY, the

MASSACHUSETTS DEPARTMENT OFENVIRONMENTALPROTEGTION, and the MASSACHUSETTS WATER RESOUREES AUTHORITY

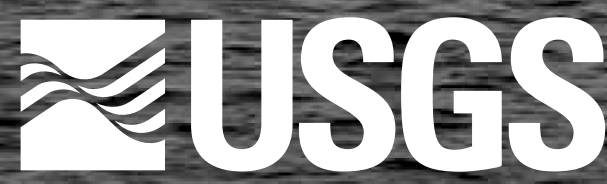

science for a changing world 
Cover photo: View of the lower Charles River looking toward the Boston city skyline

Courtesy of: Philip Greenspun http://philip.greenspun.com 
U.S. Department of the Interior

U.S. Geological Survey

\section{Potential Effects of Structural Controls and Street Sweeping on Stormwater Loads to the Lower Charles River, Massachusetts}

By PHILLIP J. ZARRIELLO, ROBERT F. BREAULT, and PETER K. WEISKEL

Water-Resources Investigations Report 02-4220

In cooperation with the

U.S. ENVIRONMENTAL PROTECTION AGENCY, the

MASSACHUSETTS DEPARTMENT OF ENVIRONMENTAL PROTECTION, and the MASSACHUSETTS WATER RESOURCES AUTHORITY 


\section{U.S. DEPARTMENT OF THE INTERIOR \\ GALE A. NORTON, Secretary}

U.S. GEOLOGICAL SURVEY

Charles G. Groat, Director

The use of trade or product names in this report is for identification purposes only and does not constitute endorsement by the U.S. Government.

For additional information write to:

Chief, Massachusetts-Rhode Island District U.S. Geological Survey 10 Bearfoot Road

Northborough, MA 01532

or visit our Web site at

http://ma.water.usgs.gov
Copies of this report can be purchased from:

U.S. Geological Survey

Branch of Information Services

Box 25286

Denver, CO 80225-0286 


\section{CONTENTS}

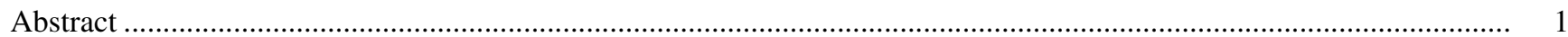

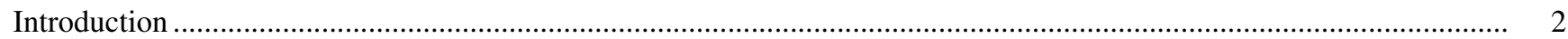

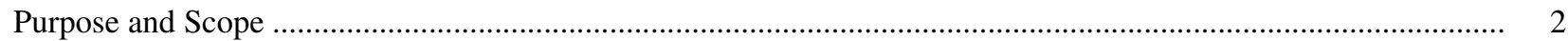

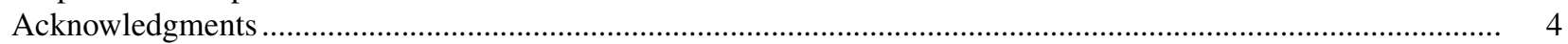

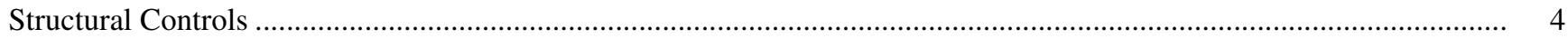

Removal Efficiencies..............................................................................................................................

Estimated Contaminant-Load Removal in the Village Brook Subbasin .............................................................. 7

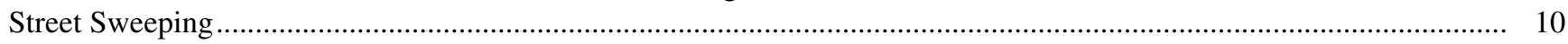

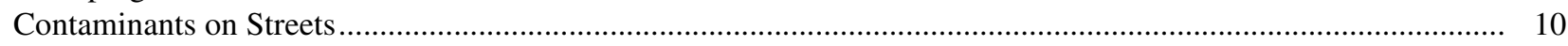

Street Sweeping as a Water-Quality-Management Practice.......................................................................... 12

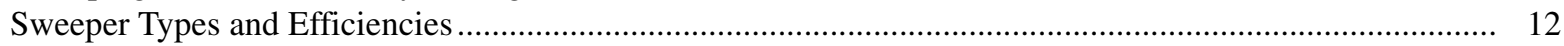

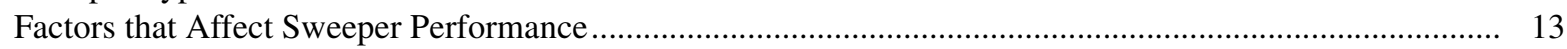

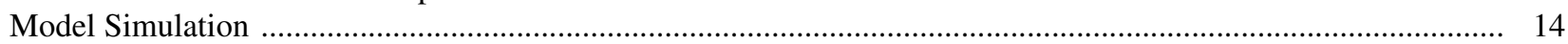

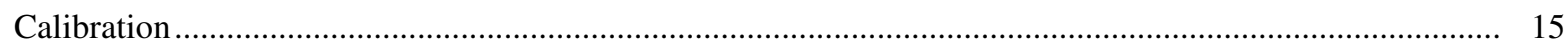

Sweeping Efficiencies and Frequencies Evaluated …......................................................................... 19

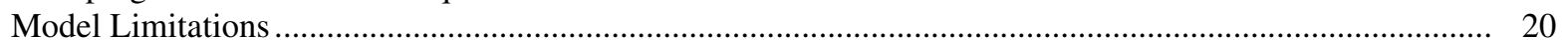

Sensitivity Analysis .................................................................................................................... 22

Simulated Contaminant Removal by Street Sweeping .................................................................................. 23

Calibrated-Model Load Removals ................................................................................................. 23

Alternative-Model Load Removals .......................................................................................................... 24

Potential Effects of Structural Controls and Street Sweeping on Loads to the Lower Charles River ............................... 26

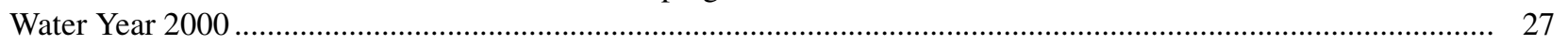

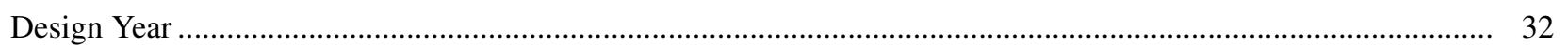

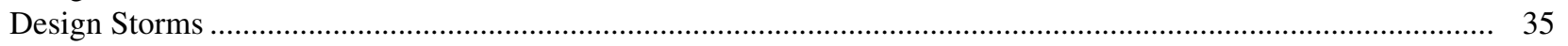

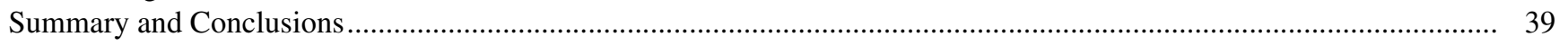

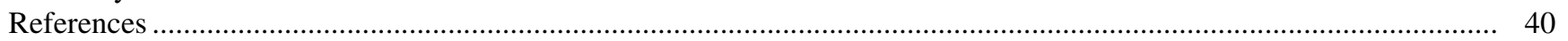

\section{FIGURES}

1. Map showing principal geographic features, precipitation stations, and subbasins of the lower Charles River Watershed, Massachusetts.

2. Box plot showing distribution of constituent removal efficiencies for structural controls, summarized by control type

3. Bar graphs comparing $(A)$ land use and $(B)$ road types in the lower Charles River Watershed and the Village Brook Subbasin .

4. Scatter plot showing relation of simulated constituent loads to measured loads for eight sampled storms between January 10 and July 27, 2000, at the single-family land-use subbasin, lower Charles

River Watershed

5-9. Line graphs showing:

5. Suspended-solids buildup on streets simulated by the Michaelis-Menton method with and without street sweeping at two sweeper efficiencies and 2-day sweeping intervals by the $(A)$ Stormwater Management Model and $(B)$ an adjusted buildup rate corrected to the load that remains after sweeping....

6. Schematic representation of the percent load removed by street sweeping at 2-day intervals when calculated by the Stormwater Management Model and by a buildup rate adjusted for the load remaining after sweeping

7. Sensitivity of $(A)$ annual suspended-solids loads and $(B)$ percent load removed by street sweeping to buildup and washoff variable values in the Stormwater Management Model . 
8. Simulated constituent-load removal for various sweeper efficiencies at selected sweeping intervals in the single-family land-use subbasin, lower Charles River Watershed, 2000 water year

9. Estimated percent load reduction for the 2000 water year by street sweeping at various efficiencies and frequencies for the $(A)$ lower Charles River (excludes the loads above Watertown Dam) and $(B)$ the entire Charles River Watershed (estimated by the street density ratio).

10. Bar graph showing constituent loads from non-combined-sewer-overflow sources from major subbasins, and estimated load reductions by hypothetical structural controls and street sweeping, lower Charles River Watershed, 2000 water year.

11. Box plots and line graphs showing distribution of rainfall and antecedent storm characteristics for the 2000 water year, design year, and 1970-95 period, lower Charles River Watershed.....

12. Bar graphs showing estimated 3-month and 1-year design-storm loads from non-combined-seweroverflow sources from each of the major subbasins and estimated load reductions by hypothetical structural controls and street sweeping for $(A)$ suspended solids and total lead loads and $(B)$ fecal coliform and total phosphorus

\section{TABLES}

1. Categories of structural-control types, their characteristics, and the major physical or chemical processes that affect water quality.....

2. Inventory of structural controls identified by the Center for Watershed Protection for the Village Brook Subbasin, lower Charles River Watershed

3. Estimated removal efficiencies in stormwater loads and total loads by hypothetical structural controls in the Village Brook Subbasin, lower Charles River Watershed.

. Reported and simulated constituent loads for the single-family land-use subbasin, 2000 water year, lower Charles River Watershed.....

. Calibrated Stormwater Management Model variable values for constituent buildup and washoff for the single-family land-use subbasin, lower Charles River Watershed.

. Measured and simulated storm runoff and constituent loads for sampled storms in the single-family land-use subbasin, lower Charles River Watershed

. Efficiencies of street sweepers simulated for removing selected contaminants

8. Measured and simulated loads of suspended solids for sampled storms, single-family land-use subbasin, 2000 water year, lower Charles River Watershed ..... once every two days with the calibrated and an alternative Stormwater Management Model in the single-family land-use subbasin, lower Charles River Watershed...

10. Subbasin street length and density, lower Charles River Watershed

11. Street and subbasin contaminant loads used to calculate the weighting factor for estimating potential contaminant removal by street sweeping, 2000 water year, lower Charles River Watershed

12. Estimated range in the percent decrease in annual loads by hypothetical structural controls, lower Charles River Watershed.

13. Simulated percent annual-load reductions to the lower Charles River, Massachusetts, by street sweeping with the highest efficiency sweepers at various sweeping intervals and the $(A)$ calibrated model and $(B)$ an alternative model

14. Percent annual-load reductions by combined hypothetical structural controls and street-sweeping practices, lower Charles River Watershed.

15. Simulated runoff volume for the 2000 water year and the design year, lower Charles River Watershed.............. 35

16. Estimated design-year constituent loads from non-combined-sewer-overflow sources for each of the major subbasins to the lower Charles River. 
CONVERSION FACTORS AND ABBREVIATIONS

CONVERSION FACTORS

\begin{tabular}{rll}
\hline Multiply & By & To obtain \\
\hline acre & 0.405 & hectare \\
cubic foot $\left(\mathrm{ft}^{3}\right)$ & 0.02832 & cubic meter \\
foot $(\mathrm{ft})$ & 0.3048 & meter \\
gram $(\mathrm{g})$ & 0.002205 & pound \\
inch (in.) & 2.54 & centimeter \\
kilogram $(\mathrm{kg})$ & 2.205 & pound \\
metric ton & 1.1025 & ton \\
microns $(\mu \mathrm{m})$ & 0.00003937 & inch \\
mile $(\mathrm{mi})$ & 1.609 & kilometer \\
\hline
\end{tabular}

ABBREVIATIONS

$\begin{array}{ll}\text { AE } & \text { Average error } \\ \text { AVSWP } & \text { Model availability factor } \\ \text { BMP } & \text { best management practice } \\ \text { CFU } & \text { colony forming units } \\ \text { CSO } & \text { combined sewer overflow } \\ \text { CWP } & \text { Center for Watershed Protection } \\ \text { EMC } & \text { event mean concentration } \\ \text { FHWA } & \text { Federal Highway Administration } \\ \text { MADEP } & \text { Massachusetts Department of Environmental Protection } \\ \text { MWRA } & \text { Massachusetts Water Resources Authority } \\ \text { RMSE } & \text { Root mean square error } \\ \text { SWMM } & \text { StormWater Management Model } \\ \text { TCFU } & \text { trillion colony forming units } \\ \text { USEPA } & \text { U.S. Environmental Protection Agency } \\ \text { USGS } & \text { U.S. Geological Survey } \\ \mu \mathrm{g} & \text { micrograms }\end{array}$





\title{
Potential Effects of Structural Controls and Street Sweeping on Stormwater Loads to the Lower Charles River, Massachusetts
}

\author{
By Phillip J. Zarriello, Robert F. Breault, and Peter K. Weiskel
}

\section{Abstract}

The water quality of the lower Charles River is periodically impaired by combined sewer overflows (CSOs) and non-CSO stormwater runoff. This study examined the potential non-CSO load reductions of suspended solids, fecal coliform bacteria, total phosphorus, and total lead that could reasonably be achieved by implementation of stormwater best management practices, including both structural controls and systematic street sweeping. Structural controls were grouped by major physical or chemical process; these included infiltration-filtration (physical separation), biofiltration-bioretention (biological mechanisms), or detention-retention (physical settling). For each of these categories, upper and lower quartiles, median, and average removal efficiencies were compiled from three national databases of structural control performance. Removal efficiencies obtained indicated a wide range of performance. Removal was generally greatest for infiltrationfiltration controls and suspended solids, and least for biofiltration-bioretention controls and fecal coliform bacteria.

Street sweeping has received renewed interest as a water-quality control practice because of reported improvements in sweeper technology and the recognition that opportunities for implementing structural controls are limited in highly urbanized areas. The Stormwater Management Model that was developed by the U.S. Geological Survey for the lower Charles River Watershed was modified to simulate the effects of street sweeping in a single-family land-use basin. Constituent buildup and washoff variable values were calibrated to observed annual and storm-event loads. Once calibrated, the street sweeping model was applied to various permutations of four sweeper efficiencies and six sweeping frequencies that ranged from every day to once every 30 days.

Reduction of constituent loads to the lower Charles River by the combined hypothetical practices of structural controls and street sweeping was estimated for a range of removal efficiencies because of their inherent variability and uncertainty. This range of efficiencies, with upper and lower estimates, provides reasonable bounds on the load that could be removed by the practices examined. The upper estimated load reduction from combined street sweeping and structural controls, as a percentage of the total non-CSO load entering the lower Charles River downstream of Watertown Dam, was 44 percent for suspended solids, 34 percent for total lead, 14 percent for total phosphorus, and 17 percent for fecal coliform bacteria. The lower estimated load reduction from combined street sweeping and structural controls from non-CSO sources downstream of Watertown Dam, was 14 percent for suspended solids, 11 percent for total lead, 4.9 percent for total phosphorus, and 7.5 percent for fecal coliform bacteria. Load reductions by these combined management practices can be a small as 1.4 percent for total phosphorus to about 4 percent for the other constituents if the total load above Watertown Dam is added to the load from below the dam. Although the reductions in stormwater loads to the lower Charles River from the control practices examined appear to be minor, these practices would likely provide water-quality benefits to portions of the 
river during those times that they are most impaired-during and immediately after storms. It should also be recognized that only direct measurements of changes in stormwater loads before and after implementation of control practices can provide definitive evidence of the beneficial effects of these practices on water-quality conditions in the lower Charles River.

\section{INTRODUCTION}

The Charles River downstream of the Watertown Dam (herein referred to as the lower Charles River, fig. 1), is a major recreational and ecological resource for the Boston metropolitan region, including the municipalities of Boston, Cambridge, Newton, Brookline, and Watertown. The U.S. Environmental Protection Agency (USEPA) has described the Charles River as one of the premier urban rivers in America and a crown jewel of the Boston area. Although seriously impaired for decades, the water quality of the lower Charles River has improved substantially in recent years as major sources of contamination, including combined sewer overflows (CSOs), illicit discharges, and upstream sources are controlled or eliminated. At the turn of the $19^{\text {th }}$ century, Pritchett and others (1903) described parts of the lower Charles River as "putrid"; and as recently as 1996, the USEPA State of the New England Environment (U.S. Environmental Protection Agency, 1996) described the river as "becoming notable not for its recreation potential, but for the stench of sewage." In 1996, the USEPA graded the water quality of the lower Charles River at C-; but in more recent years, the USEPA has upgraded the river to a B (U.S. Environmental Protection Agency, 2002). This higher grade reflects the progress made in removing CSO discharges and illicit connections to the storm-sewer system. Further improvements in water quality are now recognized to be more difficult because pollution sources are smaller and more diffuse.

The USEPA has set a goal of achieving "fishable and swimmable" water-quality standards for the lower Charles River by the year 2005. Following storms, the water quality of the river often fails to meet these standards and can even fall below standards for contact recreation, such as boating. The degraded water quality impairs the river's recreational uses and poses potential health risks. A water-quality assessment of the Boston Harbor drainage area by the Massachusetts Water Resources Authority (1994) indicated that stormwater contaminant loads to the lower Charles River were comparable to loads from sewage-associated sources (CSOs and illicit connections). The Massachusetts Water Resources Authority (MWRA) assessment prompted a closer examination of stormwater loads of nutrients, fecal bacteria, and metals to the lower Charles River (Breault and others, 2002). That study indicated that non-CSO stormwater is an appreciable source of contaminants to the river and underscored the need to address urban stormwater runoff if waterquality standards are to be met. Structural and nonstructural management practices can help meet the water-quality objectives for the river, but a better understanding of their potential benefits is needed. In 2001, the U.S. Geological Survey (USGS), in cooperation with the USEPA, MWRA, and Massachusetts Department of Environmental Protection (MADEP), undertook a study to provide information for waterquality managers on the potential reductions of stormwater-contaminant loads to be expected from various structural and nonstructural management practices.

\section{Purpose and Scope}

This report presents an analysis of potential contaminant-load reductions that could be achieved by implementing selected stormwater controls, or Best Management Practices (BMPs), in the lower Charles River Watershed. The BMPs evaluated include three categories of structural controls (filtration-infiltration structures, detention-retention basins, biofiltration systems) and street sweeping. Potential load reductions by structural controls were estimated from contaminantremoval efficiencies reported in three national BMP databases. The potential contaminant removal by street sweeping is presented from simulations made by calibrating a previously developed rainfall-runoff model of the single-family land-use subbasin to buildup and washoff of loads of suspended solids, fecal coliform bacteria, total phosphorus, and total lead. Removal rates by street sweeping were simulated for various sweeper efficiencies and sweeping frequencies. Finally, this report provides estimates of the combined potential load reductions that could be achieved by structural controls and street sweeping for the 2000 water year (October 1, 1999, through September 30, 2000), a "design year" or "typical year", and 3-month and1-year design storms used by the MWRA for facilities planning. 


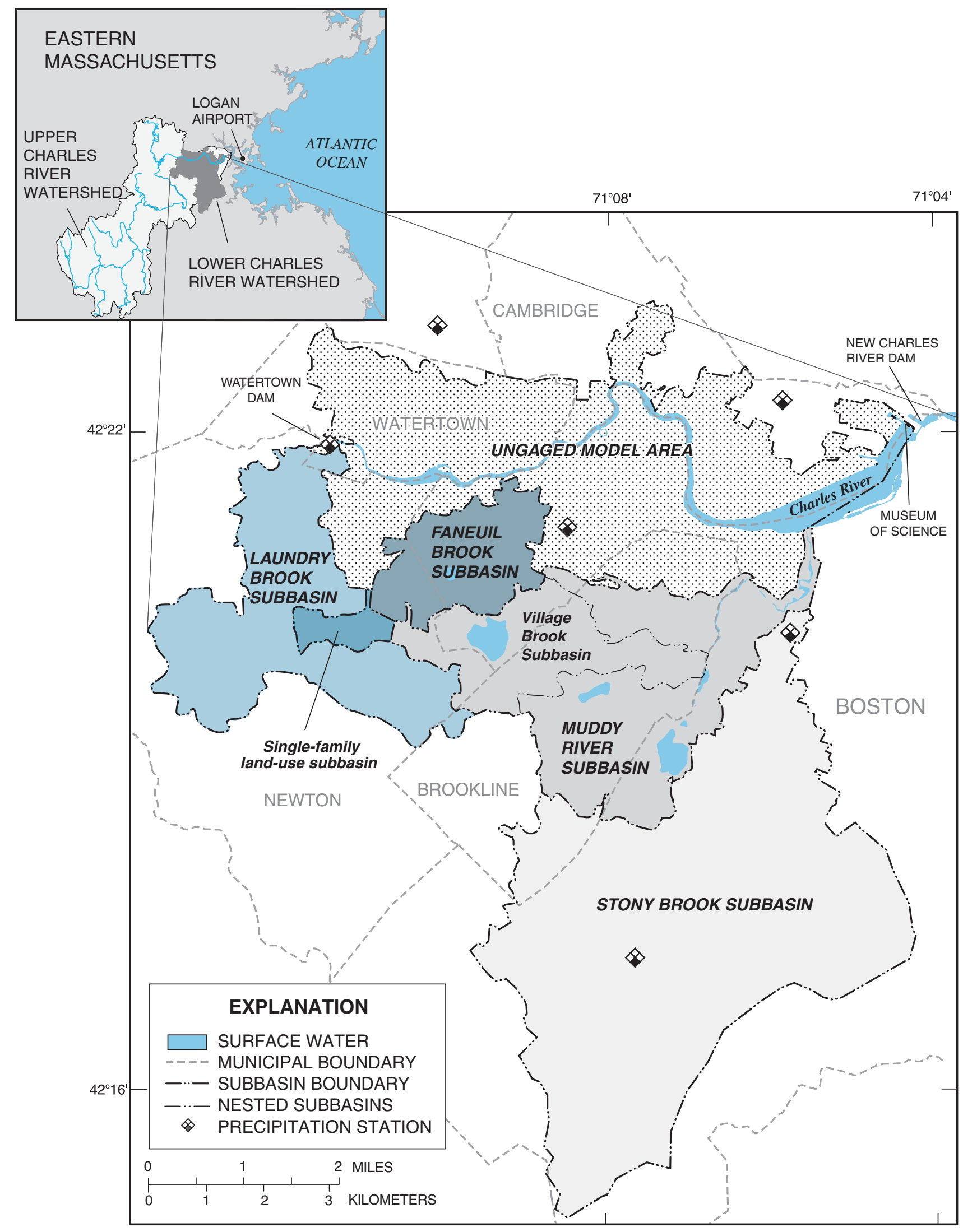

Figure 1. Principal geographic features, precipitation stations, and subbasins of the lower Charles River Watershed, Massachusetts. 


\section{Acknowledgments}

The authors are grateful to Mark Voorhees of USEPA, Lise Marx of MWRA, and Kevin Brander of MADEP, for reviewing the project approach and the report manuscript. Jason Sorenson of the USGS did an initial literature review of contaminant-removal efficiencies associated with structural controls. The national data and methods synthesis on highway runoff and water-quality management controls by the USGS and Federal Highway Administration (FHWA) provided many useful references cited in this study (Granato, 2001).

\section{STRUCTURAL CONTROLS}

The feasibility of implementing structural controls in selected subbasins in the lower Charles River Watershed was investigated by the Center for Watershed Protection (1999). The Center for Watershed Protection (CWP) selected subbasins that represent a cross-section of land uses in the lower Charles River Watershed. For each of these subbasins they identified potential sites and structural controls that could be implemented given the land use and other constraints. The CWP presented a variety of conceptual designs and costs associated with the construction and maintenance of structural controls in their 1999 report to the USEPA; however, it should be recognized that many other types of structural controls, which were not considered in this analysis, particularly proprietary manufactured devices, could provide additional waterquality benefits. The CWP did not specify the removal efficiency or the potential contaminant-load reductions to the lower Charles River that could be realized by the management practices recommended. Without this information, appropriate management decisions may not be made regarding the applicability (planning, design, construction, and maintenance) of structural controls to reduce contaminant loading to the lower Charles River Watershed.

\section{Removal Efficiencies}

Removal efficiencies for three types of structural controls identified for the lower Charles River Watershed were determined by compiling data from three national databases - the National Pollutant Removal Performance Database for Stormwater Best
Management Practices (Brown and Schueler, 1997); Stormwater Best Management Practices in an UltraUrban Setting: Selection and Monitoring (Shoemaker and others, 2000); and the National Stormwater Best Management Practices Database (American Society of Civil Engineers, 2002). Studies cited in these databases that were relevant to this report are cross-referenced by researcher, study location, and date, and include a variety of researchers, municipalities, and state and gov ernment agencies. Ancillary information needed to standardize removal-efficiency data to a common basis, however, was limited. For example, some of the studies reported more than one method to calculate removal efficiency, resulting in different reported efficiency values. Removal efficiencies are typically calculated by comparing contaminant concentrations or loads entering and exiting a structural control. Contaminant concentrations and loads can be instantaneous, eventbased, or yearly, and can be measured or modeled, or both. Furthermore, different values are reported for the same study in different databases; these discrepancies likely stem from different statistical methods used to calculate central tendency in each study. In these cases, the removal efficiency was averaged from the values given in different databases.

Removal efficiencies of structural controls depend on many factors including (1) the type and design; (2) the intrinsic properties of the constituent being removed; (3) the interaction of constituents in stormwater (ions, trace elements, plant material, debris); (4) the fraction of the constituent that is suspended; (5) site characteristics such as soil type, catchment size, land use, percent impervious area, traffic volume, antecedent conditions (Schueler, 1987); (6) storm size and intensity, short circuiting or bypass issues, and retention time; (7) the geochemical environment [those chemical and physical variables that dictate how a contaminant might interact with its environment, including acidity $(\mathrm{pH})$, ionic strength, temperature, and oxidation-reduction potential (Wilde, 1994; Brown and Schueler, 1997; Bricker, 1999)]; (8) monitoring limitations, including study design, field methods, laboratory-analysis techniques, and the number of storms sampled (Breault and Granato, 2000; Tasker and Granato, 2000); and (9) climate and seasonality. In addition to the above factors, the age and maintenance history of a structural control can affect its performance. Most removal-efficiency studies have been conducted in the southeastern and western United States (Shoemaker and others, 2000). The removal 
efficiency of structural controls in the lower Charles River Watershed could be appreciably different than that reported for studies in areas that do not have a distinct non-growing season.

Removal efficiencies of structural controls were grouped by similar major physical or chemical process (table 1). Grouping of similar control types provided a sufficient number of studies for a reasonable evaluation of the central tendency of removal efficiency, given that some controls have been little studied. Controls were grouped by the following categories-infiltration-filtration (physical separation), biofiltration-bioretention (biological mechanisms), or detention-retention (physical settling). Changes in stormwater loads by structural controls identified by CWP were estimated from the upper and lower quartiles, median and average removal efficiencies compiled for each control category (fig. 2). Existing ponds identified by CWP as detention-retention type controls were not considered in this study because their effects are already incorporated into load esti-mates to the lower Charles River. The removal efficiencies obtained are summarized below for total suspended solids, fecal coliform bacteria, total phosphorus, and total lead. A negative efficiency indicates an increase in the contaminant load at the outflow relative to the inflow to the control by remobilization of previously settled contaminants, or measurement error in the load values used to calculate removal efficiency.
Suspended Solids: Removal efficiencies for suspended solids were reported in 93 percent of the 224 studies examined in the national databases and ranged from -170 to nearly 100 percent among control categories. Infiltration-filtration controls generally were most efficient at removing solids (averaged 78 percent) and biofiltration-bioretention controls were generally least efficient (averaged 45 percent). Detention-retention controls removed 62 percent of the suspended solids, on average. Calculated removal efficiencies can be affected by the analytical method used to determine solids loads. Gray and others (2000) found that the sand-sized fraction can be appreciably underreported for suspended solids in samples analyzed from pipetted aliquots (historically referred to as total suspended solids-TSS) relative to samples analyzed from filtered samples (historically referred to as suspended solids concentration-SSC) when the sand fraction represents more than about 25 percent of the total solids present. As a result, studies in which samples were analyzed for SSC can underestimate the removal efficiency of the BMP because the coarse material, which would likely be removed by the BMP, was underreported at the inflow (Bent and others, 2001).

Fecal Coliform Bacteria: Removal efficiencies for fecal coliform bacteria, reported in 28 percent of the 224 studies examined in the databases, ranged from -600 to 99 percent among control categories. The average removal efficiencies for infiltration-filtration and detention-retention type controls were about 32 and 43

Table 1. Categories of structural-control types, their characteristics, and the major physical or chemical processes that affect water quality

[Modified from Shoemaker and others, 2000]

\begin{tabular}{lcll}
\hline Types of controls & Comments & $\begin{array}{c}\text { Major physical or } \\
\text { chemical process }\end{array}$ \\
\hline & $\begin{array}{c}\text { Infiltration trenches, infiltration } \\
\text { basins, underground filters, surface } \\
\text { filters, organic-media filters, porous } \\
\text { pavement }\end{array}$ & $\begin{array}{c}\text { Soil chemical and physical characteristics } \\
\text { affect efficiency; effective suspended } \\
\text { solids removal; regular maintenance } \\
\text { essential to prevent clogging }\end{array}$ & $\begin{array}{c}\text { Infiltration, adsorption, straining, } \\
\text { chemical transformation, } \\
\text { microbial decomposition }\end{array}$ \\
$\begin{array}{c}\text { Bioretention, dry and wet swales, } \\
\text { vegetated filter strips }\end{array}$ & $\begin{array}{c}\text { Soil chemical and physical characteristics } \\
\text { affect efficiency; low cost; easy to install }\end{array}$ & $\begin{array}{c}\text { Biodegradation, precipitation, } \\
\text { infiltration, filtration, } \\
\text { adsorption, precipitation } \\
\text { processes }\end{array}$ \\
$\begin{array}{c}\text { Detention ponds, wetlands/shallow } \\
\text { marsh systems, detention tanks and } \\
\text { valts, oil-grit separators, catch- } \\
\text { basin inserts, manufactured systems }\end{array}$ & $\begin{array}{c}\text { Adequate hydrologic detention time } \\
\text { required; mainly pretreatment }\end{array}$ & $\begin{array}{c}\text { Particulate settling and biological } \\
\text { filtering (wetlands) }\end{array}$ \\
\hline
\end{tabular}



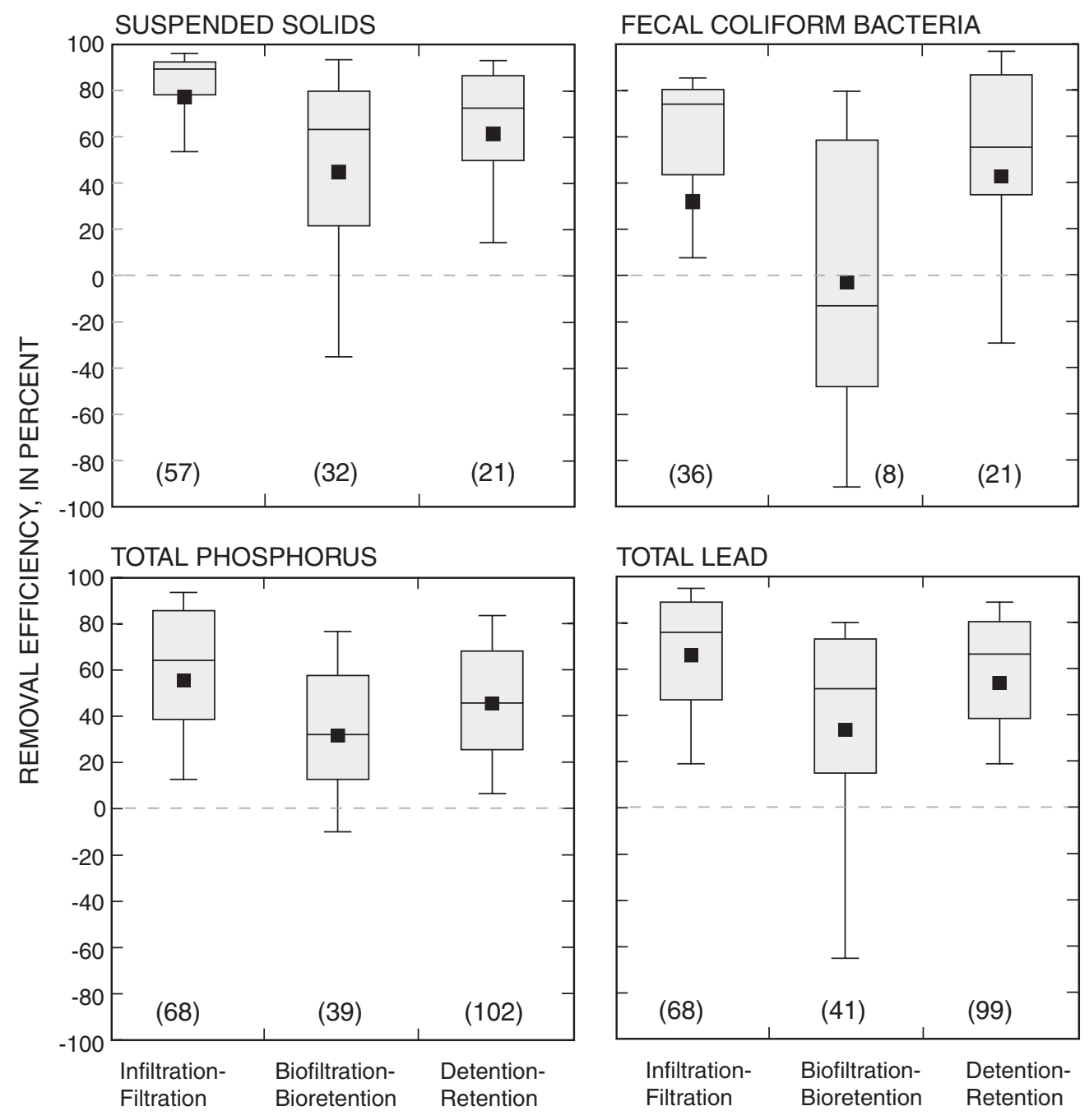

EXPLANATION

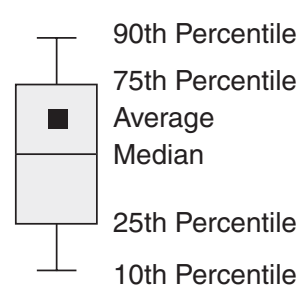

(39) Number of

(39) observations

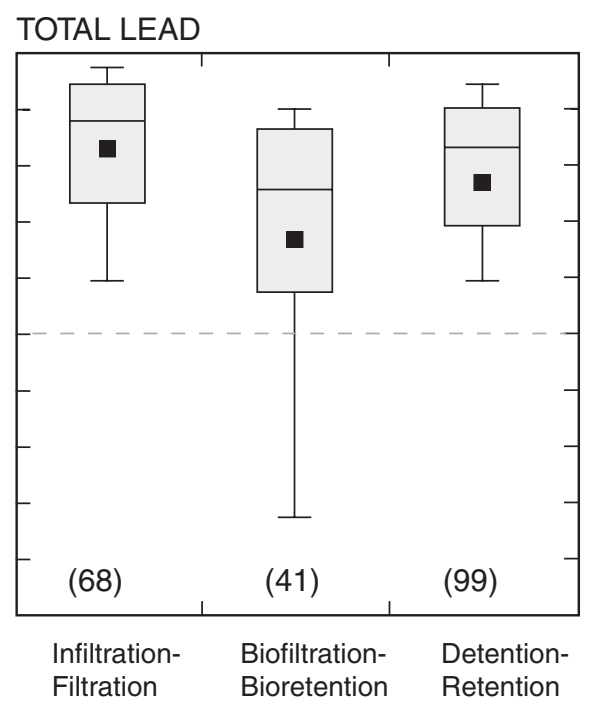

STRUCTURAL CONTROL TYPE

Figure 2. Distribution of constituent removal efficiencies for structural controls, summarized by control type.

percent, respectively, whereas biofiltration-bioretention controls averaged a -3 percent efficiency. Average removal efficiencies for fecal coliform bacteria were lowest compared to the removal efficiencies for the other constituents examined for each control type.

Total Phosphorus: Removal efficiencies for total phosphorus were reported in 93 percent of the 224 studies examined in the national databases and ranged from -162 to 100 percent among control types. In general, removal was most efficient for infiltrationfiltration controls (averaged 56 percent) and least efficient for biofiltration-bioretention controls (averaged 32 percent); detention-retention controls averaged 46 percent removal. The average removal efficiency for total phosphorus was greater than the average for fecal coliform bacteria, but less than the average removal efficiency for suspended solids and total lead for each type of control.

Total Lead: Removal efficiencies for total lead were reported in 70 percent of the 224 studies examined in the national databases; removal efficiencies were similar to those reported for suspended solids 
among control types and ranged from -162 to 100 percent. In general, removal was most efficient for infiltration-filtration controls (averaged 66 percent) and least efficient for biofiltration-bioretention controls (averaged 34 percent); detention-retention controls averaged 54 percent removal. The similarity between the total lead and suspended solids removal is consistent with the known affinity between these constituents (Breault and Granato, 2000).

Average removal efficiencies for each of the constituents examined were generally greatest for infiltration-filtration controls and least for biofiltrationbioretention controls. For each control type, average removal efficiencies were greatest for suspended solids and total lead and least for fecal coliform bacteria and total phosphorus. In general, the average removal efficiency was less than the median efficiency; this discrepancy indicates that the average efficiency is skewed by small or negative removals.

\section{Estimated Contaminant- Load Removal in the Village Brook Subbasin}

Contaminant-load reductions by hypothetical structural controls were determined for the Village Brook Subbasin in Brookline. The Village Brook Subbasin was selected as a "template" for potential load reductions across the lower Charles River Watershed for the following reasons:

- Potential construction and implementation of structural controls in the Village Brook Subbasin were more thoroughly evaluated by the CWP than controls in other subbasins in the lower Charles River Watershed (Center for Watershed Protection, 1999);

- Land use in the Village Brook Subbasin is generally representative of land use in the lower Charles River Watershed (fig. 3A);

- Road types and densities in the Village Brook Subbasin are generally representative of the roads in the lower Charles River Watershed (fig. 3B);

- The Village Brook Subbasin is relatively large, composing about 10 percent of the lower Charles River Watershed area;
- The types of BMP designs and the drainage areas to the controls selected for the Village Brook Subbasin are typical of structural BMPs identified by the CWP.

The CWP identified 19 potential structural controls in the Village Brook Subbasin that are mostly of the infiltration-filtration and biofiltration-bioretention types. Control types identified by CWP included bioretention structures, sand filters, dry swales, ponds, and forebays (table 2). Loads removed from existing ponds were not considered in this study, because the load reductions by these features were already incorporated into the lower Charles River loading estimates by Breault and others (2002); inclusion of these features would erroneously double their calculated effects on potential load reductions to the river. Drainage areas to the proposed structural controls range from less than an acre to 145 acres, but generally are only a few acres or less (median of 3.4 acres). Collectively, the contributing drainage area to the controls (471 acres) is about 21 percent of the Village Brook Subbasin. When the contributing drainage areas were normalized to $1.0 \mathrm{in}$. of treated runoff (drainage area multiplied by the inches of runoff treated by the control), the effective contributing drainage area to the controls was less than 10 percent of the Village Brook drainage area, because most of the controls treat only the first 0.5 in. of runoff. For example, the drainage area to VB-5 (65.0 acres) was multiplied by the inches of runoff reportedly treated by the control ( $0.5 \mathrm{in}$.) to yield the effective treated area for 1.0 in of rainfall (32.5 acre-inch).

The potential contaminant load reduction by the proposed structural controls in the Village Brook Subbasin first required estimates of inflow loads to each control. Inflow loads $\left(\operatorname{Lin}_{(i, j)}\right.$ in equation 1$)$ to each control were estimated from the yields (mass per unit area per unit time) reported by Breault and others (2002) from the single-family land-use subbasin multiplied by the drainage area to each control. The single-family land-use subbasin yields were chosen because the Village Brook Subbasin is predominantly single family (54 percent) and because the singlefamily land-use subbasin yields were believed to be the least affected by non-stormwater contamination. 
A. LAND USE

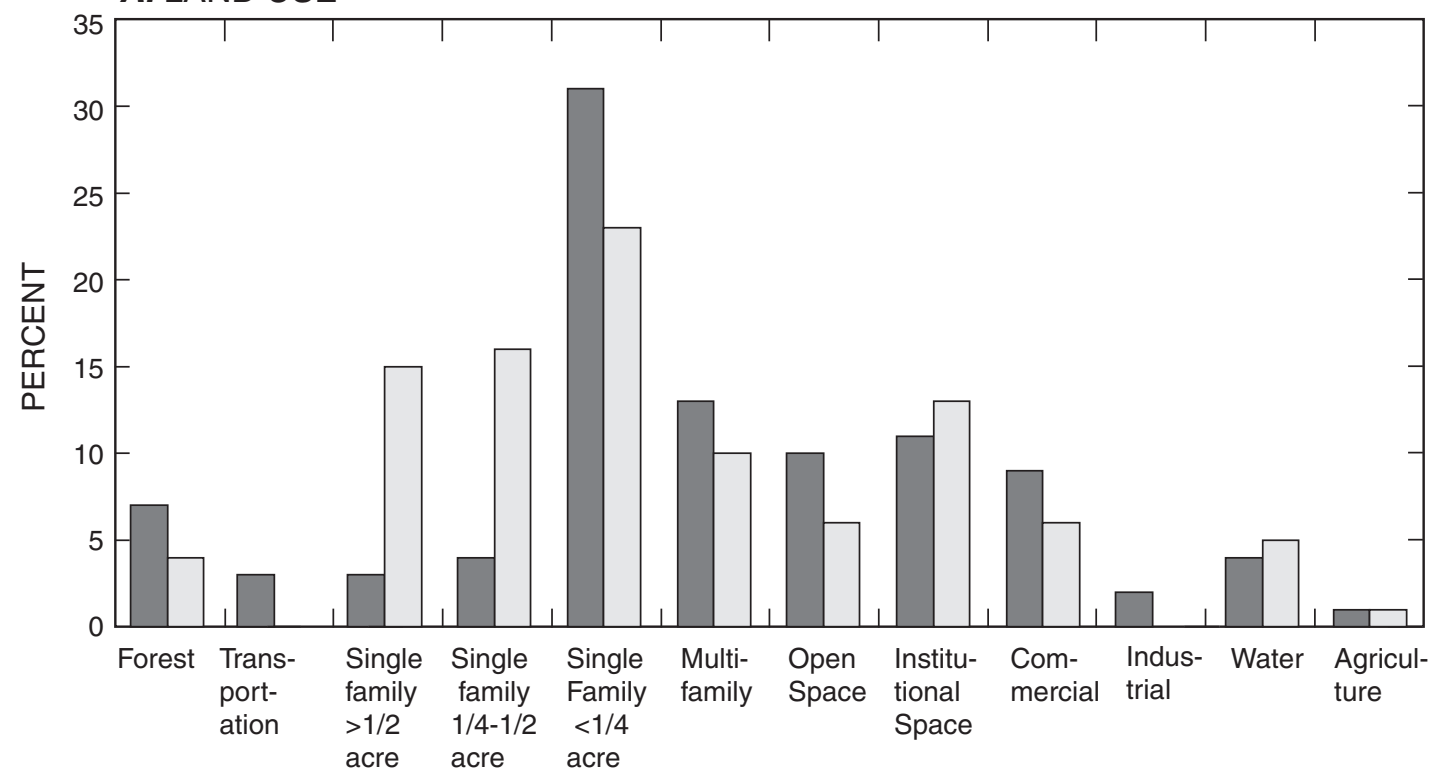

LAND-USE CATEGORY

B. ROAD TYPES

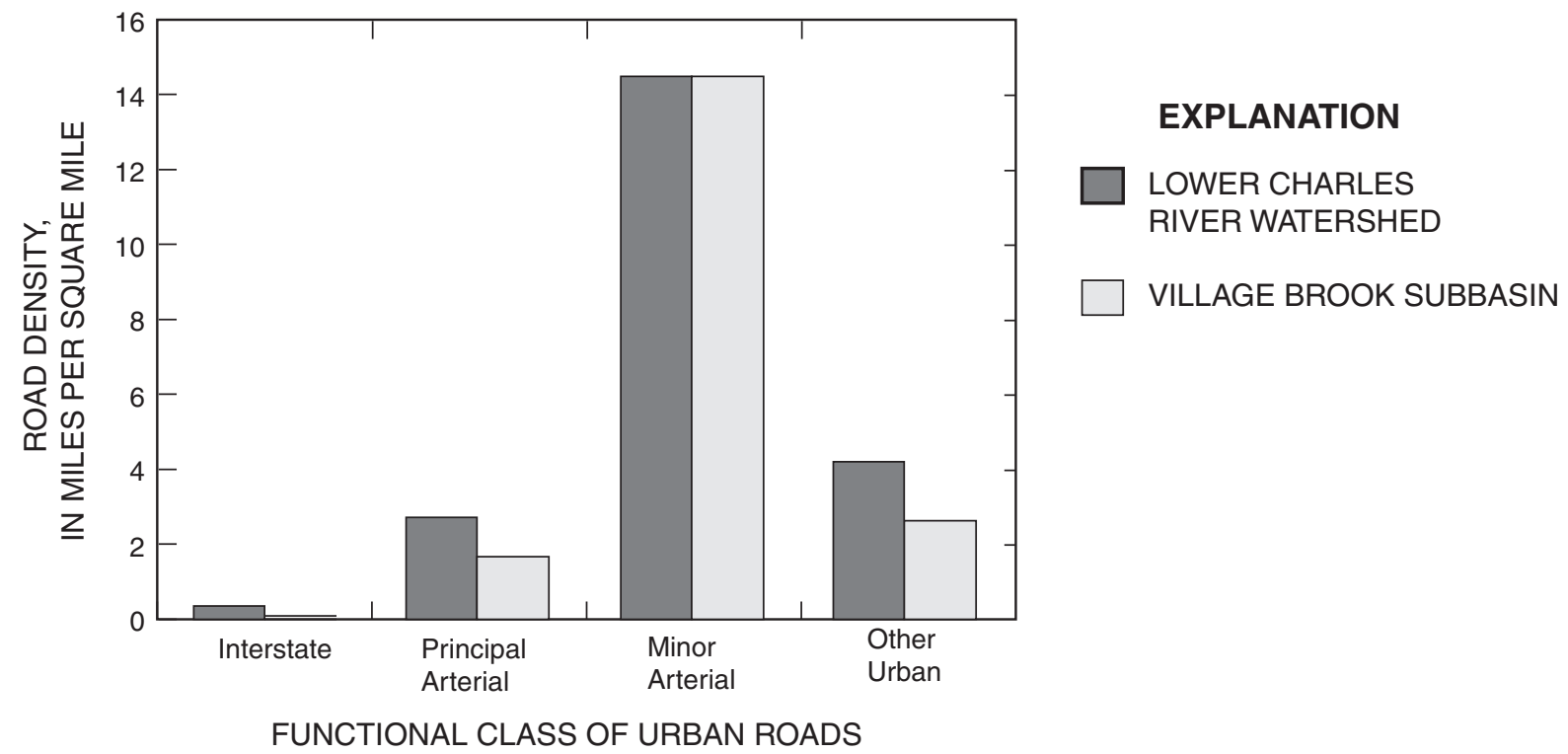

Figure 3. Comparison of $(A)$ land use and $(B)$ road types in the lower Charles River Watershed and Village Brook Subbasin. 
Table 2. Inventory of structural controls identified by the Center for Watershed Protection for the Village Brook Subbasin, lower Charles River Watershed, Massachusetts

[Modified from Brown and Schueler, 1997. CWP, Center for Watershed Protection; --, means not applicable because the load removal by these existing ponds was already incorporated into the lower Charles River loading estimates]

\begin{tabular}{|c|c|c|c|c|}
\hline $\begin{array}{c}\text { CWP } \\
\text { No. }\end{array}$ & Category & $\begin{array}{c}\text { Contributing } \\
\text { drainage area } \\
\text { (acres) }\end{array}$ & $\begin{array}{c}\text { Runoff } \\
\text { treated } \\
\text { (inches) }\end{array}$ & Site location \\
\hline & Biofiltration-Bioretention & 1.47 & 1.0 & Boston College Alumni Field Parking \\
\hline VB-2 & Biofiltration-Bioretention & 28.0 & 1.0 & Cleveland Circle \\
\hline VB-3 & Infiltration-Filtration & 3.01 & .5 & Chestnut Hill near Cleveland Circle \\
\hline VB-4 & Infiltration-Filtration & 60.0 & .5 & Waldstein Playground \\
\hline \multirow[t]{2}{*}{ VB-5 } & Detention-Retention & 65.0 & .5 & Reservoir Road and Crafts Road \\
\hline & $\begin{array}{l}\text { Infiltration-Filtration, } \\
\text { Biofiltration-Bioretention }\end{array}$ & 3.81 & .5 & Boylston Street near Reservoir Road \\
\hline VB-7 & Biofiltration-Bioretention & 1.94 & 1.0 & Fairway Road near Reservoir Road \\
\hline VB-8 & Biofiltration-Bioretention & 4.03 & 1.0 & Runkle Elementary School \\
\hline VB-9 & Biofiltration-Bioretention & 3.01 & .5 & Newbury College \\
\hline \multirow[t]{2}{*}{ VB-10 } & Biofiltration-Bioretention & 1.47 & .75 & Newbury College \\
\hline & Infiltration-Filtration & 1.02 & 1.0 & Lincoln Primary School \\
\hline VB-12 & Infiltration-Filtration & 50.0 & .5 & Cypress Playground \\
\hline VB-13 & Infiltration-Filtration & 100 & .33 & Robinson Playground \\
\hline VB-14 & Biofiltration-Bioretention & .32 & 1.0 & Brookline Public Housing near Chestnut Street and Pond Avenue \\
\hline \multirow[t]{2}{*}{ VB-15 } & Infiltration-Filtration & 145 & .25 & Adjacent to Willow Pond \\
\hline & Detention-Retention & -- & -- & Willow Pond \\
\hline VB-17 & Detention-Retention & -- & -- & Leverett Pond \\
\hline VB-18 & Biofiltration-Bioretention & 3.01 & 1.0 & Park near North End of Leverett Pond \\
\hline VB-19 & Detention-Retention & -- & -- & Village Brook Outfall to Leverett Pond \\
\hline
\end{tabular}

The removal efficiency $\left(E f f_{(i, j)}\right.$ in equation 1$)$ for each constituent $(i)$ was multiplied by $\operatorname{Lin}_{(i, j)}$ to determine the mass retained by each control $(j)$. The mass retained by each control was calculated for the median, upper quartile, lower quartile, and average removal efficiencies (table 3 ) to provide a range of load reductions that can be expected on the basis of performance data reported in the literature. The load exiting from each control $\left(\operatorname{Lout}_{(i, j)}\right)$ was calculated by:

$$
\operatorname{Lout}_{(i, j)}=\operatorname{Lin}_{(i, j)}-\left(\operatorname{Lin}_{(i, j)} \times E f f_{(i, j)}\right),
$$

where

$$
\begin{aligned}
& \operatorname{Lin}_{(i, j)} \text { is the load of constituent } i \text { entering control } j \text {, in } \\
& \text { mass per unit time; } \\
& \operatorname{Eff}_{(i, j)} \text { is the removal efficiency (percent) of } \\
& \text { constituent } i \text { for control } j \text {; and, }
\end{aligned}
$$

$\operatorname{Lout}_{(i, j)}$ is the load of constituent $i$ exiting control $j$, in mass per unit time.

The potential percentage of contaminant load that could be removed in the Village Brook Subbasin by structural controls was:

where

$$
P L R_{i}=\left(\frac{\sum_{j=1}^{n}\left(\operatorname{Lin}_{(i, j)}-\operatorname{Lout}_{(i, j)}\right)}{L_{i}}\right),
$$

$P L R_{\mathrm{i}}$ is the percent load reduction of constituent $i$;

$\operatorname{Lin}_{(i, j)}$ is the load of constituent $i$ entering control $j$, in mass per unit time;

$\operatorname{Lout}_{(i, j)}$ is the load of constituent $i$ exiting control $j$, in mass per unit time;

$n$ is the number of controls in the subbasin; and

$L_{i}$ is the total uncontrolled subbasin load for constituent $i$, in mass per time. 
Table 3. Estimated removal efficiencies in stormwater loads and total loads by hypothetical structural controls in the Village Brook Subbasin, lower Charles River Watershed, Massachusetts

\begin{tabular}{lcccc}
\hline \multirow{2}{*}{ Measure } & \multicolumn{4}{c}{ Percent removal } \\
\cline { 2 - 5 } & $\begin{array}{c}\text { Suspended } \\
\text { solids }\end{array}$ & $\begin{array}{c}\text { Fecal } \\
\text { coliform }\end{array}$ & $\begin{array}{c}\text { Total } \\
\text { phos- } \\
\text { phorus }\end{array}$ & $\begin{array}{c}\text { Total } \\
\text { lead }\end{array}$ \\
\hline & Stormwater load & & \\
Median & 15 & 7.8 & 7.5 & 9.3 \\
Upper quartile & 18 & 13 & 12 & 15 \\
Average & 19 & 16 & 17 & 18 \\
& 15 & 6.4 & 11 & 13 \\
& \multicolumn{2}{c}{ Total load } & & \\
Median & 14 & 7.5 & 6.2 & 8.9 \\
Upper quartile & 17 & 13 & 10 & 15 \\
Average & 18 & 16 & 14 & 17 \\
\hline
\end{tabular}

The stormwater load $P L R_{i}$ for the Village Brook Subbasin determined from the average removal efficiency (fig. 2) was 15 percent for suspended solids, 6.4 percent for fecal coliform bacteria, 11 percent for total phosphorus, and 13 percent for total lead (table 3). The $P L R_{i}$ decreased slightly for the annual loads because the dry-weather load (for example, contaminants conveyed by base flow from sources such as illicit connections, wash waters, and contaminated ground water) would not be affected by structural stormwater controls. The annual load decrease was the most pronounced for total phosphorus because a larger percentage of its total annual load was associated with dry weather.

\section{STREET SWEEPING}

Street sweeping as a water-quality management practice has received renewed attention by stormwater managers in recent years. This renewed interest stems from reported improvements in sweeper technology and the recognition that opportunities for implementing structural controls are limited in highly urbanized areas. Street sweeping affects only areas that are sweepable; hence, understanding the potential effectiveness of this management practice as a water-quality control requires knowledge of the relative importance of and the buildup process for contaminants originating from streets. The characteristics of street contaminants, reviewed from the literature, provided a framework for modifying the StormWater Management Model (SWMM) (Huber and Dickinson, 1992). The SWMM application developed by the USGS to simulate runoff in the single-family land-use basin of the lower Charles River Watershed (Zarriello and Barlow, 2002) was modified to simulate contaminant buildup and washoff, and the effects of street sweeping, on selected constituents in this basin.

\section{Contaminants on Streets}

Reported loading from street surfaces varies widely among source area studies and from storm to storm within the same study. Pitt and Bozeman (1980), Bannerman and others (1993), Pitt and others (1995), Steuer and others (1997), and Smith (2002) attribute this variability to many factors, including differences in basin characteristics, study methods, and the inherent variability in the source loading factors. Consequently, it would be unreasonable to assume that constituent buildup and loadings from streets can be represented with great certainty. Nonetheless, the literature was reviewed to establish the relative importance of streets as sources of water-quality contaminants and to guide the SWMM water-quality buildup and washoff calibration. Emphasis was given to recent publications because these studies represent advances in sampling and analytical methods compared to the main body of literature, which was completed in the late 1970s and early 1980s under the National Urban Runoff Program (NURP).

In summarizing the studies, Sartor and Gaboury (1984) report that on average, one kilogram of street dirt contains 3 million colony forming units (CFU) of fecal coliform bacteria. Burnhart (undated) examined sources of bacteria in stormwater at commercial, industrial, and residential-institutional land-use sites in Wisconsin. Runoff samples were collected from streets, parking lots, roofs, lawns, sidewalks, and driveways. These samples indicated that nearly 92 percent of the bacteria originated from streets in the residential-institutional land-use site, whereas only about 33 and 19 percent of the bacteria originated from streets in the industrial and commercial land-use sites, respectively. Burnhart suggests that bacteria incubate in puddles on street surfaces between storms. He also concluded that dog feces accounted for only about 12 percent of the total bacteria at the storm-sewer outfall. 
Steuer and others (1997) examined source loads from a predominantly residential basin in Marquette, Michigan. Their findings indicate that, for a given constituent, areas producing the highest concentrations can change from storm to storm, which they suggest is caused by varying buildup mechanisms. The dominant source of suspended solids was from streets with low traffic volume ( 27 percent) and the dominant source of total phosphorus (26 percent) was from lawns. For each type of source area, Steuer and others (1997) compared the ratio of constituent load from each source area to the total basin load, to the ratio of the runoff volume from that type of source area to the total basin runoff volume. This comparison indicated that suspended solids were proportional to runoff volume from low traffic streets, but lawns contributed a total phosphorus load that was 4.5 times their contributing runoff volume.

Waschbusch and others (1999) collected runoff samples from two predominantly residential land-use subbasins. Sample analysis indicated that streets were the source of most suspended solids ( 73 and 81 percent of the total load for the two study sites), which is about twice the percentage of the runoff volume from streets (37 and 38 percent of the total basin runoff). Total phosphorus loads were proportional to the percentage of runoff at one site ( 37 percent of the total) and about half of the percentage of runoff at the other site (14 percent).

Bannerman and others (1993) reported that 78 percent of the fecal coliform bacteria load for one of the same residential land-use study subbasins studied by Waschbusch and others (1999) originated from streets. Bannerman and others (1993) report that for most constituents, 75 percent or more of the total residential basin loads originate from street surfaces; total phosphorus was one of the exceptions, which originated mostly from driveways and lawns. This study also concluded that streets and parking lots are a critical source area for many contaminants in the commercial and industrial land-use areas. It was further concluded that best management practices that target streets and parking lots would provide the most costeffective way for controlling contaminant loads.

Baldys and others (1998) investigated urban stormwater quality from 26 basins in Dallas-Fort Worth, Texas, and found that residential land-use basins produced higher concentrations of bacteria and nutrients than commercial and industrial land-use basins. Industrial land-use basins, however, produced higher concentrations of suspended solids and trace metals than did the residential and commercial land-use basins.

Pitt (1985) characterized buildup of street dirt from two residential areas in Bellevue, Washington, and summarized findings by others. Initial loadings of solids (load on streets after the first few days following a cleansing storm) ranged from 59 to $1,130 \mathrm{~kg} /$ curb-mi; the initial median load was $320 \mathrm{~kg} /$ curb-mi and the mean was about $370 \mathrm{~kg} /$ curb-mi. Accumulation rate of solids on streets several days after a cleansing storm ranged from 2.6 to $119 \mathrm{~kg} / \mathrm{curb}-\mathrm{mi} / \mathrm{d}$; median and mean accumulation rates were 2.2 to $33 \mathrm{~kg} / \mathrm{curb}-\mathrm{mi} / \mathrm{d}$, respectively. Initial loading of solids on rough streets was an average of seven times greater than the initial loading on smooth streets and as much as 14 times greater than the accumulation rate on smooth streets several days after a storm. Bender and Terstriep (1984) reported an average solids buildup rate of $1.2 \mathrm{~kg} /$ curb-mi/d on a residential basin in Champaign, Illinois.

Pitt and others (1995) examined the toxicity of runoff from urban areas and found that most runoff originating from streets (67 percent of the samples taken) was moderately toxic. Buckler and Granato (1999) reviewed existing highway-runoff studies and determined that road runoff was not always acutely toxic, but was associated with adverse ecological effects, including increased contaminant concentrations in aquatic organisms and receiving waters, and decreased aquatic-organism diversity. Findings from these studies underscore the importance of streets as a source of contaminants to receiving waters and the need to control contaminated runoff from street surfaces.

Fine-grained particles provide the main bonding sites for contaminant adsorption. The amount of phosphorus adsorbed to clay-size minerals depends on the phosphorus concentrations and the number of available ion-exchange sites (White, 1981). Sartor and others (1972) found that particles less that $104 \mu \mathrm{m}$ had adsorbed 86 percent of the street phosphates, but made up only 16 percent of the suspended solids by dry weight. Sartor and Gaboury (1984) summarized pollutant concentrations as a function of particle size from the NURP studies; these studies indicated that 
fine-grained size fractions (smaller than $250 \mu \mathrm{m}$ ) adsorbed 62 percent of the total lead but made up only 42 percent of the mass by dry weight. Sartor and Boyd (1975) reported that 56 percent of the phosphates were associated with particles smaller than $43 \mu \mathrm{m}$, but made up only 6 percent of the suspended solids by dry weight in street runoff from a low-density road area. The studies by Sartor and Boyd (1972) and Sansalone and others (1995) found that heavy metals were more equally distributed among size fractions, but still tended to have more of their mass associated with finegrained particles. Sartor and Boyd (1972) reported that 50 percent of metals were sorbed to particles smaller than $43 \mu \mathrm{m}$. Street sweeping was found to have little effect on water quality by the Washington State Dept. of Transportation (1995), because the sweepers did not effectively remove fine particles. Thus, it can be expected that sweepers that are ineffective in removing fine-grained particles will be less effective in removing constituents associated with those particles.

\section{Street Sweeping as a Water-Quality-Management Practice}

Efficiencies of street sweepers in removing dirt and associated contaminants differ widely. Few studies report the sweeper efficiencies for removing phosphorus and metals, and information about the removal of bacteria by street sweeping is virtually nonexistent. Most street sweeper studies have examined the effects of sweeping by analysis of end-of-pipe runoff from relatively large drainage areas. Hence, the efficiencies reported could reflect factors other than sweeper performance.

\section{Sweeper Types and Efficiencies}

Three types of street sweepers are commonly in use: mechanical, vacuum-assisted, and regenerative air. Performance of vacuum and regenerative-air sweepers is poorly documented in the peer-reviewed literature. Most literature on these types of sweepers is published in trade journals or other non-scientific publications.

Mechanical sweepers lift dirt off the street by a rotating broom and feed it to a hopper by a conveyor system. A water spray is often used to control dust. This is the most common type of sweeper, but typically removes only coarse particles (larger than $400 \mu \mathrm{m}$ ) and is ineffective at removing fine particles (Horner and others, 1994). Most National Urban Runoff Program (NURP) studies conducted in the late 1970s and early 1980s examined the effectiveness of mechanical sweepers; those studies concluded that street sweeping was not a viable water-quality management practice (Smith and Lord, 1990; Sartor and Gaboury, 1984; Athayde and others, 1983; Sartor and Boyd, 1975). Under favorable conditions, Sartor and Gaboury (1984) state that end-of-pipe loads of solids can be decreased by 30 percent by street sweeping. One key criterion for favorable performance is a distinct wet and dry season, a climatic condition that is not typical of the Boston area.

Bender and Terstriep (1984) examined the effectiveness of brush-style sweepers in a residential and commercial land-use basin in Champaign, Illinois; the effectiveness of solids removal by sweeping averaged 42 percent (with a range of 14 to 55 percent for one sweeping per week and 23 to 62 percent for two sweepings per week). They found that particles smaller than $250 \mu \mathrm{m}$ were poorly captured by sweeping, as evidenced by the mean size of particulates remaining on the street after sweeping. Their findings also indicate that log-normal distributions of event mean concentrations (EMCs) before and after street sweeping were not significantly different for the residential basin at the 90-percent confidence interval for most constituents, including the constituents examined in this study.

Shoemaker and others (2000) reported that mechanical sweepers removed 55 percent of suspended solids, but the efficiency of mechanical sweepers in capturing particles smaller than $10 \mu \mathrm{m}$ ranged from -6.7 to 8.6 percent. A negative efficiency indicates that more material was added than removed, possibly because the abrasive action of the mechanical sweeper broke large particles into small ones.

Pitt (1985) concluded that sweeper performance was a function of the initial constituent load; the effectiveness of street sweeping was poor to negligible until a minimal initial load existed at which point the effectiveness would slowly approach 30 percent for suspended solids. Pitt also concluded that intensive street sweeping may remove only a tenth of the constituent load associated with particulate matter.

The Northern Virginia Planning District Commission (1992) reported that a mechanical street sweeper making one pass per week in a mediumdensity residential area removed 9 to 11 percent of 
the total phosphorus load and 13 to 15 percent of the total lead load. Shoemaker and others (2000) report mechanical sweep efficiencies of 40 percent for total phosphorus and 35 percent for total lead.

Vacuum-assisted sweepers combine a mechanical sweeper (such as a rotating broom) with a highpower vacuum. Some vacuum-assisted sweepers use a water spray to control dust and others operate completely dry with a continuous filtration system. Shoemaker and others (2000) report removal efficiencies of 93 percent for suspended solids, 74 percent for total phosphorus, and 76 percent for total lead for dry vacuum-assisted sweeper. Shoemaker and others (2000) also report that two different models of wet vacuum-assisted sweepers removed 40 and 82 percent of particles finer than $10 \mu \mathrm{m}$ and a dry vacuumassisted sweeper removed nearly 100 percent of particles finer than $10 \mu \mathrm{m}$.

The Northern Virginia Planning District Commission (1992) reported that one pass per week with a vacuum-assisted sweeper in a medium-density residential area removed 14 to 18 percent of the total phosphorus load and 28 to 33 percent of the total lead load. The type of vacuum-assisted sweeper was not identified in this report, but nevertheless, the removal rates reported were about twice those reported for mechanical sweepers. The Northern Virginia Planning District Commission, in conjunction with the Lake Barcroft Watershed Improvement District (Finely, 2000), found that a dry-vacuum-assisted sweeper removed 141 percent more material than a modern mechanical sweeper it swept directly behind and 44 percent more material than a regenerative air sweeper it swept directly behind.

The Terrene Institute (1998) reported that dryvacuum-assisted sweepers reduced solid loads by 35 to 80 percent and nutrients loads by 15 to 40 percent. Bannerman (1999) stated that dry vacuum-assisted sweepers removed as much as 98 percent of the street dirt, including the fine-grained size fraction. The removal rate reported for nutrients by the Terrene Institute appears to be inconsistent with the solids removal rate reported by Bannerman; comparable removal rates would be expected for nutrients if finegrained particles were effectively removed. Sutherland and Jelen (1997) reported simulated removal rates for solids by dry vacuum-assisted sweepers of 87 percent when swept twice per week to 51 percent when swept once a month.
Regenerative-air sweepers combine a mechanical sweeper to loosen dirt with forced air to dislodge the remaining dirt. A high-power vacuum with a continuous filtration system captures the dirt and recycles the air. Shoemaker and others (2000) reported a regenerative-air sweeper removed 31 percent of particles smaller than $10 \mu \mathrm{m}$. Sutherland and Jelen (1996) reported simulated removal rates for solids by regenerative-air sweepers of 71 percent when swept twice per week to 43 percent when swept once a month.

\section{Factors that Affect Sweeper Performance}

Accumulation of dirt and associated pollutants depends in large part on whether the street is curbed (Smith and Lord, 1990). The Northern Virginia Planning District Commission (1992) found that 90 percent of the roadside dirt accumulates within the first foot of the curb. The Federal Highway Administration (Young and others, 1996) suggested that eliminating curbs allows scattering of particulates onto vegetative areas and can reduce buildup of street dirt and pollutants. The simulated buildup rates described later in this report are typical of curbed streets, which are characteristic of most streets in the study area. Buildup rates in this analysis may overestimate buildup of dirt on non-curbed streets.

One of the major impediments to removing debris from streets is vehicular parking or other obstructions that prevent effective sweeping (Camp, Dresser, and McKee, 1993; Washington State Department of Ecology, 1999; Northern Virginia Planning District Commission, 1992; Washington State Department of Transportation, 1995). Thus, street parking would need to be regulated to allow effective sweeping.

Street condition and material also can affect the performance of street sweepers (Pitt, 1985; Shoemaker and others, 2000). Streets in poor condition (cracked and broken pavement) decrease the effectiveness of street sweeping because particles lodge in the irregularities of the street surface, but these particles could wash off during storms. Street condition likely affects mechanical sweepers more than vacuum or regenerative air sweepers; however, no information was found concerning sweeper performance under different street conditions. The effectiveness of mechanical and vacuum sweepers decreases if the street surface is wet (Shoemaker and others, 2000). 
The effectiveness of street sweeping can increase if multiple passes are made; the Washington State Department of Ecology (1999) found that 50 percent of the solids were removed by one pass and 75 percent with two passes of a mechanical sweeper. Operation speed also affects the effectiveness of street sweepers. Sweepers are typically designed to operate at a maximum efficiency of 6 to $8 \mathrm{mi} / \mathrm{hr}$ (Shoemaker and others, 2000); sweepers operated at higher speeds have decreased effectiveness.

\section{Model Simulation}

The rainfall-runoff model, SWMM, previously developed by Zarriello and Barlow (2002) to simulate runoff in the single-family residential land-use subbasin, was modified to include simulation of constituent buildup, washoff, and the effects of street sweeping on suspended solids, fecal coliform bacteria, total phosphorus, and total lead in stormwater runoff. This subbasin was selected to simulate the effects of street sweeping because it was previously calibrated to simulate storm runoff (Zarriello and Barlow, 2002) and because constituent loads were measured during multiple storms (Breault and others, 2002). This subbasin also represents the predominant land-use type in the lower Charles River Watershed.

The single-family residential land-use subbasin model was modified from one subcatchment into two to allow simulation of two land-use types-street and non-street. Separate simulation of street and non-street types allows sweeping to be applied only to the street subcatchment. While the model availability factor (AVSWP) could have been used to scale street sweeping to the area that is sweepable in the single subcatchment model, the AVSWP variable represents a direct fraction of the sweepable area in the two-subcatchment model. Therefore, the value of AVSWP can be easily modified to test alternative availability factors without having to scale the value by the proportion of street and non-street areas. The separate land-use model also facilitates extrapolation of street-sweeping effects to other areas based on road density.

The street subcatchment area (39.6 acres) was set equal to the effective impervious area of the single subcatchment model (17.4 percent of 227.7 acres) previously obtained from model calibration and examination of rainfall-runoff coefficients for small summer storms (Zarriello and Barlow, 2002) because the street subcatchment area is about equal to the total subbasin road length $(9.8 \mathrm{mi})$ times a width of $33 \mathrm{ft}$. It was assumed that streets primarily represent the effective impervious area (areas that drain directly to the storm-sewer system) in the subbasin and that other impervious surfaces such as driveways and rooftops are primarily non-effective (because they drain onto pervious areas). Simulated runoff by the two-subcatchment model is the same as the runoff simulated by the single-subcatchment model.

The two-subcatchment model also enabled constituent buildup to be treated differently for each landuse type. Constituent buildup was simulated on streets as a load per unit curb length by the Michaelis-Menton method (Huber and Dickinson, 1992). This method computes constituent buildup as a rapid initial rate that asymptotically approaches a defined limit by:

$$
Q=\frac{Q F A C T(1) \times t}{Q F A C T(3)+t},
$$

where

$Q$ is the built-up load (mass),

QFACT(1) is the buildup limit (mass per $100 \mathrm{ft}$ of road curb),

QFACT(3) is time for the buildup load to reach half the buildup limit (day) and

$t$ is the elapsed time (day).

In a summary of several studies across the United States, Sartor and Boyd (1972) indicated that solids buildup on residential streets follows a pattern best described by the Michaelis-Menton method. Ball and others (1996), however, concluded that the buildup of solids and metals on a suburban street in Sydney, Australia, approximates a power function, but attributed this difference to climate differences and changes in source loadings rates since the early 1970s. These findings underscore that constituent buildup processes are poorly understood. Variable values used to simulate buildup are generally obtained from model calibration and are not measured directly. 
Non-street constituent buildup was simulated as a load per unit area by a power equation. Constituent buildup is less rapid than with the Michaelis-Menton equation initially, but both methods limit constituent buildup by a user-defined value.

Washoff from impervious and pervious surfaces is simulated by the same method in SWMM. The washoff of constituent load built up over the catchment is estimated by the following equation:

$$
P O F F=(R C O E F / 3600) \times r^{W A S H P O} \times P S H E D,(4)
$$

where:

POFF is the load washed off at each time step (mass per sec),

$R C O E F$ is a washoff coefficient (in $\left./ \mathrm{hr}^{-W A S H P O} / \mathrm{s}\right)$,

$r$ is the runoff rate $(\mathrm{in} / \mathrm{hr})$,

$W A S H P O$ is an exponent of the runoff rate (unitless), and

PSHED is the quantity of the constituent built up at each time step (mass).

The constituent washoff load $(P O F F)$ is subtracted from the quantity of the constituent built up over the catchment (load available for washoff) at each time step to calculate the new load remaining on the subcatchment. Examination of the washoff equation indicates that increasing the value of WASHPO results in lower values of $P O F F$ because runoff $(r)$, in inches per hour, is typically less than one. Land-use types were assigned different WASHPO and RCOEF values for each constituent. Neither buildup or washoff variable values are allowed to change seasonally in SWMM.

The dry-weather load was considered unavailable to street sweeping because this load is transported by ground water and is not considered part of the builtup load that is sweepable. To simulate dry-weather loads described by Breault and others (2002), a constant constituent concentration was specified for ground water to preclude this portion of the subbasin load from being swept. Loads that result from erosion or precipitation contributions, and load removals by catch basins (structures that trap solids) were not included in the simulations. Erosion was considered negligible because this subbasin is an older, undisturbed residential area that channels runoff in streets and storm drains that are not prone to erosion. Erosion could be a factor in disturbed areas and in areas that are not storm sewered, which would diminish the relative benefits of street sweeping. The quality of precipitation could affect the source loadings for total phosphorus simulations (Colman and others, 2001), but is likely not a factor for the other constituents simulated. Huber and Dickinson (1992) state that catch basins usually have a negligible effect on simulation results, and efforts to simulate these features are seldom justified. In addition, the estimated constituent loads by Breault and others (2002) reflect the effects of existing catch basins in the watershed, which in turn have been incorporated into the variable values for the calibrated model.

\section{Calibration}

Model-simulated constituent loads for the singlefamily land-use subbasin were calibrated to loads reported by Breault and others (2002) for the 2000 water year. Annual dry-weather, wet-weather, and total loads were calibrated to the average-mean and weighted-mean loads reported (table 4). Although the simulated and reported annual loads match closely, the model representation of source areas, buildup processes and washoff rates could be non-unique. Therefore, this calibration does not ensure an accurate, predictive water-quality model. Other combinations of process-variable values could produce similar results.

Table 4. Reported and simulated constituent loads for the single-family land-use subbasin, 2000 water year, lower Charles River Watershed, Massachusetts

[Reported values are the average of the average-mean and weighted-mean loads reported by Breault and others, 2002. TCFU, trillion colony forming units]

\begin{tabular}{ccccc}
\hline $\begin{array}{c}\text { Annual 2000 } \\
\text { water year }\end{array}$ & $\begin{array}{c}\text { Suspended } \\
\text { solids } \\
\text { (kilograms) }\end{array}$ & $\begin{array}{c}\text { Fecal } \\
\text { coliform } \\
\text { (TCFU) }\end{array}$ & $\begin{array}{c}\text { Total } \\
\text { phosphorus } \\
\text { (kilograms) }\end{array}$ & $\begin{array}{c}\text { Total } \\
\text { lead } \\
\text { (grams) }\end{array}$ \\
\hline
\end{tabular}

Dry

$\begin{array}{lllll}\text { Reported } & 522 & 9.24 & 23.8 & 313\end{array}$

$\begin{array}{lllll}\text { Simulated } & 522 & 9.25 & 23.8 & 317\end{array}$

Wet

\begin{tabular}{lllll} 
Reported & 13,200 & 48.3 & 55.1 & 5,850 \\
Simulated & 13,200 & 53.4 & 55.1 & 5,840 \\
Total & & & & \\
Reported & 13,700 & 57.6 & 78.9 & 6,160 \\
Simulated & 13,700 & 57.5 & 78.9 & 6,160 \\
\hline
\end{tabular}


Alternative model variable values can also affect load reductions obtained by street sweeping as described later in the report.

After the model was calibrated to annual loads, the simulated loads for eight sampled storms were compared to the measured loads reported by Breault and others (2002). The sampled storms represent the best available individual storm-load data for evaluating and adjusting the water-quality simulations. The initial load for suspended solids was oversimulated for largest storm (June 6, 2000) and all but the smallest storms were undersimulated. The buildup and washoff variables were adjusted to better match individual storm loads while the annual load calibration was maintained. The final calibrated variable values (table 5) provided a close match between simulated and measured storm loads (fig. 4). The average error (AE) and the root mean square error (RMSE) of the percent difference between measured and simulated values were computed (table 6). These values provide a measure of the model accuracy within the range of storm conditions sampled and the accuracy of the estimated loads. AE and RMSE are calculated by

$$
\begin{gathered}
A E=\left(\frac{\sum r}{n}\right) \times 100, \\
R M S E=\left(\sqrt{\frac{\sum r^{2}}{n}}\right) \times 100,
\end{gathered}
$$

where

$$
r=\frac{\text { simulated value-observed value }}{\text { observed value }},
$$

and

$$
n=\text { number of storms } .
$$

The AE and RMSE were least for total lead and greatest for fecal coliform bacteria. The AE for suspended solids and total lead loads indicated that the model undersimulated these loads when the runoff was undersimulated and oversimulated loads when the runoff was oversimulated for about half the storms. Fecal coliform bacteria colonies were oversimulated when runoff was oversimulated and undersimulated when runoff was undersimulated for five of the eight sampled storms. Total phosphorus loads were generally undersimulated when the
Table 5. Calibrated Stormwater Management Model variable values for constituent buildup and washoff for the single-family land-use subbasin, lower Charles River Watershed, Massachusetts

\begin{tabular}{|c|c|c|c|c|c|}
\hline Land use & QFACT(1) & QFACT(2) & QFACT(3) & WASHPO & RCOEF \\
\hline \multicolumn{6}{|c|}{ Suspended solids } \\
\hline Street & 2. 6 & -- & 2.5 & 1.85 & 10.7 \\
\hline Non-street & 10.2 & 8.6 & 12.1 & .30 & 15.4 \\
\hline \multicolumn{6}{|c|}{ Fecal coliform bacteria } \\
\hline Street & .005 & -- & 3.5 & 2.87 & 9.1 \\
\hline Non-street & .82 & 2.5 & 6.0 & .86 & 15.0 \\
\hline \multicolumn{6}{|c|}{ Total phosphorus } \\
\hline Street & .008 & -- & 2.1 & 1.44 & 9.77 \\
\hline Non-street & .860 & 1.0 & 8.0 & .76 & 14.5 \\
\hline \multicolumn{6}{|c|}{ Total lead } \\
\hline Street & .002 & -- & 2.2 & 1.56 & 2.70 \\
\hline Non-street & .005 & 1.0 & 6.0 & .61 & 12.7 \\
\hline
\end{tabular}

[Street buildup is represented by the Michaelis-Menton equation, which does not use variable QFACT(2); non-street buildup is represented by a linear equation. --, no value]

runoff was oversimulated and oversimulated when runoff was undersimulated. This indicates that for suspended solids, total lead, and fecal coliform bacteria, the model error in simulating these constituents can be at least partly attributed to error in simulating the storm runoff volume, whereas the model error in simulating total phosphorus is attributed to error in the representation of the buildupwashoff process.

Of the eight sampled storms, simulated constituent loads from pervious areas were generated only during the June 6, 2000, storm. This was also the only storm simulated during the 2000 water year that generated appreciable pervious-area runoff. Total runoff from the June 6 storm accounted for about 10 percent of the total annual runoff; pervious-area runoff from this storm was less than 1 percent of the total annual runoff. The June 6 storm accounted for about 8 percent of the total annual load for suspended solids, 12 percent for fecal coliform bacteria, 8 percent for total phosphorus, and 5 percent for total lead. The pervious-area load from this storm (which represents most of the pervious area runoff during the water year) was a small percentage of the total annual load-about 5 percent for suspended solids, 9 percent for fecal coliform bacteria, 6 for total phosphorus, and 1 for total lead. 

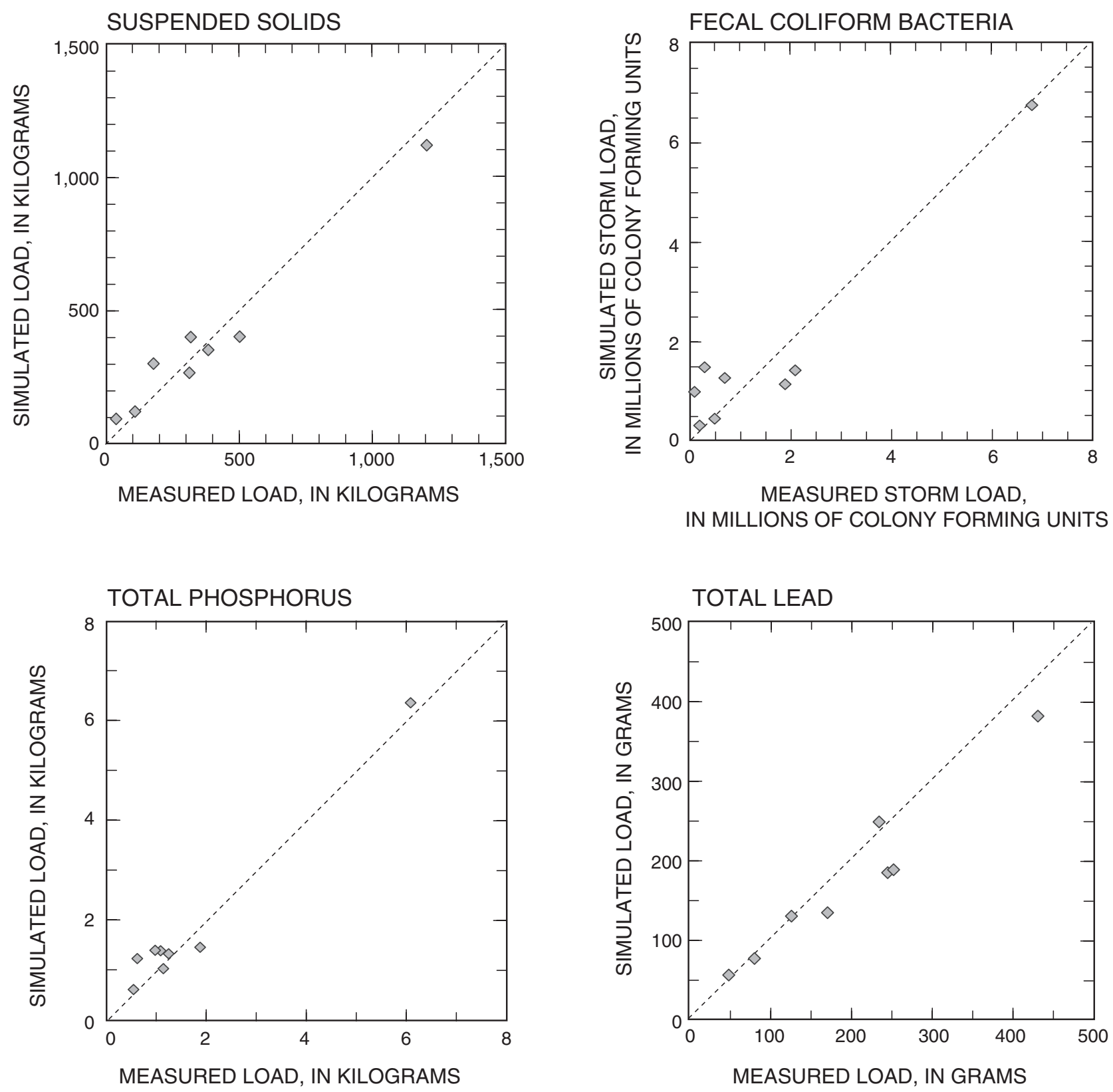

Figure 4. Relation of simulated constituent loads to measured loads for eight sampled storms between January 10 and July 27, 2000, at the single-family land-use subbasin, lower Charles River Watershed, Massachusetts.

Seemingly, appreciable percentages of contaminants should be available for collection by street sweeping in this subbasin since they were simulated as originating from streets. Street runoff accounted for 95 percent of the total annual surface-runoff load for suspended solids, 91 percent for fecal coliform bacteria, 94 percent for total phosphorus, and 99 percent for total lead. Dry-weather loads, which were unavailable for sweeping, accounted for 4 percent of the total annual load for suspended solids, 16 percent for fecal coliform bacteria, 30 percent for total phosphorus, and 5 percent for total lead. Therefore, the portion of the total constituent load available for sweeping ranged from about 92 percent for suspended solids, 76 percent for fecal coliform bacteria, 66 percent for total phosphorus, and 94 percent for total lead. 
Table 6. Measured and simulated storm runoff and constituent loads for sampled storms in the single-family land-use subbasin, lower Charles River Watershed, Massachusetts

[AE, average error; RMSE, root mean square error]

\begin{tabular}{|c|c|c|c|c|c|c|c|}
\hline $\begin{array}{c}\text { Storm } \\
\text { date }\end{array}$ & Measured & Simulated & $\begin{array}{c}\text { Percent } \\
\text { difference }\end{array}$ & $\begin{array}{c}\text { Storm } \\
\text { date }\end{array}$ & Measured & Simulated & $\begin{array}{c}\text { Percent } \\
\text { difference }\end{array}$ \\
\hline & \multicolumn{3}{|c|}{ Runoff, in cubic feet } & & \multicolumn{3}{|c|}{ Suspended solids load, in kilograms } \\
\hline $1-10-2000$ & 154,000 & 127,000 & -18 & $1-10-2000$ & 375 & 348 & -7.2 \\
\hline $4-09-2000$ & 102,000 & 98,800 & -3.1 & $4-09-2000$ & 307 & 262 & -15 \\
\hline $5-18-2000$ & 66,300 & 83,300 & 26 & $5-18-2000$ & 96 & 116 & 22 \\
\hline $6-02-2000$ & 69,200 & 85,500 & 24 & $6-02-2000$ & 497 & 398 & -20 \\
\hline $6-06-2000$ & 713,000 & 520,000 & -27 & $6-06-2000$ & 1,210 & 1,120 & -7.6 \\
\hline $7-09-2000$ & 75,900 & 61,800 & -19 & $7-09-2000$ & 170 & 297 & 74 \\
\hline $7-16-2000$ & 38,300 & 32,200 & -16 & $7-16-2000$ & 28.4 & 88.7 & 210 \\
\hline $7-26-2000$ & 244,000 & 237,000 & -2.9 & $7-26-2000$ & 311 & 396 & 27 \\
\hline \multirow{3}{*}{$\begin{array}{r}\text { AE } \\
\text { RMSE }\end{array}$} & ........ & ........... & -4.5 & \multirow{3}{*}{$\begin{array}{r}\mathrm{AE} \\
\mathrm{RMSE}\end{array}$} & ................ & ............ & 36 \\
\hline & & . & 19 & & & .................. & 81 \\
\hline & \multicolumn{3}{|c|}{ Fecal coliform, in TCFU } & & \multicolumn{3}{|c|}{ Total phosphorus load, in kilograms } \\
\hline $1-10-2000$ & 700 & 1,070 & 53 & $1-10-2000$ & 0.82 & 1.4 & 28 \\
\hline $4-09-2000$ & 100 & 265 & 160 & $4-09-2000$ & .54 & 1.23 & 99 \\
\hline $5-18-2000$ & 500 & 69.9 & -86 & $5-18-2000$ & .53 & 1.03 & -9.3 \\
\hline $6-02-2000$ & 300 & 1,770 & 490 & $6-02-2000$ & 1.70 & 1.46 & -22 \\
\hline $6-06-2000$ & 6,800 & 6,600 & -3 & $6-06-2000$ & 5.90 & 6.35 & 4.6 \\
\hline $7-09-2000$ & 1,900 & 510 & -73 & $7-09-2000$ & 1.10 & 1.33 & 6.7 \\
\hline $7-16-2000$ & 200 & 85.8 & -57 & $7-16-2000$ & .40 & .615 & 13 \\
\hline $7-26-2000$ & 2,100 & 1,580 & -25 & $7-26-2000$ & .84 & 1.400 & 43 \\
\hline $\mathrm{AE}$ & .................. & ............................ & 58 & \multirow{13}{*}{$\begin{array}{r}\mathrm{AE} \\
\mathrm{RMSE}\end{array}$} & …................ & . n................. & 20 \\
\hline \multirow[t]{2}{*}{ RMSE } & .................... & ............................. & 190 & & $\ldots \ldots \ldots$ & ...................... & 41 \\
\hline & \multicolumn{3}{|c|}{ Total lead load, in grams } & & & & \\
\hline $1-10-2000$ & 240 & 183 & -24 & & & & \\
\hline $4-09-2000$ & 160 & 127 & -21 & & & & \\
\hline $5-18-2000$ & 56 & 62.8 & 12 & & & & \\
\hline $6-02-2000$ & 250 & 188 & -25 & & & & \\
\hline $6-06-2000$ & 450 & 402 & -11 & & & & \\
\hline $7-09-2000$ & 110 & 122 & 11 & & & & \\
\hline $7-16-2000$ & 24 & 39.6 & 65 & & & & \\
\hline $7-26-2000$ & 230 & 254 & 10 & & & & \\
\hline $\mathrm{AE}$ & ㄱ. & …………. & 2.3 & & & & \\
\hline RMSE & .................... & ........................... & 28 & & & & \\
\hline
\end{tabular}




\section{Sweeping Efficiencies and Frequencies Evaluated}

Street-sweeping efficiencies evaluated for the purposes of this study (table 7) were assigned to be representative of mechanical sweepers (low-end efficiencies), wet assisted-vacuum sweepers and regenerative-air sweepers (mid-range efficiencies), and dry assisted-vacuum sweepers (high-end efficiencies). Removal efficiencies were also simulated for the "best available technology" sweepers, which were assigned from the highest removal efficiencies reported in the literature; however, these sweeper efficiencies are not well documented. For each class of sweeper simulated, removal efficiencies were highest for suspended solids, lowest for fecal coliform bacteria and total phosphorus, and intermediate for the removal of lead. Lead was assigned a higher sweeper efficiency than phosphorus and fecal coliform bacteria because the literature indicates that (1) its bonding sites are not as strongly associated with fine particles as phosphorus, and (2) lead originates from streets to a greater extent than phosphorus and bacteria.

All simulations assumed an availability factor (SWMM variable AVSWP) of 80 percent (not reflected in sweeper efficiencies in table 7). This factor accounts for an incomplete sweeping of streets that can result from parked vehicles or other obstructions, operator inefficiencies, poor pavement conditions, or combinations of these and other factors that likely affect sweeper performance.

Street-sweeping frequency is an important variable in the effectiveness of removing constituent loads that build up on streets between storms. If streets are swept less frequently than it rains, then the effectiveness is decreased because contaminants are potentially washed from the streets prior to removal by sweeping. An optimal street sweeping frequency would provide at least one cleaning between storms. The average dry period between measurable storms, separated by a minimum dry period of $12 \mathrm{hrs}$, recorded at Logan Airport from 1970 through 1995, was 85 hrs; the average dry period between storms increased slightly, to 89 hours, for the months May through October. The average time
Table 7. Efficiencies of street sweepers simulated for removing selected contaminants

[Values are in percent. Best available technology efficiencies are based on highest reported literature values]

\begin{tabular}{lcccc}
\hline Type & $\begin{array}{c}\text { Suspended } \\
\text { solids }\end{array}$ & $\begin{array}{c}\text { Fecal } \\
\text { coliform } \\
\text { bacteria }\end{array}$ & $\begin{array}{c}\text { Total } \\
\text { phos- } \\
\text { phorus }\end{array}$ & $\begin{array}{c}\text { Total } \\
\text { lead }\end{array}$ \\
\hline & 25 & 5 & 5 & 10 \\
Wet vacuum and & 45 & 20 & 20 & 30 \\
regenerative air & & 50 & 50 & 70 \\
$\begin{array}{l}\text { Dry vacuum } \\
\text { Best available }\end{array}$ & 80 & 90 & 90 & 95 \\
technology & 95 & & & \\
\hline
\end{tabular}

since the last $0.10 \mathrm{in}$. of precipitation was about $125 \mathrm{hrs}$ for all storms and the average time since the last $0.20 \mathrm{in}$. of precipitation was about $160 \mathrm{hrs}$ for all storms. Storms with total precipitation volumes greater than 0.25 in., or greater than 0.50 in., had similar antecedent conditions as for all storms. This indicates that, on average, weekly street sweeping may provide contaminant removal prior to storms that are of sufficient size to "wash" the street surfaces.

Six sweeping frequencies (SWMM variable CLFREQ) were simulated in this study - once every $30,15,7,3.5$ days and once daily. Monthly and biweekly cleaning frequencies were evaluated because sweeping at more frequent intervals may not be possible or justified. Cleaning frequencies of less than one week were simulated to evaluate removal rates that are less than the average dry period between storms. The sweeping frequency specified by the model variable CLFREQ is not necessarily the time between sweeping because only dry time steps (runoff volume less than $0.0005 \mathrm{in} / \mathrm{hr}$ ) are counted in the cumulative time since the last sweeping. Thus, the actual time between sweepings can be appreciably longer than that specified by CLFREQ if appreciable runoff is simulated. The number of days since the last cleaning (SWMM variable DSLCL), which only affects the beginning of the model simulation, was set to one half the sweeping frequency. 


\section{Model Limitations}

In the implementation of street sweeping in SWMM, the variable TCLEAN (the time since the last cleaning) is updated at each time step until TCLEAN $=$ CLFREQ (the street cleaning frequency); then TCLEAN is reset to zero. Again, it should be emphasized that CLFREQ is not necessarily the sweeping interval specified by the user because only dry time steps are counted in the cumulative time since the last sweeping. SWMM reinitializes time after sweeping, therefore, constituent buildup immediately following sweeping is characterized by the buildup rate between time zero and CLFREQ, regardless of the load remaining on the street after cleaning. As a result, the simulated contaminant buildup can be faster with street sweeping than without.

For example, the buildup of solids in the street land-use subcatchment with no sweeping and with sweeping every 2 days $($ CLFREQ $=2)$ is illustrated in figure $5 \mathrm{~A}$. Given an initial buildup rate of QFACT(3), the Michaelis-Menton equation then calculates a time-varying buildup rate that asymptotically approaches zero as the built-up load approaches the buildup limit, QFACT(1), as shown for the buildup pattern with no sweeping. This buildup pattern is assumed to represent equilibrium between constituent buildup and dispersion by wind and traffic. When sweeping is simulated, the load is decreased every 2 days by the effective efficiency (street-sweeper efficiency, REFF, times the availability factor, AVSWP), but the buildup following sweeping is the same as the rate from 0 to 2 days regardless of the load remaining on the street. A stair-step pattern results, as shown for the low-efficiency case (fig. 5A), which causes the simulated built-up load with sweeping to exceed the built-up load without sweeping.

A buildup pattern following regular sweeping that does not exceed the suspended solids buildup with no sweeping is
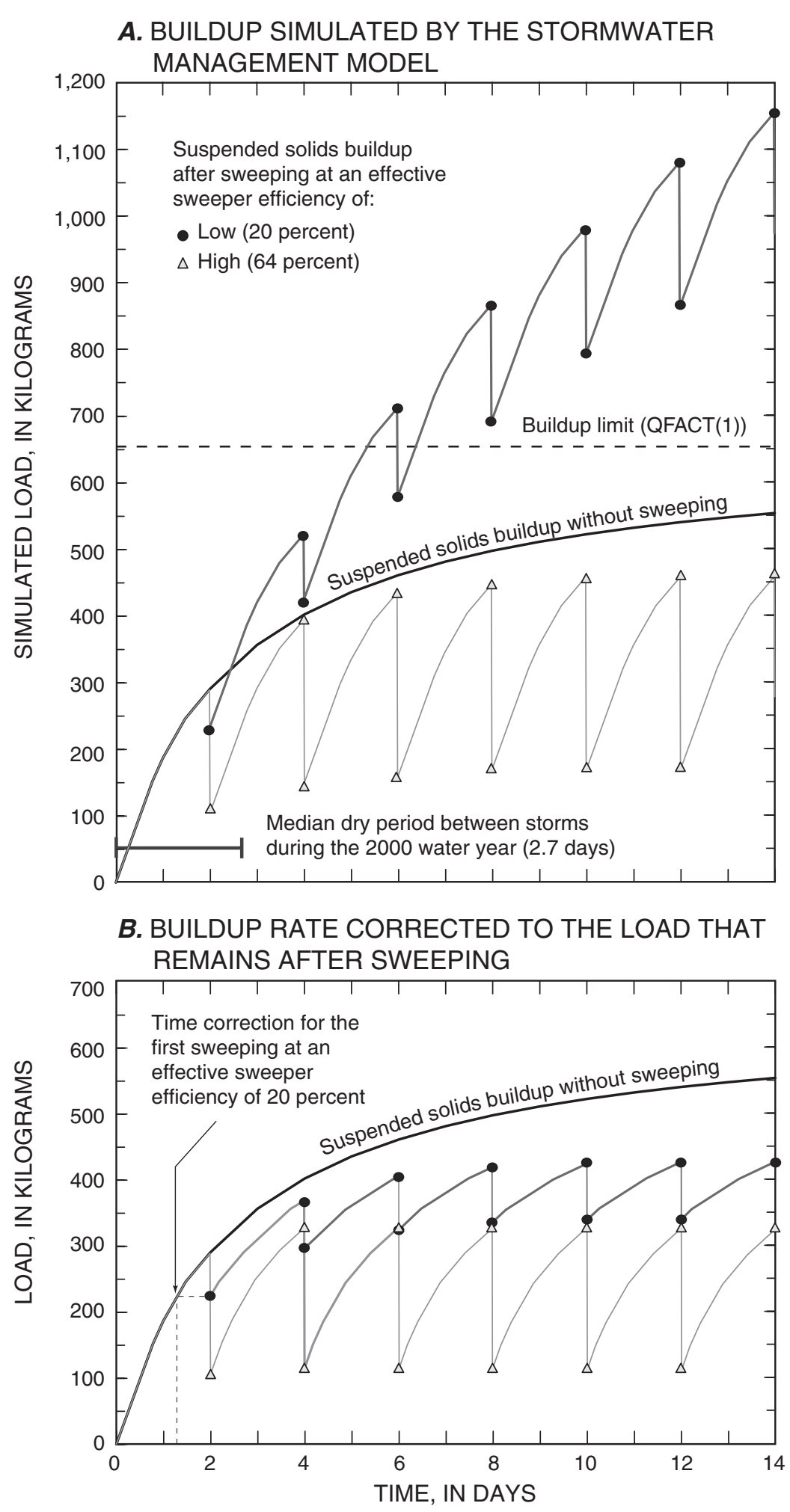

Figure 5. Suspended-solids buildup on streets simulated by the MichaelisMenton method with and without street sweeping at two sweeper efficiencies and 2-day sweeping intervals by the $(A)$ Stormwater Management Model and $(B)$ an adjusted buildup rate corrected to the load that remains after sweeping. 
shown in figure $5 B$. This pattern is based on the assumption that the rate of buildup after sweeping is dependent on the load remaining after sweeping, whereby the time in the Michaelis-Menton equation immediately after sweeping is set to the time at the equivalent buildup load without sweeping. This adjusted time prevents the buildup load with sweeping from exceeding the buildup load without sweeping. After 14 days with no storms, the simulated street solids load with no sweeping was about $550 \mathrm{~kg}$ in the street subcatchment simulated in this study. With street sweeping every 2 days and with no storms, the SWMM simulated load just prior to sweeping on day 14 was about 1,160 and $550 \mathrm{~kg}$ when swept at an effective efficiency of 20 and 64 percent, respectively; the adjusted buildup load (fig. $5 B$ ) was about 430 and $330 \mathrm{~kg}$ when swept at an effective efficiency of 20 and 64 percent, respectively. A similar stair-step pattern would result from sweeping with other buildup functions available in SWMM because the upper load limit increases each time TCLEAN is reset to zero.

As illustrated, resetting time to zero after sweeping can appreciably affect the simulated load, particularly when there is a long dry period between storms, and the sweeping frequency is short. The effect of the model-simulated buildup rate upon the percentage of the load removed by sweeping is minor, however, compared to the percentage that would be obtained from an adjusted buildup rate, for two reasons. First, the percent load removed by sweeping is a relative measure, which is calculated by the swept load divided by the built-up load. Since the swept load is a product of the built-up load and the effective sweeping efficiency, the swept load increases as the built-up load increases. A small difference in the percent load removed results from the model simulated buildup rate relative to the adjusted buildup rate. The SWMM buildup rate is greater than the adjusted buildup rate following sweeping; thus, as time increases since the last sweeping, the difference in the built-up load between the two methods increases, which causes the model to undersimulate the load removed by sweeping compared to what would be calculated by an adjusted buildup rate (shown schematically in fig. 6).

The second factor that minimizes the difference in the percent load removed associated with the two buildup rates is the frequency with which storms punctuate the buildup-sweeping cycle in the Boston area. During the 2000 water year, and during the 1970-2000 period, the median dry period between storms was about the same (2.7 days). Because storms in the Boston area generally are frequent, constituent buildup rarely approaches the asymptote of the buildup curve. Thus, the constituent buildup is typically characterized

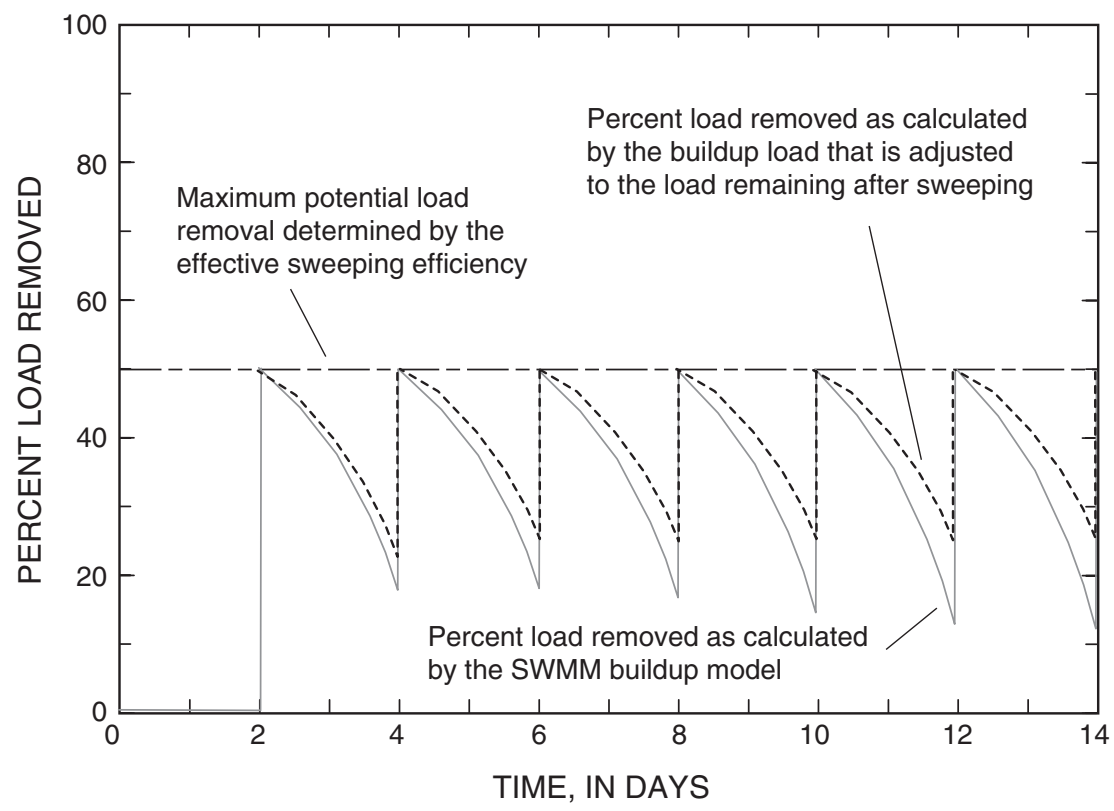

Figure 6. Schematic representation of the percent load removed by street sweeping at 2-day intervals when calculated by the Stormwater Management Model and by a buildup rate adjusted for the load remaining after sweeping. 
by rapid rates that follow storms (similar to the buildup rate that follows sweeping), rather than the slower rates, which characterize later times in the buildup process. The frequent storms result in a minimal difference ( 2.6 percent) between the surface buildup loads simulated with sweeping (once every 2 days at 20 percent effective sweeping efficiency) and the loads that would be buildup with no sweeping, whereas the expected buildup load with sweeping at this frequency and effectiveness would have been about twice the load with no sweeping after 14 days with no storms (fig. 5A).

The buildup following storms, unlike the buildup following sweeping, is calculated by the model on the basis of the load remaining (much like the adjusted buildup described above). This can result in considerable differences in the built-up load relative to the swept load, depending largely on the values used for the washoff variables. Washoff-variable values that cause less built-up load to be removed by storms make more of the load available to sweeping. Conversely, washoff-variable values that cause more built-up load to be removed by storms make less load available to sweeping. The effects of variable values on the removal rates calculated by sweeping are examined in the sensitivity analysis.

\section{A. ANNUAL SUSPENDED-SOLIDS LOADS}

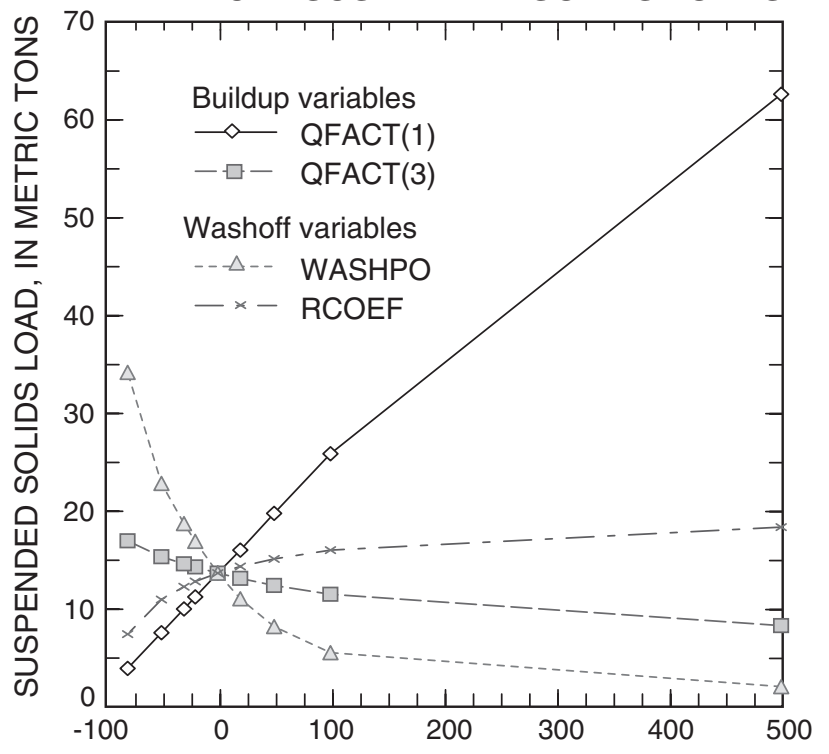

\section{Sensitivity Analysis}

The sensitivity of the simulated suspended solids loads in runoff and the load removed by street sweeping were examined as a function of model buildup and washoff variable values to facilitate interpretation of the model results. One variable value was changed at a time, incrementally, to evaluate its effect on the runoff load and removal by street sweeping. Street sweeping was only evaluated for an effective efficiency of 76 percent (representing the highest sweeper efficiency and an availability factor of 80 percent) at a two-day sweeping frequency. The variables tested included QFACT(1) and QFACT(3), which express rates of constituent buildup, and WASHPO and RCOEF, which express rates of constituent washoff. The values for these variables were increased by $20,50,100$, and 500 percent and then decreased by 30,50 , and 80 percent from the calibrated model values.

Results of the sensitivity analysis (fig. 7) indicate that changes in the annual solids load are about linearly proportional to changes in QFACT(1). The simulated annual solids load was relatively insensitive but inversely related to the value of QFACT(3). The annual solids load increased disproportionately to decreased values of WASHPO; the load initially decreased in

\section{B. PERCENT LOAD REMOVED BY STREET SWEEPING}

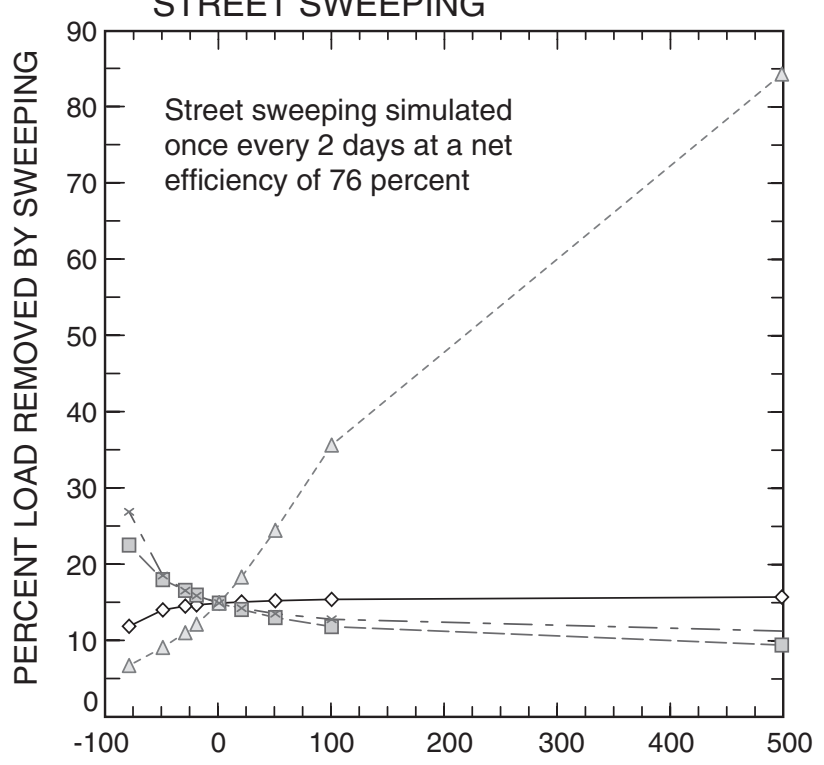

PERCENT CHANGE IN VARIABLE VALUE

Figure 7. Sensitivity of $(A)$ annual suspended-solids loads and $(B)$ percent load removed by street sweeping to buildup and washoff variable values in the Stormwater Management Model. 
rough proportion to increased values of WASHPO, but these decreases taper off at higher values of WASHPO. The annual solids load decreased in rough proportion to values of RCOEF values, but was relatively insensitive to increased values of RCOEF.

This analysis indicates that the suspended solids load and swept load are both highly sensitive to the value of WASHPO. Increasing values of WASHPO cause large increases in the simulated load removal by sweeping. As WASHPO increases, less of the built-up load is removed by storms, particularly small storms; hence, more of the built-up load is available for sweeping, which increases the percent load removed by sweeping. The percent load removed by sweeping also increases as values of QFACT(3) and RCOEF decrease. Decreasing values of RCOEF decreases washoff by storms; this change increases the load available for sweeping, but less drastically than do increases in values of WASHPO. Decreasing QFACT(3) - the initial buildup rate-decreases the built-up load that is divided into the swept load. This diminishes the difference in the built-up load calculated by SWMM compared to that calculated by the adjusted buildup rate following sweeping (fig. 6). The load removed by sweeping is relatively insensitive to changes in QFACT(1).

\section{Simulated Contaminant Removal by Street Sweeping}

SWMM simulations provide a tool to assess various sweeper efficiencies and sweeping frequencies under the dynamics of actual storm and antecedent conditions. Results of simulations of various sweeper efficiencies and sweeping frequencies on the singlefamily land-use subbasin are presented below.

\section{Calibrated-Model Load Removals}

Simulation results for the 24 permutations of sweeper efficiencies and sweeping frequency intervals (fig. 8) generally indicate that less than 10 percent of the total built-up solids and lead loads was removed and less than 5 percent of the built-up fecal coliform bacteria and phosphorus loads was removed at sweeping frequencies of 7 days or longer. The dry-weather load is not included in these removal rates because dry-weather loads were simulated as a constant load originating from ground water and not considered part of the built-up load that is sweepable. The percent load removal by sweeping is calculated by the model as the swept load divided by the total surface buildup. Therefore, to obtain the percent of the total subbasin load removed by sweeping, these values must be multiplied by the fraction of the surface load to the total load. For suspended solids and total lead, the percentage of the total load removed by sweeping is nearly the same because only a small fraction of the total load (4 and 5 percent, respectively) is attributed to dry-weather sources. For fecal coliform bacteria and total phosphorus, the percentage of the total load removed by sweeping is less because dry-weather sources contribute 16 and 30 percent, respectively, to the total load; thus, assuming a 5 percent swept load, the percentage of the total load removed by sweeping is about 4 to 3 percent, respectively.

The percent removal increased markedly at sweeping frequencies less than 7 days for suspended solids and total lead; the percent removal of fecal coliform bacteria and total phosphorus also increases at sweeping frequencies less than 3.5 days, but not as dramatically as that for solids and lead. This result underscores the importance of sweeping frequency relative to the average inter-storm dry periods-if the sweeping interval is greater than the average interstorm dry period, there is little opportunity to remove contaminants regardless of the sweeping efficiency.

Simulation results suggest that street sweeping, even at the highest efficiency (effective sweeper efficiencies of 76 percent for suspended solids and lead and 72 percent for fecal coliform bacteria and total phosphorus), removes only a small fraction of the total load unless intensive sweeping programs are implemented. Simulations indicate less than a 5 percent load reduction of fecal coliform bacteria and less than an 8 percent load reduction for total phosphorus for sweeping with the highest efficiency sweeper once per day. The lower removal rates for fecal coliform bacteria and total phosphorus relative to the removal rates for suspended solids and total lead are attributed to the lower sweeping efficiencies and higher perviousarea loadings for fecal coliform bacteria and total phosphorus.

These simulation results are consistent with the findings of Pitt $(1978,1985)$, who found load reductions of solids in the range of 5 to 10 percent for NURP-era sweepers. Sutherland and Jelen (1997) report considerably higher simulated removal rates, 


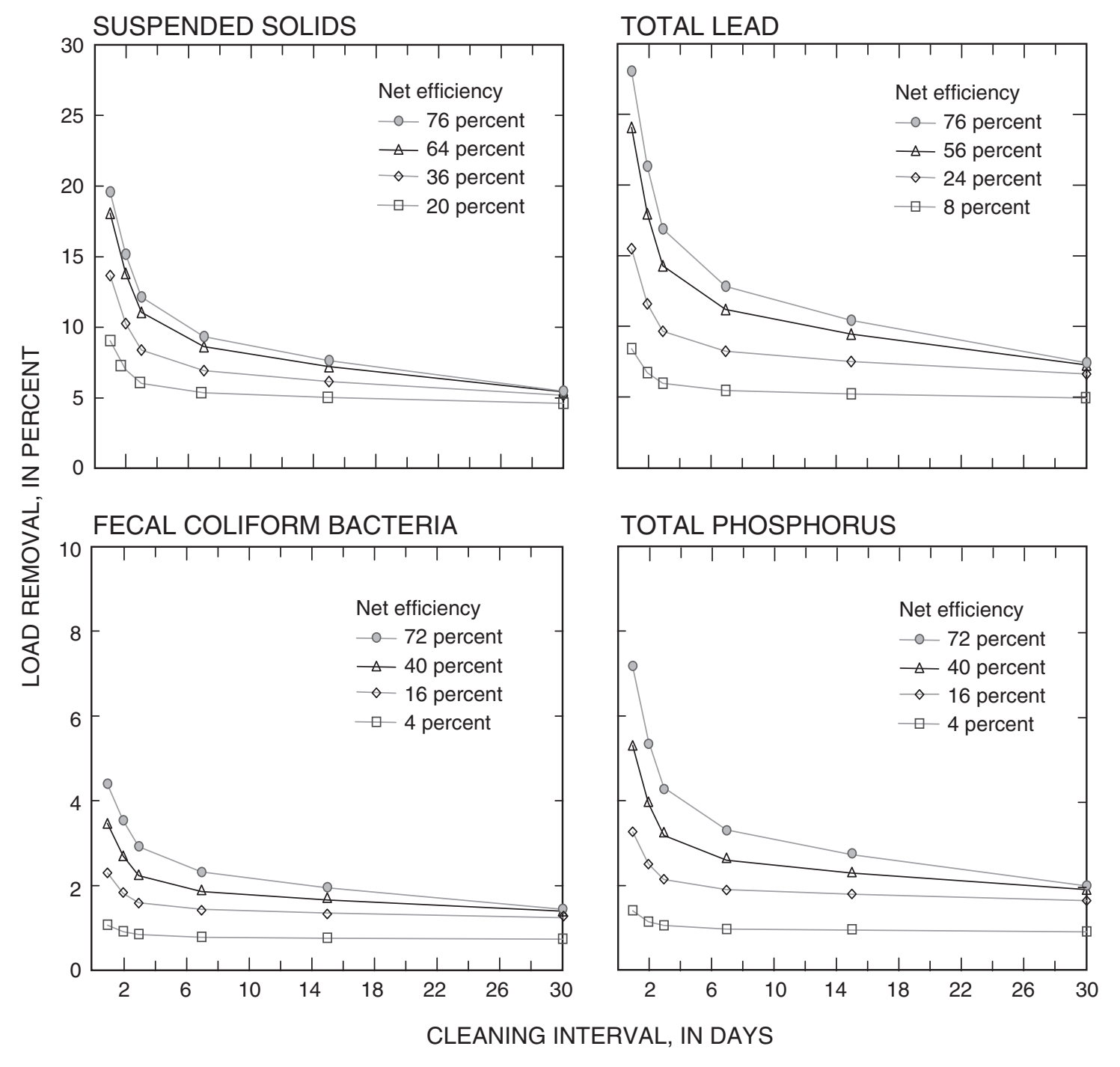

Figure 8. Simulated constituent-load removal for various sweeper efficiencies at selected sweeping intervals in the singlefamily land-use subbasin, lower Charles River Watershed, Massachusetts, 2000 water year.

which they calculated using the SIMPTM model they developed. Their simulations indicate that sweeping twice per month and twice per week yielded solids load removals, respectively, of 20 to 30 percent for new mechanical sweepers, 50 to 70 percent for regenerative air sweepers, and 60 to nearly 90 percent for dryvacuum sweepers. Sutherland and Jelen (1997) did not provide information on the efficiencies of the sweepers simulated, the street availability factor, frequency of storms, or the model calibration; thus, their findings cannot be related to the conditions simulated in this study. Undoubtedly, sweeper performance has improved markedly since completion of the NURP studies, but little independent information is available to assess whether these advanced sweepers can help achieve the desired water-quality objectives.

\section{Alternative-Model Load Removals}

Given the sensitivity of the effectiveness of sweeping to the models' variable values, especially WASHPO, an alternative model of the single-family land-use subbasin was constructed for simulating 
suspended solids buildup and washoff. The alternative model allowed less washoff of builtup loads during small storms. The variable WASHPO was increased from 1.85 to 3.0 (about a 60 percent increase) and the variable RCOEF was decreased from 10.7 to 2.0 (about a 80 percent decrease). This model was calibrated by adjusting the buildup variable values QFACT(1) and QFACT(3) until the simulated annual load matched the estimated annual load.

These model changes increased the percentage of suspended solids load removed by street sweeping about four-fold; annual suspended solids removal increased from 15 percent to 66 percent by sweeping every 2 days at an effective efficiency of 76 percent. A similar improvement in the load removal could be expected over the previous model results for the other constituents, sweeping frequencies, and sweeper efficiencies.

Although the alternative model was calibrated to the total annual load, the model fit for the eight sampled storms was not as good as that for the previous model. The percent difference between measured and simulated suspended solids loads increased for five of the sampled storms, but decreased for three of the storms (table 8), all of which occurred in July. This indicates that the effects of sweeping may not be as small as first simulated, because buildup and washoff processes may not be described by a single set of model values (SWMM does not allow variable values to change seasonally). The alternative model values, which markedly increased the simulated constituent load removal by sweeping (table 9), appear to better represent these processes during the mid-summer. The potential reduction in stormwater contaminant loads achieved by street sweeping in the summer is of considerable importance, because recreational use of the lower Charles River is greatest at this time.

This analysis indicates that street sweeping should not be discounted as a stormwaterquality management practice. Only through direct field investigation of the relevant processes can the effectiveness of street sweeping
Table 8. Measured and simulated loads of suspended solids for sampled storms, single-family land-use subbasin, 2000 water year, lower Charles River Watershed, Massachusetts

[AE, average error; RMS, root mean square error; kg, kilograms]

\begin{tabular}{|c|c|c|c|c|c|}
\hline \multirow{2}{*}{ Storms } & \multicolumn{2}{|c|}{ Load (kg) } & \multirow{2}{*}{$\begin{array}{c}\text { Percent } \\
\text { difference }\end{array}$} & \multirow{2}{*}{$\begin{array}{l}\text { Alternative } \\
\text { model load } \\
\quad(\mathrm{kg})\end{array}$} & \multirow{2}{*}{$\begin{array}{c}\text { Percent } \\
\text { difference }\end{array}$} \\
\hline & Measured & $\begin{array}{c}\text { Calibrated } \\
\text { model }\end{array}$ & & & \\
\hline & 375 & 348 & -7.0 & 146 & -61 \\
\hline 4-09-2000 & 307 & 262 & -15 & 33 & -89 \\
\hline \multirow[t]{2}{*}{$5-18-2000$} & 96 & 116 & 22 & 8 & -92 \\
\hline & 497 & 398 & -20 & 300 & -40 \\
\hline $6-06-2000$ & 1,210 & 1,120 & -8.0 & 1,860 & 54 \\
\hline \multirow[t]{2}{*}{$7-09-2000$} & 170 & 297 & 74 & 62 & -64 \\
\hline & 28.4 & 88.7 & 210 & 10 & -66 \\
\hline $7-26-2000$ & 311 & 396 & 27 & 343 & 10 \\
\hline RMS & & & & & \\
\hline
\end{tabular}

Table 9. Percent removal of constituent loads by street sweeping simulated with the highest efficiency sweeper once every 2 days with the calibrated and an alternative Stormwater Management Model in the single-family land-use subbasin, lower Charles River Watershed, Massachusetts

\begin{tabular}{ccccc}
\hline $\begin{array}{c}\text { Sweeping } \\
\text { frequency } \\
\text { (days) }\end{array}$ & $\begin{array}{c}\text { Suspended } \\
\text { solids }\end{array}$ & $\begin{array}{c}\text { Fecal } \\
\text { coliform }\end{array}$ & $\begin{array}{c}\text { Total } \\
\text { phosphorus }\end{array}$ & $\begin{array}{c}\text { Total } \\
\text { lead }\end{array}$ \\
\cline { 3 - 4 } & \multicolumn{4}{c}{ Calibrated model } \\
& 5.4 & 1.4 & 2.0 & 7.5 \\
15 & 7.6 & 1.9 & 2.7 & 10 \\
7 & 9.3 & 2.3 & 3.3 & 13 \\
& 12 & 2.9 & 4.3 & 17 \\
2 & 15 & 3.5 & 5.5 & 21 \\
1 & 20 & 4.3 & 7.2 & 28 \\
& & Alternative model & \\
& & & & 17 \\
15 & 17 & 1.7 & 2.8 & 23 \\
7 & 24 & 2.3 & 3.9 & 29 \\
& 29 & 2.8 & 4.7 & 38 \\
1 & 39 & 3.5 & 6.2 & 49 \\
\hline & 49 & 4.3 & 7.8 & 64 \\
\hline
\end{tabular}


as a water-quality control be established. The effectiveness of this type of control could be evaluated by independently measuring built-up loads, swept loads, and stormwater loads under a range of conditions (including pavement conditions), sweeper technologies and operator practices, and a range of storms that represent different seasons, sizes and intensities. Concurrent modeling efforts would improve understanding of buildup, washoff, and sweeping processes in the watershed. This information is needed to determine, with reasonable certainty, if street sweeping can provide theload reductions necessary to meet water-quality objectives in the lower Charles River.

\section{POTENTIAL EFFECTS OF STRUCTURAL CONTROLS AND STREET SWEEPING ON LOADS TO THE LOWER CHARLES RIVER}

The potential contaminant load reductions obtainable by implementing structural controls in the lower Charles River Watershed were estimated by assuming that a similar matrix of control types could be put into practice at the density and with proportionally similar contributing areas to the Village Brook Subbasin. Constituent removal rates obtained in the Village Brook Subbasin (table 3) were then applied to each of the major lower Charles River subbasins (fig. 1)—Laundry Brook, Faneuil Brook, Muddy River, Stony Brook, and the ungaged area defined in studies by Zarriello and Barlow (2002) and Breault and others (2002).

Implementing structural controls in the Village Brook Subbasin in accordance with the CWP recommendations (table 2) would, on average, have the greatest effect on loads of suspended solids and the least effect on loads of fecal coliform bacteria. Overall, structural controls are estimated to reduce total loads by about 15 percent for suspended solids loads and about 6 percent for fecal coliform bacteria at the outlet of the Village Brook Subbasin. Total phosphorus load reductions are affected by dry-weather loads, which are proportionally greater than the dry-weather loads for the other constituents considered; dry-weather loads are assumed to be unaffected by structural controls. This is believed to be a reasonable assumption because the structural controls recommended by the CWP are designed to treat surface runoff and the dry-weather loads are believed to originate from sources such as illicit connections that are unaffected by the structural controls considered.

Removal efficiencies of contaminants by street sweeping from model simulations of the single-family residential land-use subbasin were extrapolated to other areas of the lower Charles River Watershed by two methods that weighted the simulated removal rates differently. The first method was based on the assumption that the load available for sweeping in other subbasins of the lower Charles River Watershed is proportional to the ratio of road density in the subbasin to that in the single-family land-use subbasin. This ratio constitutes the "road-density-weighting factor" shown in table 10; the ratio is multiplied by the removals simulated for various sweeping frequencies and efficiencies to estimate contaminant removal in each of the major subbasins.

The second method used to weight the simulated contaminant removal by sweeping was based on the assumption that the contaminant load from streets is similar to that in the single-family land-use subbasin (load per unit street length) and that the subbasin load available for sweeping is a function of the street load relative to the total subbasin load. Street loads in each of the other subbasins were estimated from their total road miles (table 10) and the annual street load per mile obtained from the calibrated model. Computed contaminant yields in the single-family land-use subbasin were $3.61 \mathrm{~kg} / \mathrm{d} / \mathrm{mi}$ for suspended solids, 13.95 million CFU/d/mi for fecal coliform bacteria, $14 \mathrm{~g} / \mathrm{d} / \mathrm{mi}$ for total phosphorus, and $2.05 \mathrm{~g} / \mathrm{d} / \mathrm{mi}$ for total lead.

Table 10. Subbasin street length and density, lower Charles River Watershed, Massachusetts

$\left[\mathrm{mi} / \mathrm{mi}^{2}\right.$, miles per square mile]

\begin{tabular}{|c|c|c|c|}
\hline \multirow{2}{*}{ Subbasin } & \multicolumn{2}{|c|}{ Street } & \multirow{2}{*}{$\begin{array}{c}\text { Road- } \\
\text { density } \\
\text { weighting } \\
\text { factor }\end{array}$} \\
\hline & $\begin{array}{l}\text { Length } \\
\text { (miles) }\end{array}$ & $\begin{array}{l}\text { Density } \\
\left(\mathrm{mi} / \mathrm{mi}^{2}\right)\end{array}$ & \\
\hline Single family & 9.8 & 28 & 1.00 \\
\hline Laundry Brook & 97 & 20 & .71 \\
\hline Faneuil Brook & 30 & 21 & .75 \\
\hline Muddy River & 115 & 21 & .75 \\
\hline Stony Brook & 252 & 21 & .75 \\
\hline Ungaged area & 290 & 23 & .82 \\
\hline $\begin{array}{l}\text { Lower Charles River } \\
\text { Watershed }\end{array}$ & 784 & 21 & .75 \\
\hline
\end{tabular}


The street-weighting factor was calculated from the estimated street contaminant load (table 11) divided by the subbasin load averaged from the different estimation techniques reported by Breault and others (2002). In some cases, the street load divided by the subbasin load is greater than one because of the inaccuracies of this extrapolation method; in these instances, the weighting factor was assigned a value of one. This factor was used as a multiplier to adjust the simulated load removal by sweeping at various frequencies and efficiencies.

\section{Water Year 2000}

Annual contaminant loads to the lower Charles River from non-CSO sources below Watertown Dam reported by Breault and others (2002) decreased by hypothetical CWP-recommended structural controls. Estimated load reductions based on the median structural-control removal efficiencies decreased by 17 percent for suspended solids, 15 percent for total lead, 13 percent for fecal coliform bacteria, and 9.7 percent for total phosphorus (table 12). The percent load reductions from implementing structural controls are somewhat less when upstream loads (Charles River Watershed above Watertown Dam) are considered (table 12). Loads from the watershed above Watertown Dam are assumed to remain constant, however.
Annual load reductions to the lower Charles River that could be expected from street sweeping in the lower watershed at various efficiencies and frequencies are shown in figure 9. These load reductions are based on results of the calibrated model simulations of the single-family land-use subbasin extrapolated to the entire lower watershed by the street-density-ratio method. Load reductions (as a percentage of the total annual load excluding load from the upper watershed) ranged from about 3.5 to 15 percent for suspended solids, 0.5 to 3.3 percent for fecal coliform bacteria, 0.7 to 5.5 percent for total phosphorus, and 3.8 to 21 percent for total lead, estimated by the street-density-ratio method. Load reductions (excluding loads from the upper watershed) estimated by the ratio of the street load to the subbasin load were somewhat less-2.7 to 12 percent for suspended solids, 0.3 to 2.0 percent for fecal coliform bacteria, 0.5 to 3.8 percent for total phosphorus, and 1.6 to 8.8 percent for total lead.

Only a small fraction of the total annual load to the lower Charles River is removed by street sweeping if the load contribution from the upper watershed is included. At best, the total annual contaminant load removed by intensive street sweeping (once per day), with the best available technology, is only 4 percent for suspended solids, 2 percent for fecal coliform bacteria, about 1 percent for total phosphorus, and about 8 percent for total lead. These load reductions are based on results of the calibrated-model load reductions from

Table 11. Street and subbasin contaminant loads used to calculate the weighting factor for estimating potential contaminant removal by street sweeping in 2000 water year, lower Charles River Watershed, Massachusetts

\begin{tabular}{|c|c|c|c|c|c|c|c|c|c|c|c|c|}
\hline \multirow{2}{*}{ Subbasin } & \multicolumn{3}{|c|}{$\begin{array}{l}\text { Suspended solids } \\
\text { (metric tons/yr) }\end{array}$} & \multicolumn{3}{|c|}{$\begin{array}{l}\text { Fecal coliform } \\
\text { (TCFU/yr) }\end{array}$} & \multicolumn{3}{|c|}{$\begin{array}{c}\text { Total phosphorus } \\
\text { (kg/yr) }\end{array}$} & \multicolumn{3}{|c|}{$\begin{array}{l}\text { Total lead } \\
\text { (g/yr) }\end{array}$} \\
\hline & Street & $\begin{array}{l}\text { Sub- } \\
\text { basin }\end{array}$ & $\begin{array}{l}\text { Weighting } \\
\text { factor }\end{array}$ & Street & $\begin{array}{l}\text { Sub- } \\
\text { basin }\end{array}$ & $\begin{array}{l}\text { Weighting } \\
\text { factor }\end{array}$ & Street & $\begin{array}{l}\text { Sub- } \\
\text { basin }\end{array}$ & $\begin{array}{l}\text { Weighting } \\
\text { factor }\end{array}$ & Street & $\begin{array}{l}\text { Sub- } \\
\text { basin }\end{array}$ & $\begin{array}{l}\text { Weighting } \\
\text { factor }\end{array}$ \\
\hline \multirow{3}{*}{ Faneuil Brook } & 127 & 64 & 1.00 & & 279 & 1.00 & & 317 & 1.00 & & 44 & 1.00 \\
\hline & 39 & 50 & .78 & & 389 & .39 & & 123 & 1.00 & & 24 & .96 \\
\hline & 151 & 335 & .45 & & 1,570 & .37 & & 1,570 & .38 & & 287 & .30 \\
\hline \multirow[t]{2}{*}{ Stony Brook } & 332 & 673 & .49 & & 2,740 & .47 & & 2,130 & .62 & & 813 & .23 \\
\hline & 382 & 242 & 1.00 & & 1,080 & 1.00 & & 1,200 & 1.00 & & 182 & 1.00 \\
\hline $\begin{array}{l}\text { Lower Charles } \\
\text { River Watershed }\end{array}$ & 1,031 & 1,364 & .76 & & 6,058 & .66 & & 5,340 & .77 & & 1,350 & .44 \\
\hline
\end{tabular}


Table 12. Estimated range in the percent decrease in annual loads by hypothetical structural controls, lower Charles River Watershed, Massachusetts

[The load from the upper watershed is assumed to remain constant]

\begin{tabular}{|c|c|c|c|c|}
\hline \multirow[b]{2}{*}{ Constituent } & \multicolumn{4}{|c|}{ Structural control removal efficiency } \\
\hline & $\begin{array}{l}\text { Lower } \\
\text { quartile }\end{array}$ & Median & $\begin{array}{c}\text { Upper } \\
\text { quartile }\end{array}$ & Average \\
\hline
\end{tabular}

Lower Charles River Watershed Load (excludes load above Watertown Dam)

$\begin{array}{lcccc} & 14 & 17 & 18 & 15 \\ \text { Fecal coliform } & 7.5 & 13 & 16 & 6.2 \\ \text { Total phosphorus } & 5.8 & 9.7 & 13 & 8.6 \\ \text { Total lead } & 8.9 & 15 & 17 & 12\end{array}$

Entire Charles River Watershed (includes load above Watertown Dam)

\begin{tabular}{lllll} 
& 3.7 & 4.5 & 4.9 & 3.9 \\
Fecal coliform & 4.6 & 7.8 & 9.7 & 3.8 \\
Total phosphorus & 1.0 & 1.6 & 2.2 & 1.5 \\
Total lead & 3.4 & 5.6 & 6.7 & 4.8 \\
\hline
\end{tabular}

street sweeping in the single-family land-use subbasin and the street-density-ratio extrapolation method (table 13).

In contrast, the alternative model developed for the single-family land-use subbasin shows an increased effectiveness for the highest efficiency sweeper of about threefold for suspended solids, 20 percent for fecal coliform bacteria, 40 percent for total phosphorus, and twofold for total lead. The alternative model indicated a slightly better fit than the original model for measured storms in the summer months; hence, the higher removal rates could be realized if the alternative model buildup and washoff patterns are representative of actual conditions.

The constituent-load reductions to the lower Charles River by combined hypothetical structural controls and street sweeping were estimated for a range of BMP performances (table 14). Load reductions are given as percentages of the wet weather load and total load from non-CSO sources below Watertown Dam and as percentages of the entire watershed load (includes the load from above Watertown Dam). A range that provides reasonable bounds on the constituent load that could be removed by the practices is presented because of the inherent variability and uncertainty of removal efficiencies. The estimated lower load reductions are based on the lower quartile of the structural-control removal rates combined with the load removed by street sweeping once every 30 days, as simulated by the calibrated model with lowefficiency sweepers and extrapolated by the street-loadto-subbasin-load method. The estimated upper load reductions are based on the upper quartile of the structural-control removal rates combined with the load removed by street sweeping once per week, as simulated by the alternative model with the best available technology sweepers and extrapolated by the streetdensity-ratio method. Weekly sweeping was chosen as an upper constituent removal estimate for street cleaning because water-quality managers considered this the most frequent interval that could be reasonably expected by communities (Mark Voorhees, U.S. Environmental Protection Agency and Kevin Brander, Massachusetts Department of Environmental Protection, oral commun., 2001). The average estimated load reductions are based on the medium structural-control removal rates combined with the load removed by street sweeping with high-efficiency sweepers once every 2 weeks; the average swept-load reductions reflect the average removal rates simulated by the calibrated model and alternative model at this sweeper efficiency and frequency and the average extrapolated load estimate. This range of removal efficiencies was applied to the stormwater portion of the total annual load because these practices are assumed not to affect the dry-weather load.

The upper estimated load reductions by structural controls and street sweeping indicate that these practices can achieve 44 and 34 percent reductions of suspended solids and total lead, respectively, as a percentage of the total load from non-CSO sources below Watertown Dam. Phosphorus and fecal coliform bacteria loads decreased, at best, by 14 and 17 percent, respectively, as a percentage of the total load from nonCSO sources below Watertown Dam. The estimated load reductions were slightly higher for all constituents and all BMP performances as a percentage of wetweather load because the dry-weather load, which generally constituted a small percentage of the total load, was considered to be unaffected by the BMP practices considered. Of the constituents examined, the percent load reduction by BMPs for total phosphorus for wet-weather loads increased the most relative to the total loads, because of its relatively high percent of dry-weather load to total load.

The estimated lower load reductions, and load reductions as a percentage of the entire watershed load (includes the Charles River load above Watertown 


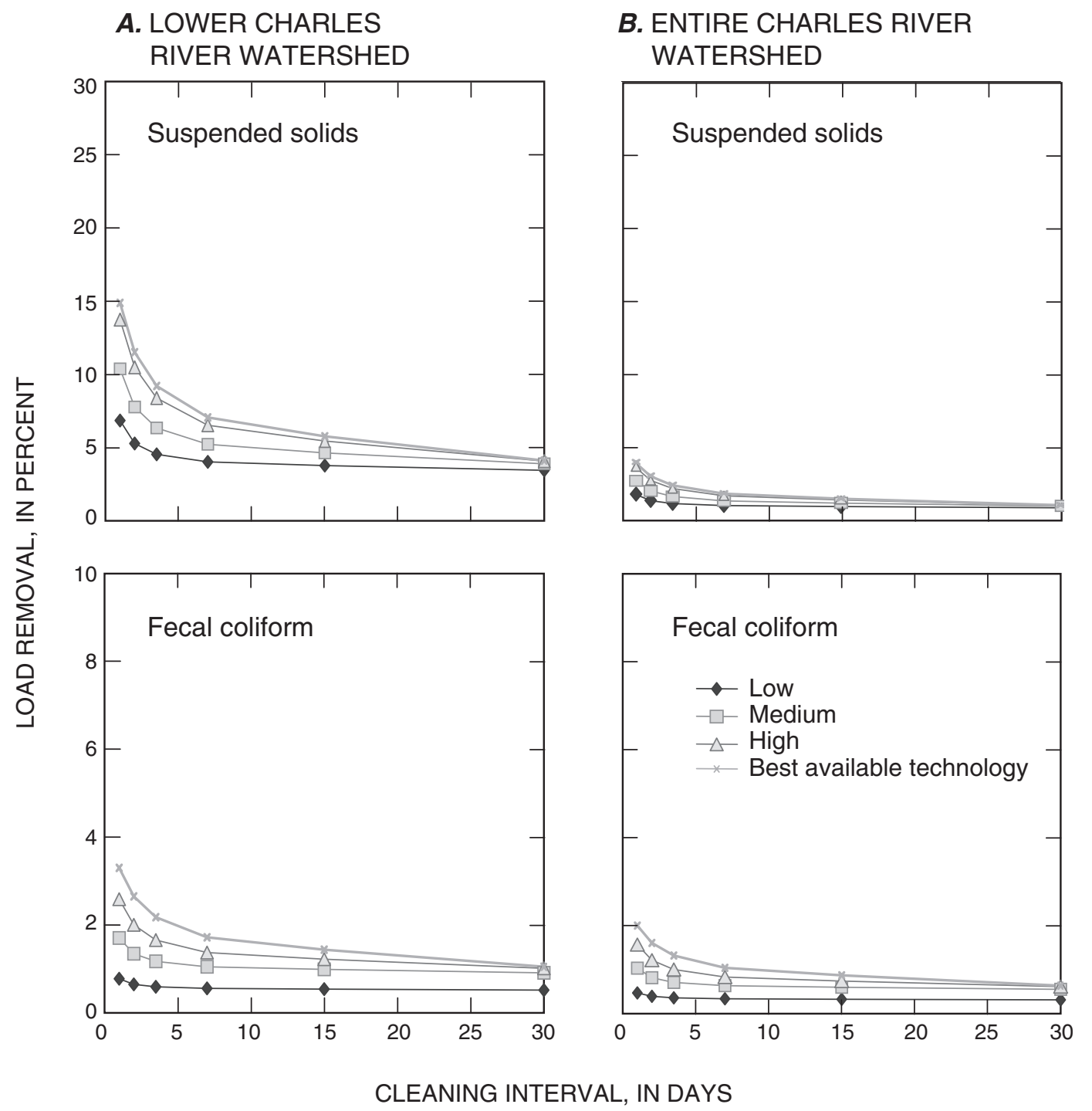

Figure 9. Estimated percent load reduction for the 2000 water year by street sweeping at various efficiencies and frequencies for the $(A)$ lower Charles River (excludes the loads above Watertown Dam) and $(B)$ the entire Charles River Watershed, Massachusetts (estimated by the street density ratio).

Dam) are appreciably less than previously stated as percentages of the load reduction from non-CSO sources below Watertown Dam. For example, the lower estimated reduction of total phosphorus was only 1.0 percent of total load. The relative contributions of contaminant loads from various sources indicate that, for suspended solids and total phosphorus, most of the load is from the upper watershed, and only a small fraction of the load would be removed by implementation of BMP practices in the watershed below Watertown Dam. This is particularly evident for the total phosphorus load (fig. 10), which is dominated by upstream, dry-weather sources. Although most of the
non-CSO fecal coliform bacteria contamination to the Charles River is from sources below Watertown Dam, the BMP practices examined would likely have only a modest effect on these sources, when considered on an annual basis. Nevertheless, BMP implementation could produce substantial water-quality benefits in the lower Charles River near the stormwater outfalls, during and immediately after storm events. These water-quality benefits would be most easily quantified by incorporating the simulated load reductions from BMP implementation into a receiving-water model of the lower Charles River. 
A. LOWER CHARLES

RIVER WATERSHED-Continued

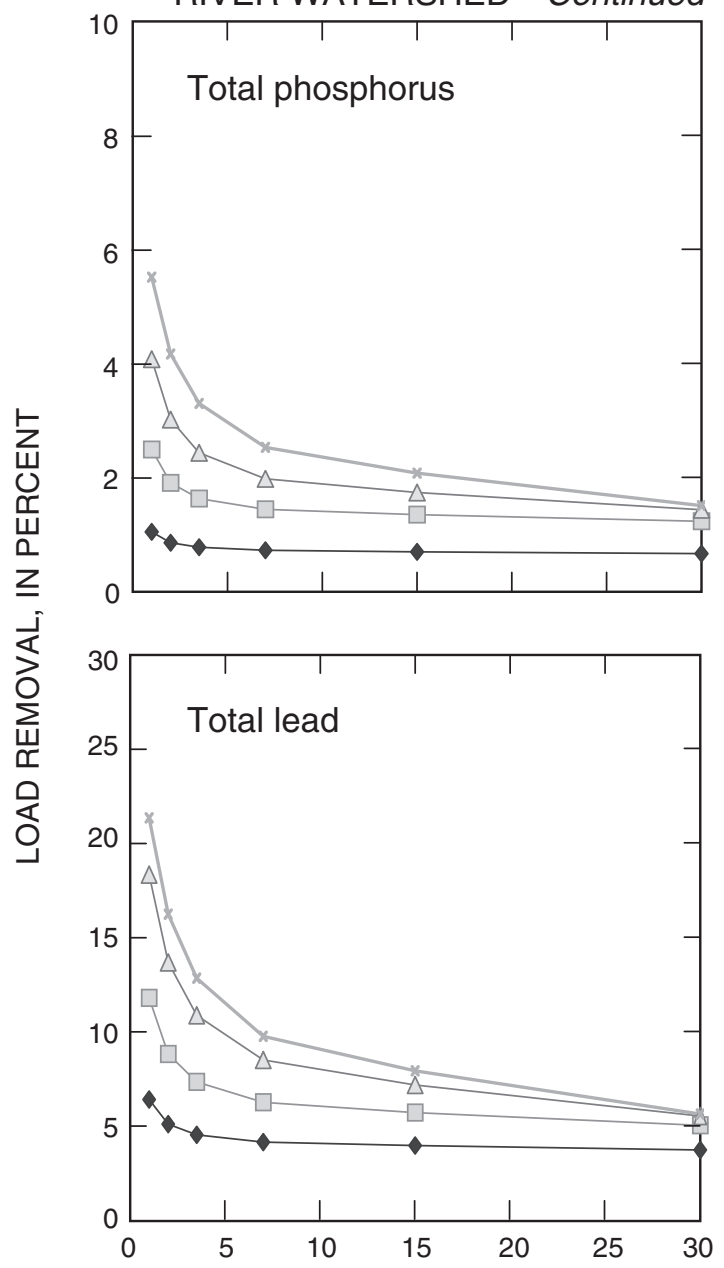

B. ENTIRE CHARLES RIVER

WATERSHED-Continued
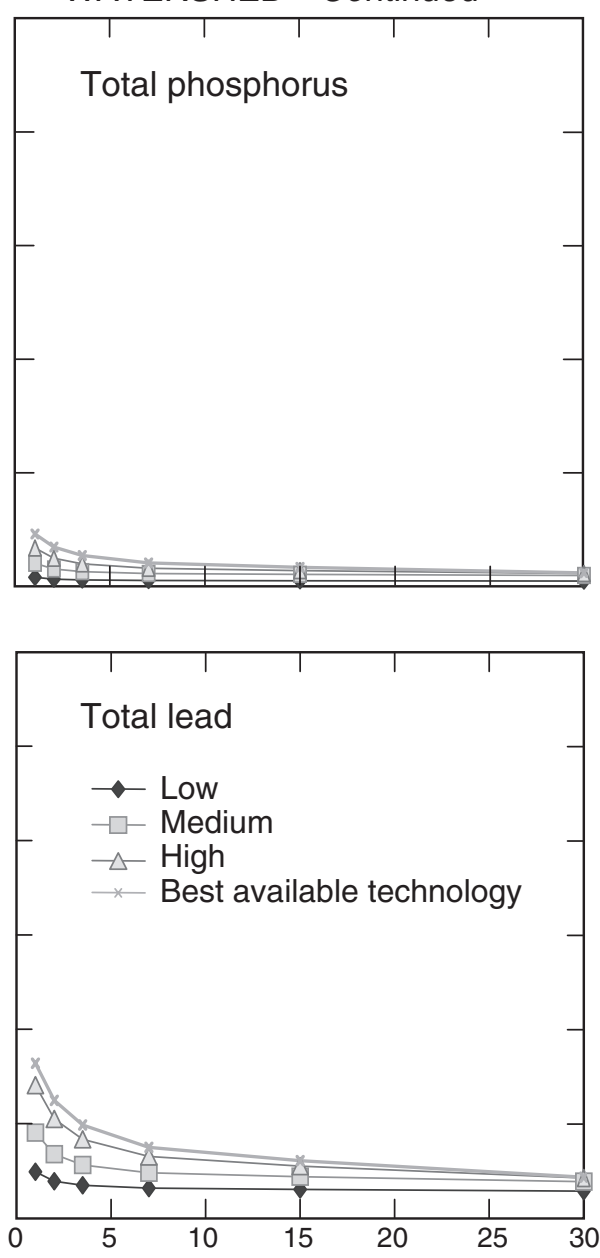

CLEANING INTERVAL, IN DAYS

Figure 9. Estimated percent load reduction for the 2000 water year by street sweeping at various efficiencies and frequencies for the $(A)$ lower Charles River (excludes the loads above Watertown Dam) and $(B)$ the entire Charles River Watershed, Massachusetts (estimated by the street density ratio)—Continued. 
Table 13. Simulated percent annual-load reductions to the lower Charles River, Massachusetts, by street sweeping with the highest efficiency sweepers at various sweeping intervals and the $(A)$ calibrated model and $(B)$ an alternative model

\begin{tabular}{|c|c|c|c|c|c|c|c|c|}
\hline \multirow{2}{*}{$\begin{array}{l}\text { Sweeping } \\
\text { frequency } \\
\text { (days) }\end{array}$} & \multicolumn{4}{|c|}{$\begin{array}{l}\text { Percent load reduction from the } \\
\text { lower Charles River Watershed }\end{array}$} & \multicolumn{4}{|c|}{$\begin{array}{l}\text { Percent load reduction from the } \\
\text { entire Charles River Watershed }\end{array}$} \\
\hline & $\begin{array}{l}\text { Suspended } \\
\text { solids }\end{array}$ & $\begin{array}{c}\text { Fecal } \\
\text { coliform } \\
\text { bacteria }\end{array}$ & $\begin{array}{c}\text { Total } \\
\text { phosphorus }\end{array}$ & Total lead & $\begin{array}{l}\text { Suspended } \\
\text { solids }\end{array}$ & $\begin{array}{c}\text { Fecal } \\
\text { coliform } \\
\text { bacteria }\end{array}$ & $\begin{array}{c}\text { Total } \\
\text { phosphorus }\end{array}$ & Total lead \\
\hline
\end{tabular}

\section{A. CALIBRATED MODEL}

\begin{tabular}{|c|c|c|c|c|c|c|c|}
\hline \multicolumn{8}{|c|}{ Estimated constituent removal by the street-density ratio method } \\
\hline 30 & 4.1 & 1.1 & 1.5 & 5.7 & 0.6 & 0.3 & 2.2 \\
\hline 15 & 5.8 & 1.4 & 2.1 & 8.0 & .9 & .4 & 3.1 \\
\hline 7 & 7.1 & 1.7 & 2.5 & 9.8 & 1.0 & .4 & 3.8 \\
\hline 3.5 & 9.2 & 2.2 & 3.3 & 13 & 1.3 & 6 & 5.0 \\
\hline 2 & 12 & 2.7 & 4.2 & 16 & 1.6 & .7 & 6.3 \\
\hline 1 & 15 & 3.3 & 5.5 & 21 & 2.0 & .9 & 8.2 \\
\hline \multicolumn{8}{|c|}{ Estimated constituent removal by the street load to subbasin-load ratio method } \\
\hline 30 & 3.3 & .6 & 1.0 & 2.3 & .4 & .2 & .9 \\
\hline 15 & 4.6 & .9 & 1.4 & 3.3 & .5 & .2 & 1.3 \\
\hline 7 & 5.6 & 1.0 & 1.7 & 4.0 & .6 & .3 & 1.6 \\
\hline 3.5 & 7.3 & 1.3 & 2.2 & 5.3 & .8 & .4 & 2.0 \\
\hline 2 & 9.1 & 1.6 & 2.8 & 6.7 & 1.0 & .5 & 2.6 \\
\hline 1 & 12 & 2.0 & 3.8 & 8.8 & 1.2 & .6 & 3.4 \\
\hline \multicolumn{8}{|c|}{ B. ALTERNATIVE MODEL ${ }^{1}$} \\
\hline \multicolumn{8}{|c|}{ Estimated constituent removal by the street-density ratio method } \\
\hline 30 & 13 & 1.3 & 2.2 & 13 & 0.8 & 0.4 & 5 \\
\hline 15 & 18 & 1.8 & 3.0 & 18 & 1.1 & .5 & 7 \\
\hline 7 & 22 & 2.1 & 3.6 & 22 & 1.3 & 6 & 8 \\
\hline 3.5 & 30 & 2.7 & 4.7 & 29 & 1.6 & .8 & 11 \\
\hline 2 & 37 & 3.2 & 6.0 & 37 & 2.0 & 1.0 & 14 \\
\hline 1 & 48 & 4.0 & 7.8 & 49 & 2.4 & 1.3 & 19 \\
\hline \multicolumn{8}{|c|}{ Estimated constituent removal by the street load to subbasin-load ratio method } \\
\hline 30 & 10 & .8 & 1.5 & 5.2 & .5 & .2 & 2.0 \\
\hline 15 & 14 & 1.1 & 2.0 & 7.3 & .6 & .3 & 2.8 \\
\hline 7 & 18 & 1.3 & 2.5 & 9.1 & .8 & .4 & 3.5 \\
\hline 3.5 & 23 & 1.6 & 3.2 & 12 & 1.0 & .5 & 4.6 \\
\hline 2 & 29 & 1.9 & 4.0 & 15 & 1.2 & .7 & 5.9 \\
\hline 1 & 38 & 2.4 & 5.3 & 20 & 1.5 & .9 & 7.8 \\
\hline
\end{tabular}

${ }^{1}$ Entire watershed includes loads from above Watertown Dam. 
Table 14. Percent annual-load reductions by combined hypothetical structural controls and street-sweeping practices, lower Charles River Watershed, Massachusetts

[Lower: Lower estimate based on lower quartile of structural control removal rate and sweeping once every 30 days with low-efficiency sweepers. Average: Average estimate based on medium structural control removal rate and sweeping once every two weeks with high-efficiency sweepers. Upper: Upper estimate based on upper quartile of structural control removal rate and sweeping once a week with best available technology sweepers. CSO, combined sewer overflow]

\begin{tabular}{|c|c|c|c|}
\hline \multirow{2}{*}{ Constituent } & \multicolumn{3}{|c|}{ Percent load reduction } \\
\hline & Lower & Average & Upper \\
\hline \multicolumn{4}{|c|}{$\begin{array}{c}\text { Percentage of non-CSO wet-weather load } \\
\text { below Watertown Dam }\end{array}$} \\
\hline & 15 & 25 & 46 \\
\hline Fecal coliform & 7.9 & 14 & 18 \\
\hline Total phosphorus & 6.7 & 12 & 19 \\
\hline Total lead & 11 & 22 & 35 \\
\hline \multicolumn{4}{|c|}{$\begin{array}{l}\text { Percentage of non-CSO total load } \\
\text { below Watertown Dam }\end{array}$} \\
\hline & 14 & 24 & 44 \\
\hline Fecal coliform & 7.5 & 13 & 17 \\
\hline Total phosphorus & 4.9 & 8.7 & 14 \\
\hline Total lead & 11 & 21 & 34 \\
\hline \multicolumn{4}{|c|}{$\begin{array}{c}\text { Percentage of non-CSO total load from } \\
\text { the entire watershed }\end{array}$} \\
\hline & 3.7 & 6.1 & 11 \\
\hline Fecal coliform & 4.4 & 7.9 & 10 \\
\hline Total phosphorus & 1.0 & 1.8 & 2.8 \\
\hline Total lead & 4.1 & 8.1 & 13 \\
\hline
\end{tabular}

\section{Design Year}

Previous analyses of stormwater discharge to the lower Charles River and CSO facilities planning by the MWRA have relied upon a design year ("typical year") and design storms with 3-month and 1-year recurrence intervals. Zarriello and Barlow (2002) reported the non-CSO design-storm discharges and Breault and others (2002) reported the constituent loads associated with these storms. The MWRA will further examine impacts of stormwater quality on the lower Charles River under these design conditions through simulations with a receiving-water model. For this reason, discharge and load estimates are also given for the design year, because they were not provided in the reports described above.

The design-year loads were calculated by simulating runoff with SWMM models previously developed for the lower Charles River Watershed
(Zarriello and Barlow, 2002) and stormwater constituent concentrations as estimated by stepwise regression methods, average stormwater event mean concentrations, and flow-weighted event mean concentrations (Breault and others, 2002). Sharon Ho-Tsay (Metcalf and Eddy, Inc., written commun., 2002) provided the precipitation hyetograph for the design year, which was modified from actual 1992 precipitation data to include a range of storm sizes. These precipitation data were used in the SWMM models to simulate runoff and in the regression equations to estimate constituent concentrations.

Precipitation and other storm characteristics for the design year were found to be generally similar to those observed in the 2000 water year (fig. 11). The design-year and 2000 water-year storm characteristics tended to fall between the median and upper quartile of the long-term (1970-95) characteristics observed at Logan Airport. One exception to this pattern was the storm antecedent dry period. During the design year, the antecedent dry period was near the upper quartile of the long-term data set for the April to August period, while the 2000 water year values were closer to the median of the long-term data set. Longer antecedent dry periods for the design year increase the stormwater constituent concentration calculated by the multivariate regression equations (Breault and others, 2002) relative to concentrations obtained for the long-term median and the 2000 water year. Long antecedent dry periods allow constituent loads to buildup, which allows for greater removal by street sweeping. Hence, the loads removed during the design year by sweeping may be better represented by the upper estimates of the simulated load removed.

Runoff for the design year was simulated for the watershed below Watertown Dam using SWMM (Zarriello and Barlow, 2002) and estimated for the Charles River at Watertown Dam from the ratio of the upper and lower watershed runoff values for the 2000 water year (table 15). A ratio was used to estimate runoff from the upper watershed because the design year relies upon a synthesized hyetograph that precludes use of measured data from nearby Charles River gaging stations. The estimated runoff from the upper watershed for the design year is 15,500 million $\mathrm{ft}^{3}$ or about 92 percent of the total runoff to the lower Charles River. Runoff from the lower watershed during the design year was simulated to be about 1 percent greater than the runoff during the 2000 water year. 
SUSPENDED SOLIDS

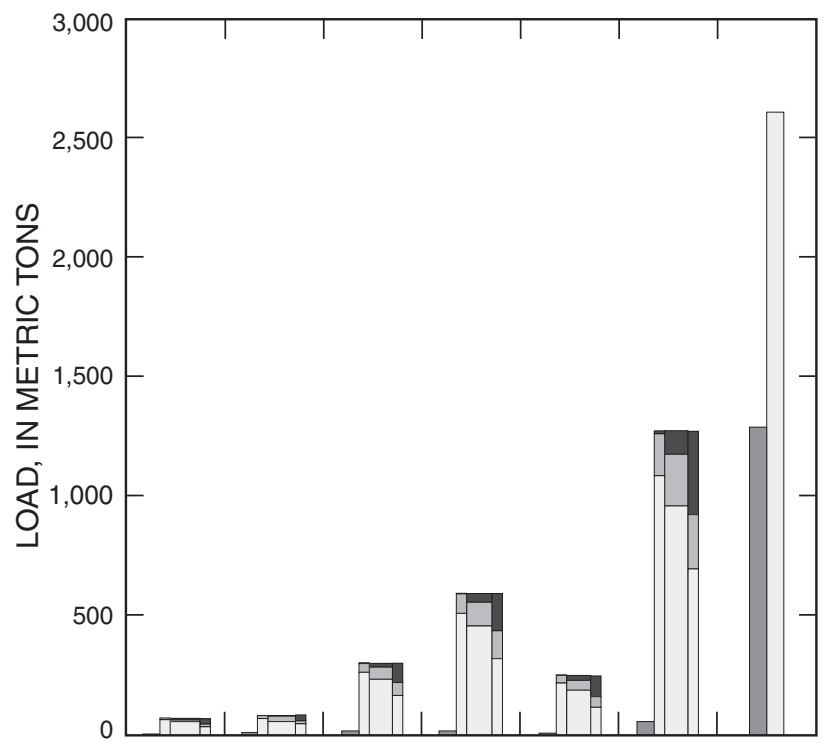

TOTAL PHOSPHORUS

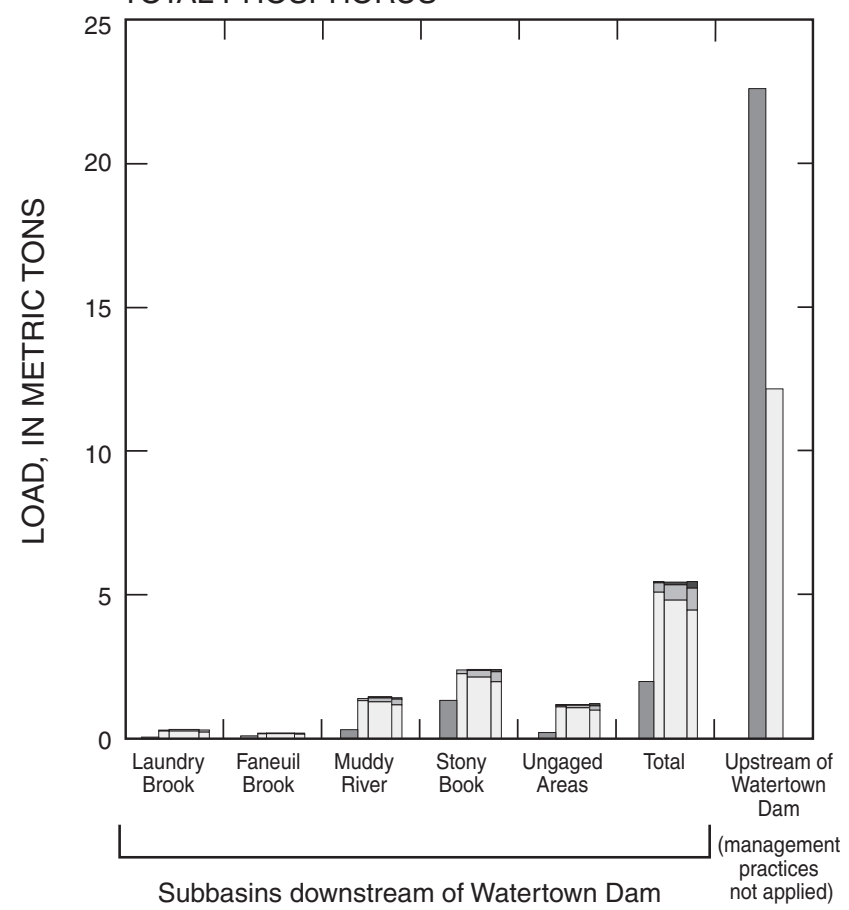

FECAL COLIFORM
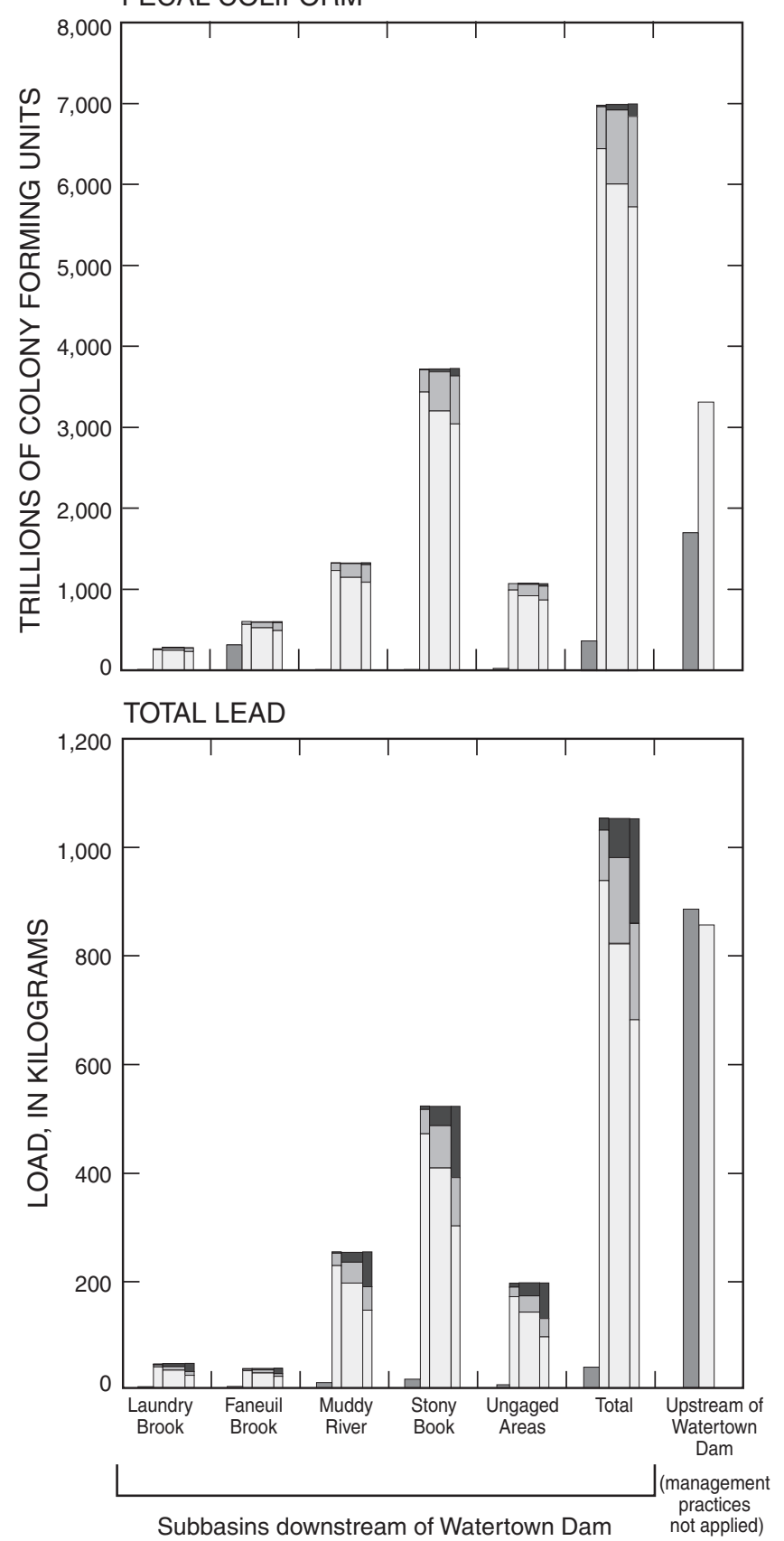

\section{EXPLANATION}

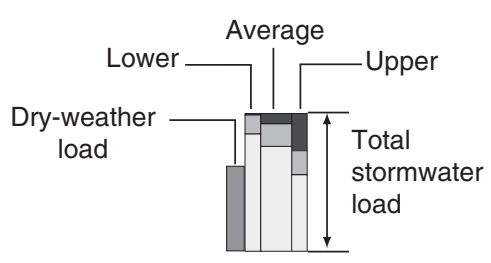

CONSTITUENT LOAD—Estimated lower, average, and upper load removed by combined management practices

Street sweeping

$\square$ Dry-weather load

$\square$ Structural controls

$\square$ Loads remaining after management practices applied

TOTAL - Is the sum of loads from subbasins below Watertown Dam with

Stony Brook before combined sewer separation

Figure 10. Constituent loads from non-combined-sewer-overflow sources from major subbasins, and estimated load reductions by hypothetical structural controls and street sweeping, lower Charles River Watershed, Massachusetts, 2000 water year (unadjusted loads from Breault and others, 2002). 


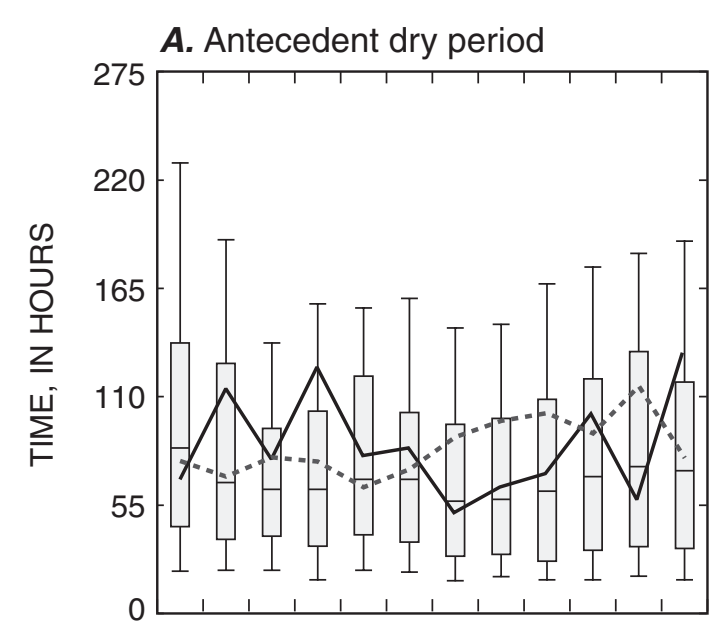

B. Storm duration

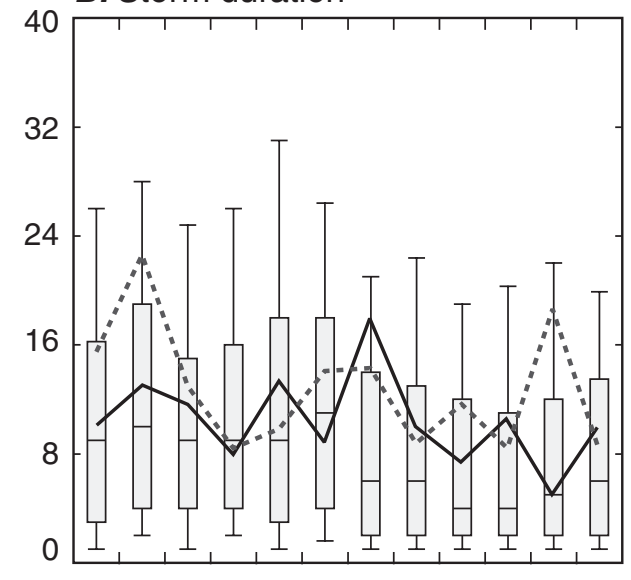

C. Average rainfall intensity

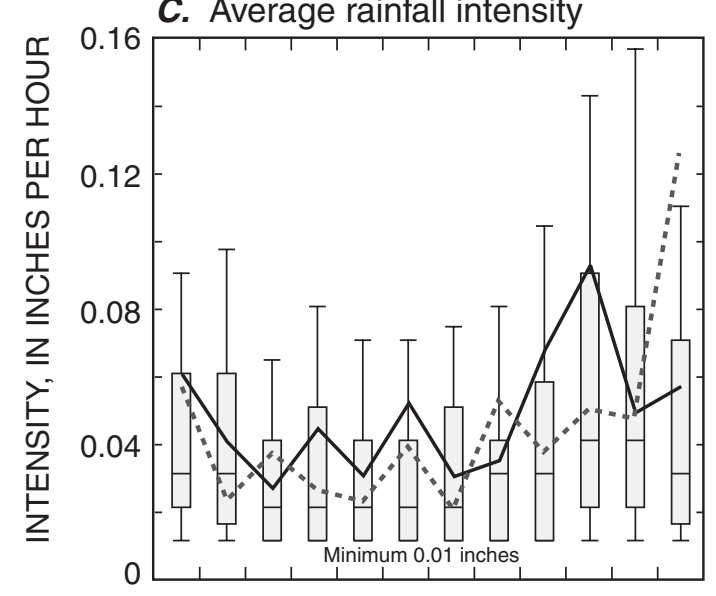

E. Total rainfall

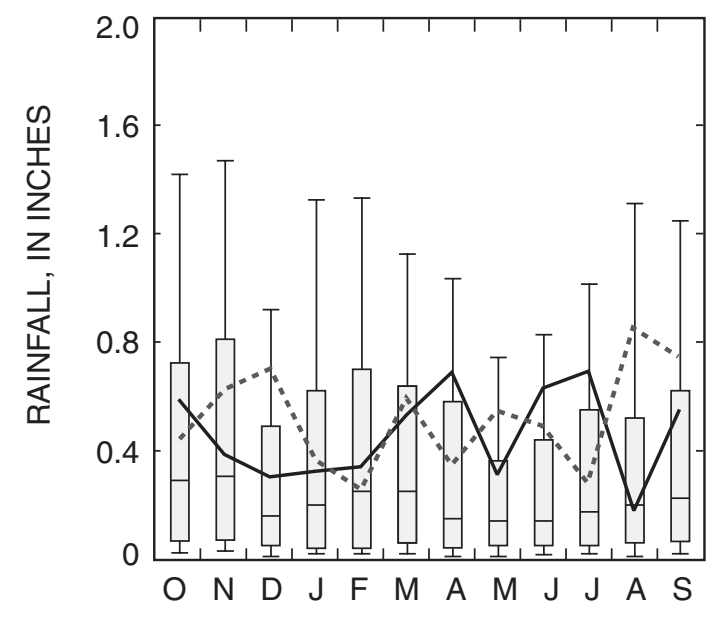

D. Maximum rainfall intensity

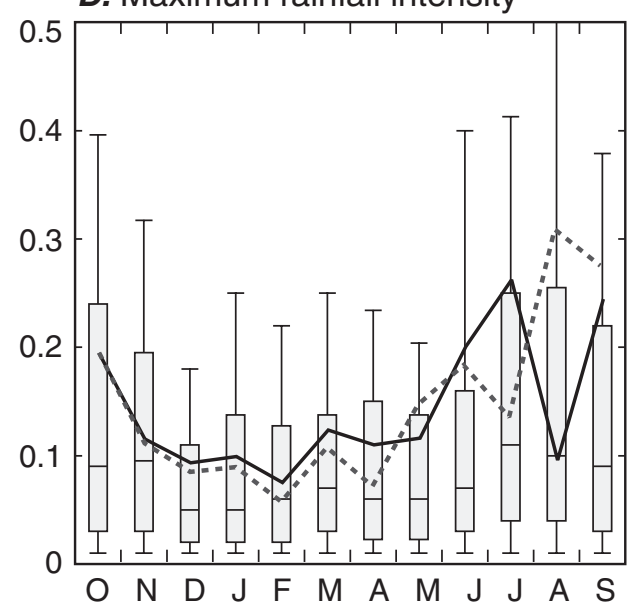

EXPLANATION

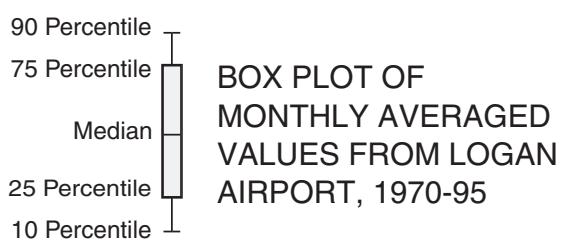

MONTHLY AVERAGED

VALUES FROM SIX GAGES IN THE LOWER CHARLES RIVER WATERSHED, 2000 WATER

.....- MONTHLY AVERAGED VALUES FOR DESIGN YEAR

Figure 11. Distribution of rainfall and antecedent storm characteristics for the 2000 water year, design year, and 1970-95 period, lower Charles River Watershed, Massachusetts. 
Table 15. Simulated runoff volume for the 2000 water year and the design year, lower Charles River Watershed, Massachusetts

\begin{tabular}{|c|c|c|c|}
\hline \multirow[b]{2}{*}{ Site } & \multicolumn{3}{|c|}{$\begin{array}{c}\text { Runoff volume } \\
\text { (millions of cubic feet) }\end{array}$} \\
\hline & $\begin{array}{l}2000 \\
\text { water } \\
\text { year }\end{array}$ & $\begin{array}{l}\text { Design } \\
\text { year }\end{array}$ & $\begin{array}{c}\text { Percent } \\
\text { difference }\end{array}$ \\
\hline & 82.3 & 80.3 & -2.4 \\
\hline Faneuil Brook & 49.1 & 44.5 & -9.4 \\
\hline \multirow{3}{*}{ Stony Brook } & 340 & 337 & 1.0 \\
\hline & 489 & 523 & 7.0 \\
\hline & 284 & 275 & -3.2 \\
\hline Upper watershed & 15,300 & ${ }^{2} 15,500$ & 1.2 \\
\hline
\end{tabular}

The largest source of runoff to the lower Charles River (excluding the upper watershed) was Stony Brook, which contributed 42 percent of the inflow. The Muddy River and the ungaged areas contributed about equal proportions of runoff (about 27 and 22 percent, respectively). Laundry Brook contributed about 6 percent and Faneuil Brook contributed about 3 percent of the total runoff during the design year, excluding inflow from the upper watershed.

Design-year wet- and dry-weather runoff volumes from the upper watershed were estimated from the ratio of wet- to dry-weather runoff volumes observed in the 2000 water year. The volumes obtained were then multiplied by the appropriate EMC and a constant to obtain constituent loads. Stony Brook loads, which reflect conditions during the 2000 water year, include CSO loads. Constituent loads estimated for the design year (table 16) are generally similar to the loads estimated for the 2000 water year reported by Breault and others (2002). The design-year loads were generally slightly larger than the 2000 water-year loads at Laundry Brook and Stony Brook and slightly smaller at Faneuil Brook and Muddy River. Differences between the design-year loads and the 2000 water-year loads were generally largest for loads estimated by the regression method. Percent load reductions that could be expected by implementing structural controls and street sweeping are assumed to be the same for the design year as for the 2000 water-year reductions shown in table 14.

\section{Design Storms}

Design storms with approximately 3-month and 1-year recurrence intervals were selected by MWRA to evaluate the spatial and temporal effects of CSO and non-CSO contaminant loads on the lower Charles River by simulations with a receiving-water model. Predicted changes in loads resulting from implementation of structural controls and street sweeping will provide alternative boundary conditions for the receivingwater model currently under development by the MWRA. The load reductions by structural controls and street sweeping were assumed to be the same as that reported in table 14 . These practices were estimated to achieve non-CSO contaminant-load reductions, as a percentage of the load below Watertown Dam, of up to 46 and 35 percent for suspended solids and total lead, respectively, and about 20 percent for total phosphorus and fecal coliform bacteria. The estimated lower contaminant-load reductions, as a percentage of the nonCSO sources load below Watertown Dam, ranged from 7 to 15 percent.

The relative contributions of contaminant loads from various sources indicated that loads from nonCSO sources below Watertown Dam are larger than loads from the upper watershed for all constituents and design storms, except for total phosphorus for the 3-month storm (fig. 12). Fecal coliform bacteria loads were estimated to be about 2.5 times larger from nonCSO sources below Watertown Dam than from sources upstream of the dam, under present conditions. The combined load reductions from structural controls and street sweeping indicated that these practices could achieve load reductions for suspended solids and total lead that would result in comparable loads for these constituents from the upper and lower watersheds.

The planned sewer separation project in the Stony Brook Subbasin is anticipated to cause a large decrease in the annual volume of CSO discharge and a slight increase in the non-CSO stormwater discharge (Donald Walker, Metcalf \& Eddy, Inc., written commun., November 13, 2001). These changes are expected to cause slight increases in the loads of suspended solids and total lead, due to the increased volume of storm runoff after sewer separation and the comparable concentration of these constituents in storm runoff and CSO discharge. Annual fecal coliform bacteria loads from Stony Brook are expected to decrease by about 33 percent after sewer separation, on the basis of data from the 2000 water year (Breault 
and others, 2002). Decreases in fecal coliform bacteria loads from the 3-month and 1-year design storms after separation are expected to be somewhat less (22 and 23 percent, respectively). Because Stony Brook contributes about 61 percent of the annual stormwater load of fecal coliform bacteria to the lower Charles River (excluding upstream sources), sewer separation is expected to produce an overall decline of 20 percent in the stormwater load of fecal coliform bacteria entering the lower Charles River.

Table 16. Estimated design-year constituent loads from non-combined-sewer-overflow sources for each of the major subbasins to the lower Charles River, Massachusetts

[TCFU, trillion colony-forming units; --, means regression model was not a good predictor of constituent concentration]

\begin{tabular}{|c|c|c|c|c|}
\hline Site & $\begin{array}{l}\text { Suspended solids } \\
\text { (metric tons) }\end{array}$ & $\begin{array}{l}\text { Fecal coliform } \\
\text { (TCFU) }\end{array}$ & $\begin{array}{l}\text { Total phosphorus } \\
\text { (kilograms) }\end{array}$ & $\begin{array}{c}\text { Total lead } \\
\text { (kilograms) }\end{array}$ \\
\hline \multicolumn{5}{|c|}{ Stormwater loads calculated from stepwise regression concentrations } \\
\hline & 84.1 & 189 & 383 & -- \\
\hline Faneuil Brook & -- & 368 & 165 & -- \\
\hline Muddy River & -- & 881 & -- & 310 \\
\hline Stony Brook ${ }^{1}$ & 756 & 3,070 & 2,660 & 691 \\
\hline Ungaged area & 291 & 771 & 1,440 & 247 \\
\hline \multicolumn{5}{|c|}{ Stormwater loads calculated from average event mean concentration } \\
\hline & 1,460 & 5,690 & 13,800 & 696 \\
\hline Laundry Brook & 73.5 & 354 & 363 & 52.6 \\
\hline Faneuil Brook & 83.5 & 586 & 206 & 38.1 \\
\hline Muddy River & 270 & 1,210 & 1,480 & 204 \\
\hline Stony Brook ${ }^{1}$ & 835 & 5,060 & 3,380 & 750 \\
\hline Ungaged area & 267 & 1,250 & 1,390 & 196 \\
\hline \multicolumn{5}{|c|}{ Stormwater loads calculated from flow weighted event mean concentration } \\
\hline & 54.4 & 366 & 262 & 39.1 \\
\hline Faneuil Brook & 60.2 & 621 & 161 & 28.4 \\
\hline Muddy River & 314 & 1,380 & 1,260 & 204 \\
\hline Stony Brook ${ }^{1}$ & 490 & 2,670 & 2,030 & 430 \\
\hline Ungaged area & 250 & 1,350 & 1,090 & 170 \\
\hline \multicolumn{5}{|c|}{ Stormwater loads after sewer separation } \\
\hline - & 885 & 3,050 & 2,820 & 815 \\
\hline \multicolumn{5}{|c|}{ Dry-weather loads calculated from average dry-weather mean concentration } \\
\hline & 1,280 & 1,730 & 23,300 & 899 \\
\hline Laundry Brook & 1.71 & 11.5 & 54.4 & 1.38 \\
\hline Faneuil Brook & 8.89 & 262 & 74.7 & 2.48 \\
\hline Muddy River & 17.3 & 14.5 & 307 & 11.3 \\
\hline Stony Brook ${ }^{1}$ & 17.0 & 3.30 & 1,280 & 16.2 \\
\hline Ungaged area & 6.56 & 16.7 & 143 & 4.58 \\
\hline
\end{tabular}

\footnotetext{
${ }^{1}$ Stony Brook loads are prior to sewer separation
}

${ }^{2}$ Loads for Stony Brook after sewer separation reflect decreases in CSO discharge volume and increases in stormwater-discharge volume; runoff volumes after sewer separation were provided by Metcalf and Eddy, Inc. (written commun., Nov. 13, 2001). 
A.
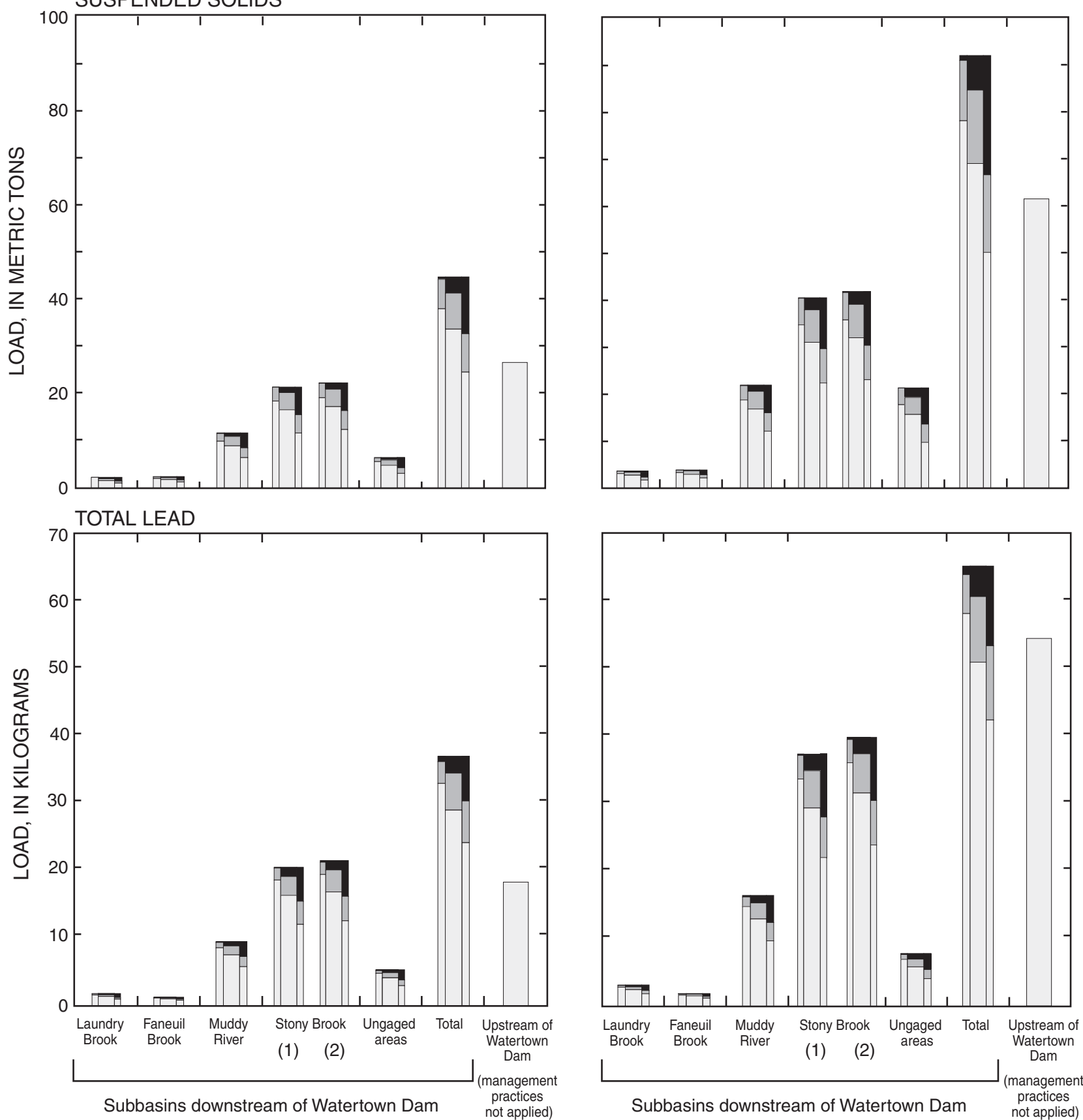

\section{EXPLANATION}

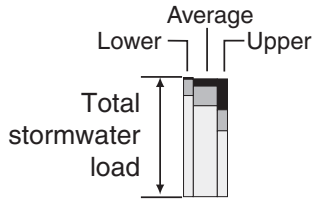

CONSTITUENT LOAD—Estimated lower, average, and upper load removed by combined management practices

- Street sweeping

$\square$ Structural controls

$\square$ Loads remaining after management practices applied

TOTAL_-Is the sum of loads from subbasins below Watertown Dam with Stony Brook before combined sewer separation

\section{STONY BROOK}

(1) Load before combined sewer separation

(2) Load after combined sewer separation

Figure 12. Estimated 3-month and 1-year design-storm loads from non-combined-sewer-overflow sources from each of the major subbasins and estimated load reductions by hypothetical structural controls and street sweeping for $(A)$ suspended solids and total lead loads and $(B)$ fecal coliform and total phosphorus. 
B.
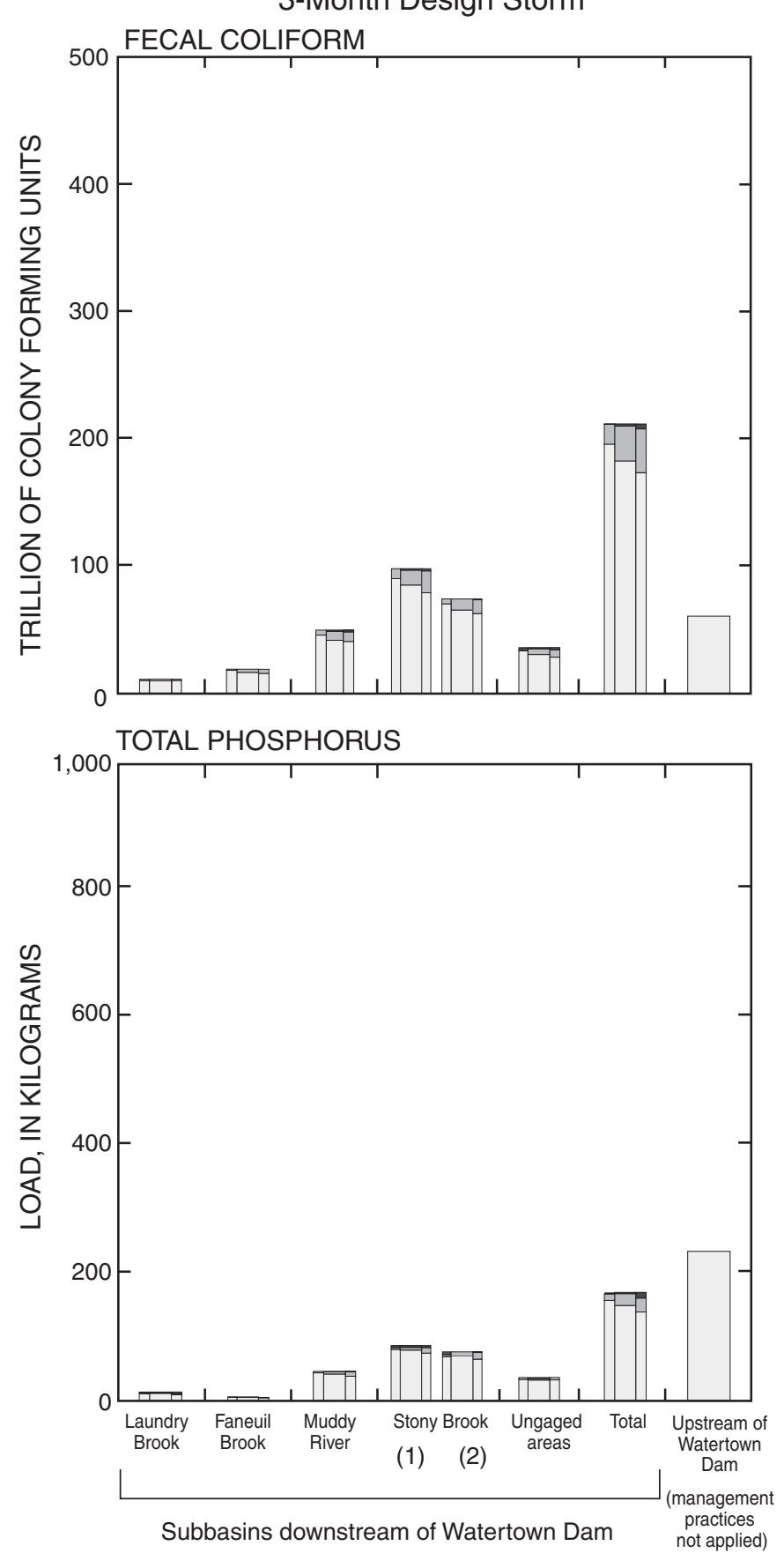

1-Year Design Storm
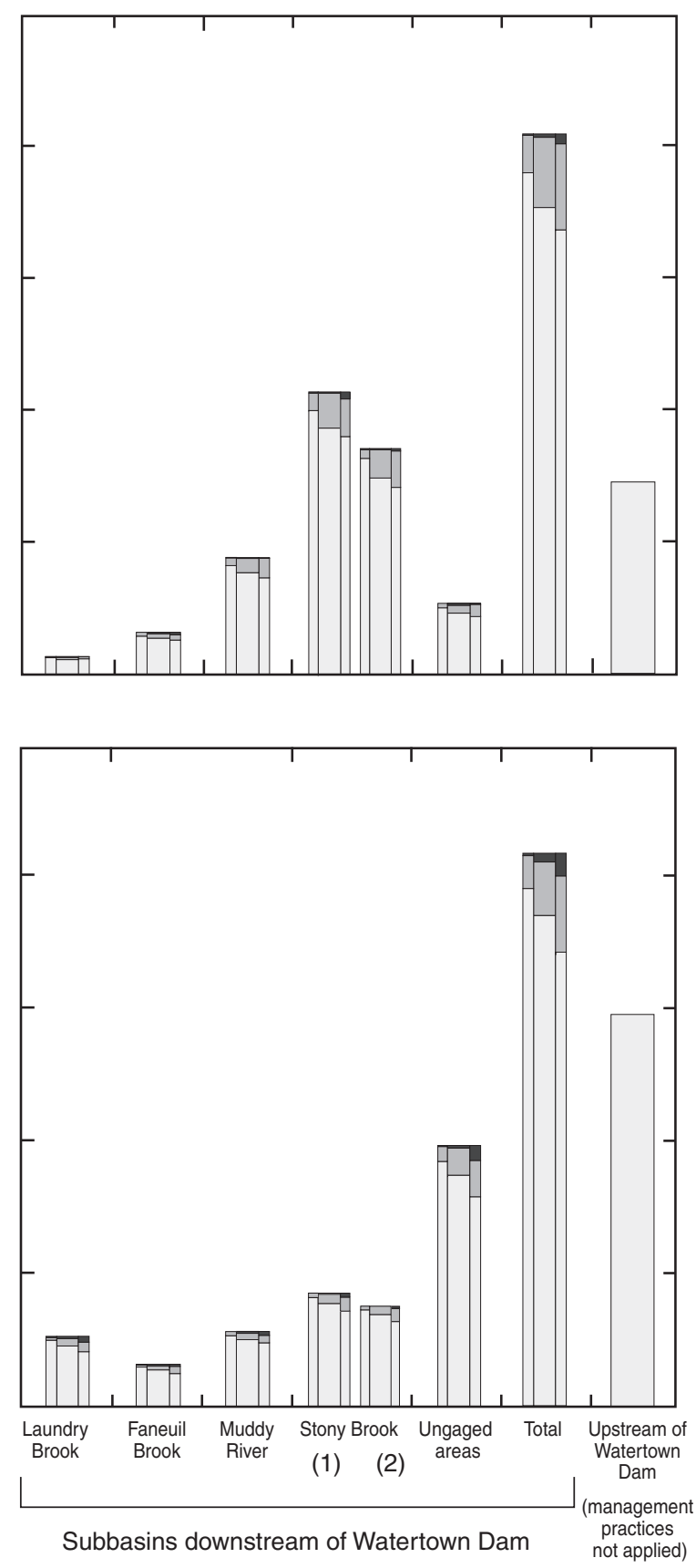

\section{EXPLANATION}

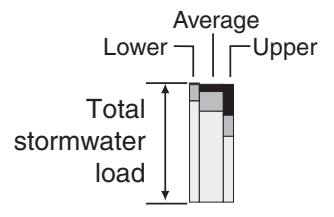

CONSTITUENT LOAD—Estimated lower, average, and upper load removed by combined management practices

- Street sweeping

Structural controls

Loads remaining after management practices applied

TOTAL-Is the sum of loads from subbasins below Watertown Dam with Stony Brook before combined sewer separation

STONY BROOK

(1) Load before combined sewer separation

(2) Load after combined sewer separation

Figure 12. Estimated 3-month and 1-year design-storm loads from non-combined-sewer-overflow sources from each of the major subbasins and estimated load reductions by hypothetical structural controls and street sweeping for $(A)$ suspended solids and total lead loads and $(B)$ fecal coliform and total phosphorus-Continued. 


\section{SUMMARY AND CONCLUSIONS}

The lower Charles River is an important recreational asset to Boston and its surrounding communities. At times its use is impaired because of contaminant loads from stormwater runoff. The goal of making the river fishable and swimmable will likely require a variety of management actions, including control of non-CSO stormwater loads. This study examined the potential reductions in non-CSO stormwater loads that could be achieved by implementing best management practices. Practices examined as part of this study included structural controls identified by the Center for Watershed Protection as suitable for the lower Charles River Watershed and street sweeping. The constituents considered in this study (suspended solids, fecal coliform bacteria, total phosphorus, and total lead) are representative of classes of contaminants that pose a concern for urban water and sediment quality.

Structural controls were grouped by similar major physical or chemical process; these included infiltration-filtration (physical separation), biofiltration-bioretention (biological mechanisms), or detention-retention (physical settling). For each of these categories removal efficiencies were compiled from three national databases of structural-control performance. Of the constituents examined, suspended solids were the most consistently and efficiently removed; efficiencies ranged from -170 to nearly 100 percent and averaged 45 to 78 percent, among control categories. Removal efficiencies for fecal coliform bacteria were the least reported, most variable, and the least effectively removed of the constituents examined; efficiencies ranged from -600 to 99 percent among control categories. Average removal efficiencies for fecal coliform bacteria for infiltration-filtration and detention-retention controls were about 32 and 43 percent, respectively, whereas biofiltration-bioretention controls had an average removal efficiency of -3 percent. Removal efficiencies for total phosphorus ranged from -162 to 100 percent and averaged from 32 to 56 percent among control types. Removal efficiencies for total lead were similar to those reported for suspended solids; efficiencies ranged from -162 to 100 percent and averaged 34 to 66 percent among control types. Average removal efficiencies were generally greatest for infiltration-filtration-type controls and least for biofiltration-bioretention-type controls.
Street sweeping as a water-quality management practice has received renewed interest because of reported improvements in sweeper technology and the recognition that opportunities for implementing structural controls are limited in highly urbanized areas. Streets are known to be a major source of stormwater contaminants; hence, street sweeping merits close examination as a stormwater best management practice. The SWMM model that was developed by the U.S. Geological Survey for the single-family land-use basin of the lower Charles River Watershed was modified to simulate constituent buildup, washoff, and the effects of street sweeping. Constituent buildup and washoff variables were calibrated to annual-load estimates and measured storm loads. Once calibrated, street sweeping was applied for the various permutations of four sweeper efficiencies and six sweeping frequencies. The sweeper efficiencies reflect the types of sweepers currently in use. Sweeping frequencies ranged from once every day to once every 30 days.

Simulations generally indicate that less than 10 percent of the built-up suspended solids and total lead and less than 5 percent of the built-up fecal coliform bacteria and total phosphorus were removed by street sweeping at frequencies of seven days or longer. The percentage of the built-up load removed by sweeping increases markedly at sweeping frequencies shorter than 7 days, particularly for suspended solids and total lead. Simulation results suggest that sweeping, even with the best available technology (effective sweeper efficiencies of 76 percent for suspended solids and total lead and 72 percent for fecal coliform bacteria and total phosphorus), removes only a small fraction of the total load unless intensive sweeping programs are implemented.

Simulated load reductions by street sweeping are highly sensitive to the washoff-variable value, which largely controls the removal of built-up contaminants during storms. Higher values of this variable removed less of the built-up load during small storms, which resulted in more contaminant load available for sweeping. An alternative model with lower washoff-variable values increased loads removed by street sweeping by about threefold for suspended solids, twofold for total lead, 40 percent for total phosphorus, and 20 percent for fecal coliform bacteria. The alternative-model storm loads had a slightly better fit with measured storm loads during the later summer months; thus, the buildup and washoff represented by the alternative 
model could better represent these processes during this period, which results in improved simulated removal rates by street sweeping.

Reduction of constituent loads to the lower Charles River by the combination of hypothetical structural controls and street sweeping was estimated for a range of performance estimates. Ranges of constituent-load reductions were computed rather than a single value because of the inherent variability and uncertainty of removal efficiencies, and because a range provides reasonable bounds on the load that could be removed by the practices under consideration. Upper estimates of combined-load reductions (sweeping once weekly with the best available technology and upper quartile of load removal by structural controls) as a percentage of the non-CSO sources load below Watertown Dam were 44 percent for suspended solids, 34 percent for total lead, 14 percent for total phosphorus, and 17 percent for fecal coliform bacteria. The lowest estimates of combined load reduction (sweeping once monthly with low efficiency sweepers and the lower quartile of load removal by structural controls) as a percentage of the total non-CSO load entering the lower Charles River downstream of Watertown Dam were 14 percent for suspended solids, 11 percent for total lead, 4.9 percent for total phosphorus, and 7.5 percent for fecal coliform bacteria. Load reductions by these combined management practices, however, can be as small as 1.4 percent for total phosphorus to about 4 percent for the other constituents examined when the entire watershed load is considered (includes the load above Watertown Dam).

Although the reductions in stormwater loads to the lower Charles River by the management practices examined appear to be minor when considered on an annual basis over the entire lower Charles River Watershed, the potential water-quality benefits to be gained from these practices cannot be discounted. During and shortly following storms, these practices could provide water-quality benefits in the immediate vicinity of stormwater outfalls. Furthermore, the load reductions by structural controls and street sweeping are highly variable and depend, in part, upon processes that are not well understood. With respect to street sweeping in particular, only direct investigations of contaminant buildup, washoff, and sweeping processes, and controlled studies of sweeping effects on stormwater loads, will provide definitive evidence of the water-quality benefits that these practices can provide to the lower Charles River and other urban waterways.

\section{REFERENCES}

American Society of Civil Engineers, 2002, National Stormwater Best Management Practices Database, accessed on the World Wide Web on February 18, 2002, at URL http://www.asce.org/community/ waterresources/nsbmpdb.cfm.

Athayde, D.N., Shelly, P.E., Driscoll, E.D., Gaboury, D., and Boyd, G., 1983, Results of the nationwide urban runoff program-volume 1-final report: U.S. Environmental Protection Agency, WH-554, $186 \mathrm{p}$.

Baldys, Stanley, III, Raines, T.H., Mansfield, B.L., and Sandlin, J.T., 1998, Urban stormwater quality, event-mean concentrations, and estimates of stormwater pollutant loads, Dallas-Fort Worth area, Texas, 1992-93: U.S. Geological Survey Water-Resources Investigations Report 98-4158, $51 \mathrm{p}$.

Ball, J.E., Jenks, Rebecca, and Aubourg, David, 1996, Dry weather build-up of constituents on road surfaces: Hanover, Germany, $7^{\text {th }}$ international conference on urban storm drainage, p. 785-790.

Bannerman, R.T., 1999, Sweeping water clean: American Sweeper Magazine, v. 7, no. 1., 4 p.

Bannerman, R.T., Owens, D.W., Dodds, R.B., and Hornewer, N.J., 1993, Sources of pollutants in Wisconsin stormwater: Water Science Technology, v. 28 , no. $3-5$, p. 241-259.

Bender, G.M., and Terstriep, M.L., 1984, Effectiveness of street sweeping in urban runoff pollution control: Science of the Total Environment, v. 33, p. 185-192.

Bent, G.C., Gray, J.R., Smith, K.P., and Glysson, G.D., 2001, A synopsis of technical issues for monitoring sediment in highway and urban runoff: U.S. Geological Survey Open-File Report 01-497, $51 \mathrm{p}$.

Breault R.F., and Granato, G.E., 2000, A synopsis of technical issues of concern for monitoring trace elements in highway and urban runoff: U.S. Geological Survey Open-File Report 00-422, 67 p. 
Breault, R.F., Sorenson, J.R., and Weiskel, P.K., 2002, Streamflow, water quality and contaminant loads in the lower Charles River Watershed, Massachusetts, 1999-2000: U.S. Geological Survey Water-Resources Investigations Report 024137, $131 \mathrm{p}$.

Bricker, O.P., 1999, An overview of the factors involved in evaluating the geochemical effects of highway runoff on the environment: U.S. Geological Survey Open-File Report 98-630, 28 p.

Brown, W., and Schueler, T., 1997, National pollutant removal performance database for stormwater best management practices: Center for Watershed Protection, $371 \mathrm{p}$.

Buckler, D.R., and Granato, G.E., 1999, Assessing the biological effects from highway-runoff constituents; U.S. Geological Survey Open-File Report 99-240, 45 p.

Burnhart, Matt, (undated), Sources of bacteria in Wisconsin stormwater: Madison, WI, Wisconsin Department of Natural Resources, 34 p.

Center for Watershed Protection, 1999, Lower Charles River Basin Retrofit Inventory: Ellicott City, MD, Center for Watershed Protection, variously paged.

Colman, J.A., Rice, K.C., and Willoughby, T.C., 2001, Methodology and significance of studies of atmospheric deposition in highway runoff: U.S. Geological Survey Open-File Report 01-259, 63 p.

Camp Dresser \& McKee, Larry Walker Associates, Uribe and Associates, Resources Planning Associates, 1993. California Stormwater Best Management Practice Municipal HandbookBMP: Street Cleaning, p. 4-64-4-66.

Finely, Stuart, 2000, Virginia tests further documents pickup of high efficiency sweepers: American Sweeper Magazine, v. 8, no. 1, 4 p.

Granato, G.E., 2001, National highway runoff waterquality data and methodology synthesis, accessed March 11, 2002, at URL http://ma.water.usgs.gov/ FHWA.

Gray, J.R., Glysson, D.G., Turcois, L.M., and Schwarz, G.E., 2000, Comparability of suspended-sediment concentrations and total suspended solids data: U.S. Geological Survey Water-Resources Investigations Report 00-4191, 20 p.

Horner, R.R., Skupien, J.J., Livingtston, E.H., and Shaver, H.E., 1994, Fundamentals of urban runoff management-Technical and institutional issues: Washington, DC, Terrene Institute, 302 p.
Huber, W.C., and Dickinson, R.E., 1992, Storm water management model (Version 4)-User's manual: Athens, GA, U.S. Environmental Protection Agency, USEPA/600/3-88/001a, 595 p.

Massachusetts Water Resources Authority, 1994, Baseline water quality assessment: unpublished report by Metcalf and Eddy, Inc., variously paged.

Northern Virginia Planning District Commission, 1992, Northern Virginia BMP handbook, A guide to planning and designing best management practices in Northern Virginia: Annandale, VA, Northern Virginia Planning District Commission and Engineers and Surveyors Institute, 302 p.

Pitt, Robert, 1978, Potential of street cleaning in reducing nonpoint pollution: Proceedings of the Urban Hydrology, Hydraulics, and Sediment Control Symposia, University of Kentucky, p. 289-302.

Pitt, Robert, 1985, Characterization and controlling urban runoff through street and sewerage cleaning: U.S. Environmental Protection Agency Report USEPA/600/2-85/038, 467 p.

Pitt, Robert, and Bozeman, Martin, 1980, Water quality biological effects of urban runoff on Coyote Creek-Phase I, preliminary survey: U.S. Environmental Protection Agency, USEPA-600/280-104, 73 p.

Pitt, Robert, Field, Richard, Lalor, Melinda, and Brown, Michael, 1995, Urban stormwater toxic pollutants-Assessment, sources and treatability: Water Environment Research, v. 67, no. 3, p. 260 275.

Pritchett, H.S., Mansfield, S.M., and Dana, R.H., 1903, Report of the committee on the Charles River Dam: Boston, MA, Resolves of 1901, chap. 105, Write and Potter Printing, $579 \mathrm{p}$.

Sansalone, J.J., Buchberger, S.G., and Koechling, M.T., 1995, Correlations between heavy metals and suspended solids in highway runoff-implications for control strategies: Washington, D.C., Transportation Research Record 1483, p. 112-119.

Sartor, J.D., Boyd, G.B., and Agardy, G.F., 1972, Water pollution aspects of street surface contaminants: Atlanta, GA, Proceedings of the $45^{\text {th }}$ annual conference of the Water Pollution Control Federation, October, 26 p. 
Sartor, J.D., and Boyd, G.B., 1972, Water pollution aspects of street surface contaminants:

Washington, DC, U.S. Environmental Protection Agency, USEPAR2-72-081 (NTIS PB-214408), $237 \mathrm{p}$.

Sartor, J.D., and Boyd, G.B., 1975, Water quality improvement through control of road surface runoff, in water pollution control in low density areas: Hanover, $\mathrm{NH}$, Proceedings of a Rural Environmental Engineering Conference, p. 301316.

Sartor, J.D., and Gaboury, D.R., 1984, Street sweeping as a pollution control measure-Lessons learned over the past ten years: Science of the Total Environment, v. 33, p. 171-183.

Schueler, T.R., 1987, Controlling urban runoff-A practical manual for planning and redesigning urban BMPs: Washington, DC, Prepared for the Washington Metropolitan Water Resources Planning Board, no. 87703, p. 1.1-9.19.

Shoemaker, Leslie, Lahlou, Mohammed, Doll, Amy, and Cazenas, Patricia, 2000, Stormwater best management practices in an ultra-urban settingSelection of monitoring: Federal Highway Administration, FHWA-EP-00-002, 287 p.

Smith, D.L., and Lord, B.M., 1990, Highway water quality control-Summary of 15 years of research: Washington, DC, Transportation Research Record 1279, p. 69-74.

Smith, K.P., 2002, The effectiveness of three best management practices along the Southeast Expressway, Boston, Massachusetts: U.S. Geological Survey Water-Resource Investigations Report 02-4059, 62 p.

Steuer, J.J., Selbig, W.R., Hornewer, N.J., and Prey, Jeffrey, 1997, Sources of contamination in an urban basin in Marquette, Michigan and an analysis of concentrations, loads, and data quality: U.S. Geological Survey Water-Resources Investigations Report 97-4242, 25 p.

Sutherland, R.C., and Jelen, S.L., 1997, Contrary to conventional wisdom, street sweeping can be an effective BMP, in James, William, ed., Advances in Modeling the Management of Stormwater Impacts-Volume 5: Guelph, Canada, CHI, p. 179-190.
Tasker, G.D., and Granato, G.E., 2000, Statistical approaches to interpretation of local, regional, and national highway-runoff and urban-stormwater data: U.S. Geological Survey Open-File Report 00-491, $59 \mathrm{p}$.

Terrene Institute, 1998, A clean sweep now possible: Virginia, Runoff Report, The Terrene Institute, v. 6 , no. 4, 4 p.

U.S. Environmental Protection, 1996, State of the New England environment-making Charles River fishable and swimmable by 2005, accessed May 14, 2002, at URL http:// www.epa.gov/NE/soe/charles.html.

2002, Charles River earns a "B" grade for water quality; stormwater pollution and individual action priorities for future improvement, accessed May 14, 2002, at URL http://www.epa.gov/NE/soe/ charles.html.

Waschbusch, R.J., Selbig, W.R., and Bannerman, R.T., 1999, Sources of phosphorus from two urban residential basins in Madison, Wisconsin, 199495, U.S. Geological Survey Water-Resources Investigations Report 99-4021, 47 p.

Washington State Dept. of Ecology, 1999, Stormwater Management Manual for Western WashingtonVolume IV: Source Control BMPs, no. 99-14, $149 \mathrm{p}$.

Washington State Department of Transportation, 1995, Highway runoff manual: Washington State Department of Transportation, $197 \mathrm{p}$.

White, E.M., 1981, Possible clay concentrations effects on soluble phosphate contents of runoff: Environmental Science and Technology, v. 15, no.12. p. 1726-1731

Wilde, F.D., 1994, Geochemistry and factors affecting ground-water quality at three storm-watermanagement sites in Maryland: Annapolis, Maryland Geological Survey Report of Investigations, no. 59, $201 \mathrm{p}$.

Young, G. K., Stein, S., Cole, P., Kammer, T., Graziano, F., and Bank F., 1996, Evaluation and management of highway runoff water quality: Federal Highway Administration publication no. FHWA-PD-96-032, 457 p.

Zarriello, P.J., and Barlow, L.K., 2002, Measured and simulated runoff to the lower Charles River, Massachusetts, October 1999-September 2000: U.S. Geological Survey Water-Resources Investigations Report 02-4129, 89 p. 